This document was prepared in conjunction with work accomplished under Contract No.

DE-AC09-96SR18500 with the U.S. Department of Energy.

\title{
DISCLAIMER
}

This report was prepared as an account of work sponsored by an agency of the United States Government. Neither the United States Government nor any agency thereof, nor any of their employees, makes any warranty, express or implied, or assumes any legal liability or responsibility for the accuracy, completeness, or usefulness of any information, apparatus, product or process disclosed, or represents that its use would not infringe privately owned rights. Reference herein to any specific commercial product, process or service by trade name, trademark, manufacturer, or otherwise does not necessarily constitute or imply its endorsement, recommendation, or favoring by the United States Government or any agency

thereof. The views and opinions of authors expressed herein do not necessarily state or reflect those of the United States Government or any agency thereof.

This report has been reproduced directly from the best available copy.

Available for sale to the public, in paper, from: U.S. Department of Commerce, National Technical Information Service, 5285 Port Royal Road, Springfield, VA 22161, phone: (800)

553-6847, fax: (703) 605-6900, email: orders@ntis.fedworld.gov online ordering: http://www.ntis.gov/ordering.htm

Available electronically at http://www.doe.gov/bridge

Available for a processing fee to U.S. Department of Energy and its contractors, in paper, from: U.S. Department of Energy, Office of Scientific and Technical Information, P.O. Box 62, Oak Ridge, TN 37831-0062, phone: (865 ) 576-8401, fax: (865) 576-5728, email: reports@ adonis.osti.gov 
WSRC-TR-2000-00319

SRT-RPP-2000-00020

\title{
Milestone M4900: Simulant Mixing Analytical Results
}

\author{
UNCLASSIFIED \\ DOES NOT CONTAIN \\ UNCLASSIFIED CONTROLLED \\ NUCLEAR INFORMATION \\ ADC \& \\ Reviewing \\ Official: \\ (Name and Title) \\ Date:
}

Westinghouse Savannah River Company

Savannah River Site

Aiken, SC 29808

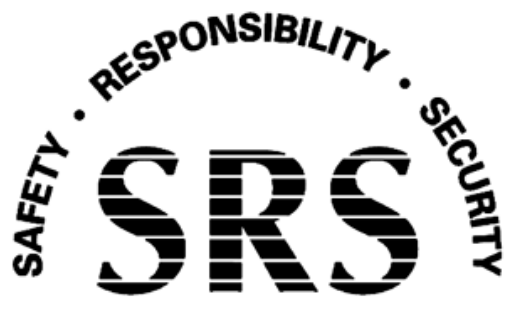

Prepared for the U.S. Department of Energy under Contract No. DE-AC09-96SR18500 
WSRC-TR-2000-00319

SRT-RPP-2000-00020

KEYWORDS:

Hanford River Protection Project

\section{Milestone M4900: Simulant Mixing Analytical Results}

SAVANNAH RIVER TECHNOLOGY CENTER

D. I. Kaplan

R. E. Eibling

D. J. McCabe

January 10,2000

Westinghouse Savannah River Company

Savannah River Site

Aiken, SC 29808

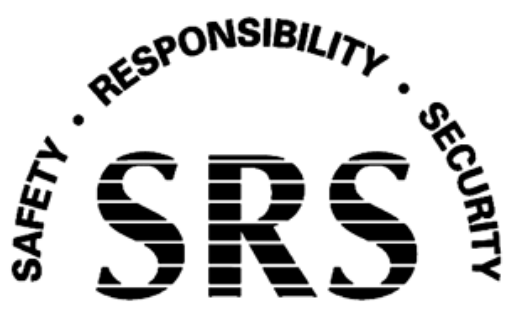

Prepared for the U.S. Department of Energy under Contract No. DE-AC09-96SR18500 
DOCUMENT: $\quad$ WSRC-TR-2000-00319 (SRT-RPP-2000-00020)

TITLE: $\quad$ Milestone M4900: Simulant Mixing Analytical Results

\section{APPROVALS}

Date:

Daniel Kaplan (WPT/SRTC)

Date:

Russell Eibling (IT/SRTC)

Date:

Daniel McCabe (WPT/SRTC)

Date:

Steven Wach, RPP Pretreatment Manager

Date:

Major Thompson, Technical Reviewer (AT/SRTC) 
WSRC-TR-2000-00319

SRT-RPP-2000-00020

Revision 0

\section{SUMMARY}

This report addresses Milestone M4900, "Simulant Mixing Sample Analysis Results," and contains the data generated during the "Mixing of Process Heels, Process Solutions, and Recycle Streams: Small-Scale Simulant" task. The Technical and Quality Assurance Plan for this task is BNF-003-98-0079A.

The overall objective of this small-scale simulant mixing study was to identify the processes that generate precipitates and to identify the precipitates formed. Four experiments were conducted to address the specific items identified in the test specifications (Johnson 1999). The four experiments were:

1. Dilution Experiment: quantify and characterize the precipitates formed by diluting simulants with $0.01 \mathrm{M} \mathrm{NaOH}$

2. Envelope Mixing Experiment: quantify and characterize the precipitates formed by mixing simulants

3. Hydroxide-Concentration Experiment: quantify and characterize the precipitates formed by adding or partially neutralizing the free hydroxide in simulants

4. Envelope-D Leachate Mixing Experiment: quantify and characterize the precipitates formed by mixing AZ-102 caustic leachate simulant or C-106 caustic leachate simulant (both nominally $3 \mathrm{M} \mathrm{NaOH}$ ) with various feed simulants

Briefly, the simulants were made and monitored for turbidity. Once turbidity stabilized, indicating a steady state may have been reached, the simulants were filtered and used in mixing studies. The simulants were than treated by dilution, mixing, $\mathrm{HNO}_{3}$ addition, or caustic leachate addition. Turbidity and temperature was measured for 1 to 2 months after treatment. After this period of monitoring turbidity and temperature, the suspensions were filtered and the resulting aqueous and solid phases were characterized. The aqueous phase was analyzed for total organic and inorganic carbon, free hydroxides (titration), metals (Inductively Coupled Plasma - Emission Spectroscopy; ICP-ES), CI and $\mathrm{F}^{-}$(Ion Selective Electrode; ISE), anions (Ion Chromatography; IC), formate, glycolate, acetate, and oxalate (Ion Exchange Chromatography; IEC), and EDTA/HEDTA (Ion Paired Chromatography; IPC). Solids were analyzed by X-ray Diffraction (XRD) to identify crystalline phases, and Energy Dispersive X-ray Analysis/Scanning Electron Microscopy (EDX/SEM) to measure the chemical composition and morphology of amorphous solid phases. This report includes the analytical results from these studies. A report with a narrative description and discussion of this data and OLI thermodynamic modeling will be issued separately. 
WSRC-TR-2000-00319

SRT-RPP-2000-00020

Revision 0

\section{TABLE OF CONTENTS}

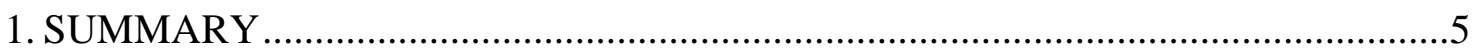

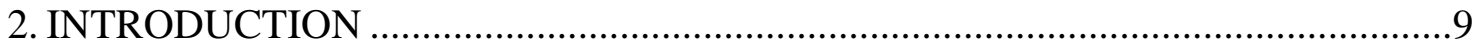

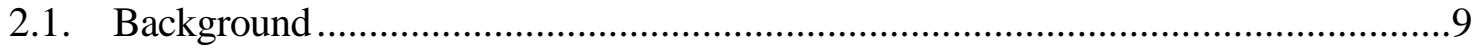

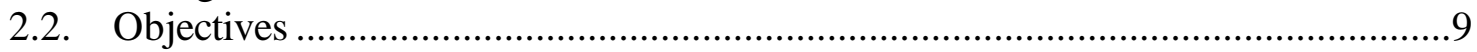

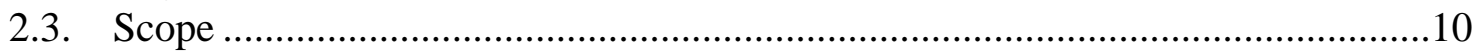

2.4. General Approach...................................................................................11

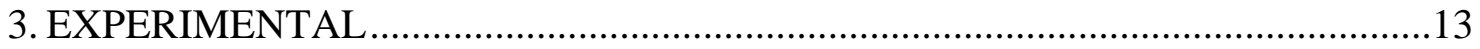

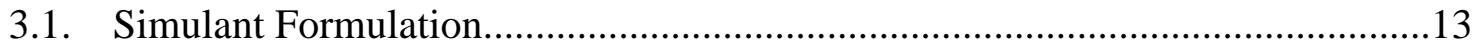

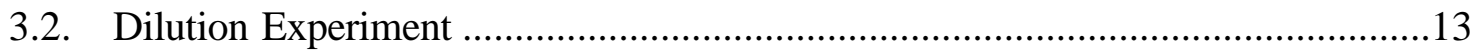

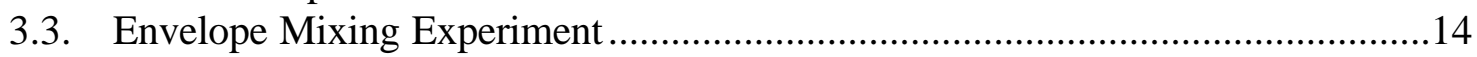

3.4. Hydroxide-Concentration Experiment ..................................................................14

3.5. Envelope-D Leachate Mixing Experiment .........................................................15

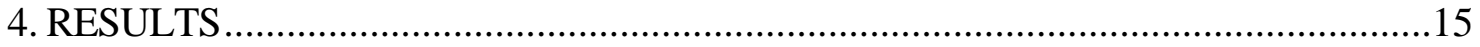

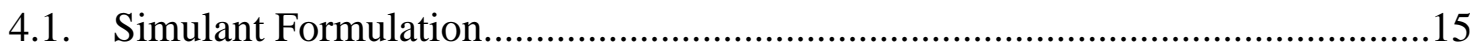

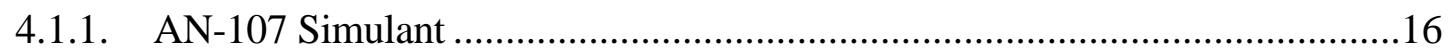

4.1.2. AW-101 Simulant ................................................................................22

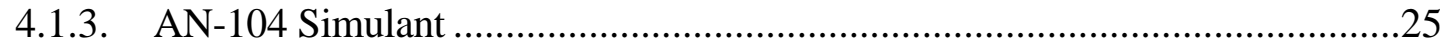

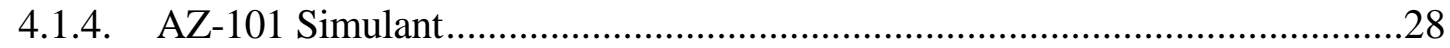

4.1.5. AZ-102 Simulant ...................................................................................

4.1.6. C-106 Caustic Leachate Simulant.................................................................33

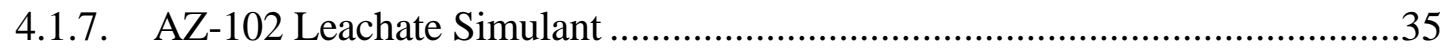

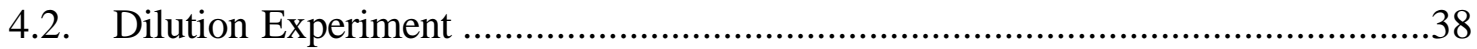

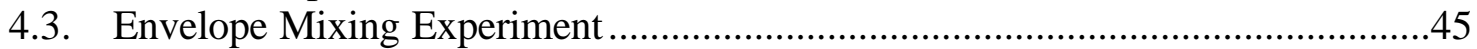

4.3.1. Full-strength Envelope Mixing Experiment ……………………………....47

4.3.2. Dilute Envelope Mixing Experiment …………………………….................50

4.4. Hydroxide-Concentration Experiment ................................................................57

4.4.1. Titration Basis for $\mathrm{pH}$ Adjustment............................................................57

4.4.2. pH Adjustment of AN-107 Simulant ........................................................60

4.4.3. pH Adjustment of AN-104 Simulant ...........................................................65

4.4.4. pH Adjustment of AW-101 Simulant ............................................................69

4.4.5. $\mathrm{pH}$ Adjustment of AZ-101 Simulant .............................................................73

4.4.6. $\mathrm{pH}$ Adjustment of AZ-102 Simulant.............................................................

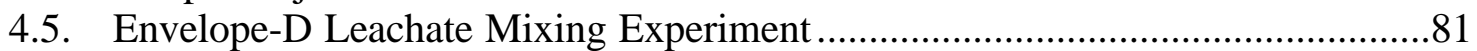

4.5.1. AN-107 and C-106 Caustic Leachate Mixtures............................................82

4.5.2. A and B Envelopes Mixed with Caustic Leachates ........................................84

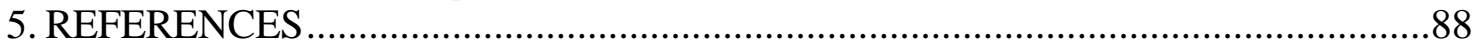

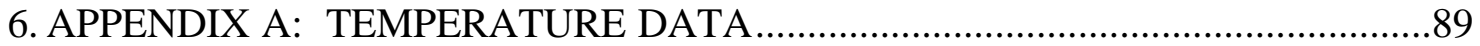

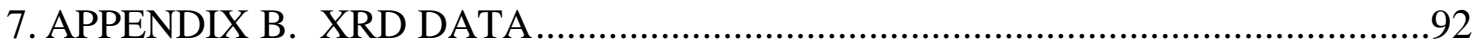

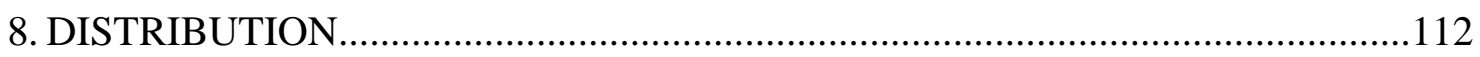




\section{LIST OF FIGURES}

Figure 1. Simulant Turbidity (NTU) During Equilibration Period Prior to Mixing.........16

Figure 2. Turbidity of AN-104 Diluted with $0.01 \mathrm{M} \mathrm{NaOH}$..........................................39

Figure 3. Turbidity of AW-101 Diluted with $0.01 \mathrm{M} \mathrm{NaOH}$...........................................40

Figure 4. Turbidity of AZ-101 Diluted with $0.01 \mathrm{M} \mathrm{NaOH}$..........................................41

Figure 5. Turbidity of AZ-102 Diluted with $0.01 \mathrm{M} \mathrm{NaOH}$...........................................42

Figure 6. Turbidity of AN-107 Diluted with $0.01 \mathrm{M} \mathrm{NaOH}$..........................................43

Figure 7. Turbidity and Solid Phases Based on XRD and SEM in Mixtures of AZ-101 and $\mathrm{AN}-107$.

Figure 8. SEM image and EDX spectrum of solids recovered at the end of the 50\% AZ$101 / 50 \%$ AN-107 mixtures. The scale bar in the SEM image represents 32.4- $\mu \mathrm{m}$. The EDX spot size was about the same as the entire SEM image, thus it represents an average.

Figure 9. Turbidity and solid phases based on XRD and SEM in Mixtures of AN-107 and $\mathrm{AN}-104$.

Figure 10. Turbidity in Dilute AN-107, Dilute AN-104, and a 9\% AN-107 \& 91\% AN104 Mixture.

Figure 11. Turbidity in Dilute AN-107, Dilute AW-101, and a 9\% AN-107 \& 91\% AW101 Mixture.

Figure 12. Mixture of Dilute AN-107 and Dilute AZ-102............................................55

Figure 13. SEM image and corresponding EDX spectra of 9\% dilute AN-107 / 91\% dilute AN-104. Spot 1 is an EDX spectrum taken of large amorphous particles. Spot 2 is an EDX spectrum taken of crystalline particles. A third EDX spectrum is presented of a large spot size, which provides an average elemental composition of

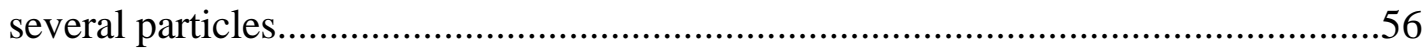

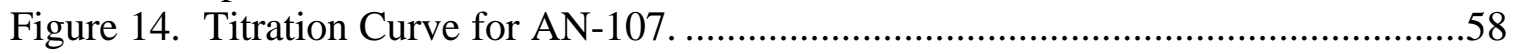

Figure 15. Titration Curve for AN-104 ................................................................58

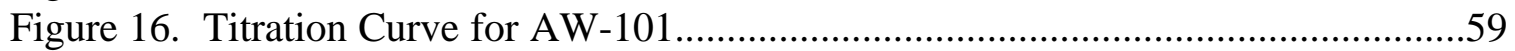

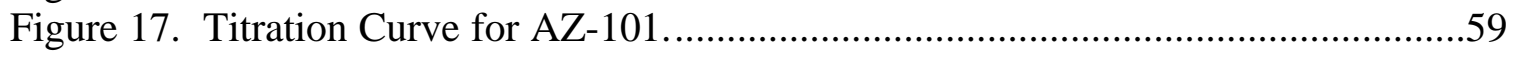

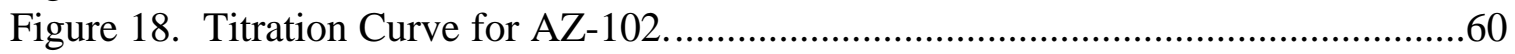

Figure 19. Turbidity of pH-Adjusted AN-107 Simulant. ...............................................63

Figure 20. AN-107 pH-Adjusted Simulant.............................................................63

Figure 24. Turbidity of pH-Adjusted AN-104 Simulant. ..............................................68

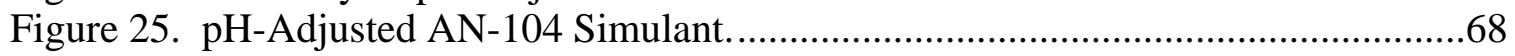

Figure 28. Turbidity of pH-Adjusted AW-101 Simulant...................................................72

Figure 31. Turbidity of pH-Adjusted AZ-101 Simulant.................................................76

Figure 34. Turbidity of pH-Adjusted AZ-102 Simulant.................................................80

Figure 37. Turbidity of AN-107 \& C-106 Leachate Simulant Mixtures...........................82

Figure 38. Turbidity of AW-101 \& C-106 Leachate Simulant Mixtures. .........................84

Figure 39. Turbidity of AZ-102 \& AZ-102 Leachate Mixtures. ......................................85

Figure 40. Turbidity of AZ-101 and AZ-102 Leachate Mixtures......................................86

Figure 41. Turbidity of AN-104 and C-106 Leachate Mixtures......................................87 


\section{LIST OF TABLES}

Table 1. Experimental Treatment Factorial.

Table 2. Some Causes Responsible for Differences Between Planned and Found

Concentrations of Analytes in Simulant Feeds.......................................................18

Table 3. AN-107 Simulant Feed Composition. …………................................................

Table 4. AN-107 Simulant Feed Organic Composition.....................................................22

Table 5. AW-101 Simulant Feed Composition.............................................................24

Table 6. AN-104 Simulant Feed Composition. ………….............................................27

Table 7. AZ-101 Simulant Feed Composition................................................................29

Table 8. AZ-102 Simulant Feed Composition...................................................................32

Table 9. Tank C-106 Caustic Leachate Simulant Feed Composition................................34

Table 10. AZ-102 Caustic Leachate Simulant Composition. ............................................37

Table 11. Turbidity and Solids Concentrations (Collected on a 0.45-Micron Filter) At the

End of the 60-Day Equilibration Period. ................................................................44

Table 12. Chemical Composition of Selected Filtrates from Envelope Mixing Study:

ICP-ES (mg/L).

Table 13. Chemical Composition of Selected Filtrates from Envelope Mixing Study:

Other Methods (mg/L) .................................................................................46

Table 16. Active and Simulant Feed Sodium Concentrations..........................................50

Table 17. Simulant Dilutions for Dilute Envelope Mixing Study....................................50

Table 18. Chemical Composition of Selected Filtrates from Dilute Envelope Mixing

Study: ICP-ES (mg/L) ......................................................................................51

Table 19. Chemical Composition of Selected Filtrates from Dilute Envelope Mixing

Study: Other Methods $(\mathrm{mg} / \mathrm{L})$..........................................................................52

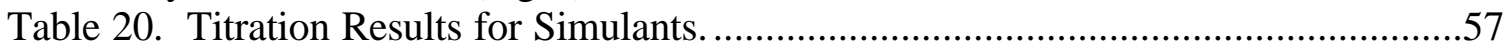

Table 21. Based on Preliminary Titration Experiments, Amount of Nitric Acid (70 \%) or

Sodium Hydroxide (50 wt-\%) Required to Adjust $\mathrm{pH}$ of Simulants........................60

Table 22. Composition of pH-Adjusted AN-107 Simulant. ............................................62

Table 23. Summary of pH Adjusted AN-107 Observations..............................................64

Table 24. Composition of pH-Adjusted AN-104 Simulant. ..............................................67

Table 25 Summary of pH-Adjusted AN-104 Observations................................................69

Table 26. pH Adjustment Results for AW-101 Simulant..............................................71

Table 27. Summary of pH Adjusted AW-101 Observations...........................................73

Table 28. Composition of pH-Adjusted AZ-101 Simulant...............................................75

Table 29. Summary of pH Adjusted AZ-101 Observations. .............................................77

Table 30. Composition of pH-Adjusted AZ-102 Simulant..............................................79

Table 31. Summary of pH Adjusted AZ-102 Observations. ..............................................

Table 32. Composition of 50:50 Mixture of AN-107 and C-106 Leachate.......................83 
WSRC-TR-2000-00319

SRT-RPP-2000-00020

Revision 0

\section{INTRODUCTION}

\subsection{Background}

This report addresses Milestone M4900, "Simulant Mixing Sample Analysis Results," and contains the data generated during the "Mixing of Process Heels, Process Solutions, and Recycle Streams: Small-Scale Simulant" task. The Task Technical and Quality Assurance Plan for this task is BNF-003-98-0079A. A report with a narrative description and discussion of the data will be issued separately. A brief description of the objectives, scope and general approaches follow. The data are organized by the experiments conducted for this task.

\subsection{Objectives}

The overall objective of this small-scale simulant mixing study was to identify the processes that generate precipitates and to identify the types of precipitates formed. Four experiments were conducted to address the specific items identified in the test specifications (Johnson 1999). The four experiments were:

1. Dilution Experiment: quantify and characterize the precipitates formed by diluting simulants with $0.01 \mathrm{M} \mathrm{NaOH}$. Candidate Low-Activity Waste (LAW) feed solutions may need to be diluted with $0.01 \mathrm{M} \mathrm{NaOH}$ solution prior to transfer to the River Protection Project - Waste Treatment Plant (RPP-WTP) in order to meet pipeline transfer conditions. Candidate LAW feed solutions may need to be further diluted with $0.01 \mathrm{M} \mathrm{NaOH}$ solution after receipt at the RPP-WTP to comply with flowsheet process conditions. This set of dilution tests is intended to mimic the postulated dilution of the LAW solutions.

2. Envelope Mixing Experiment: quantify and characterize the precipitates formed by mixing simulants. Candidate LAW feed solutions will be mixed with various process solutions within the RPP-WTP. These mixing experiments are intended to address the potential range of these mixtures as identified in the RPP-WTP flowsheet.

3. Hydroxide-Concentration Experiment: quantify and characterize the precipitates formed by adding or partially neutralizing the free hydroxide in simulants with nitric acid. Candidate LAW feed solutions will be mixed with various process solutions within the RPP-WTP. These hydroxide concentration experiments mimic mixing acidic or neutral waste solutions with the LAW feed solution, to address the potential range of these mixtures as identified in the RPP-WTP flowsheet. 
4. Envelope-D Leachate Mixing Experiment: quantify and characterize the precipitates formed by mixing AZ-102 caustic leachate $(3 \mathrm{M} \mathrm{NaOH})$ simulant and C-106 caustic leachate $(3 \mathrm{M} \mathrm{NaOH})$ simulant with various feed simulants. Candidate LAW feed solutions will be mixed with various process solutions within the RPP-WTP. These experiments mimic mixing the caustic leachate from pretreatment of High-Level Waste (HLW) solids with the LAW feed solutions, to address the potential range of these mixtures as identified in the RPP-WTP flowsheet.

\subsection{Scope}

The following simulant feed solutions were used in each experiment:
AN-104 (Envelope A), AW-101 (Envelope A), AZ-101 (Envelope B), AZ-102 (Envelope B), and AN-107 (Envelope C).

Although the initial plan was to use an AN-105 simulant, AN-105 simulant was not used in these studies because its chemical composition is very similar to that of AN-104 (Herting 1997, Herting 1998). The technical basis for each simulant composition is provided in the Results section entitled "Simulant Formation." It is anticipated that AN102 (Envelope C) will be processed in the near future. ${ }^{1}$ However, it was not included in

\footnotetext{
${ }^{1}$ The TWRS Privatization contract specifies in clause H.9 a LAW feed sequence based on metric tons of sodium in each feed envelope. Michael Johnson (now of $\mathrm{CH} 2 \mathrm{M}$ Hill Hanford Group) provided information obtained from Russ Treat (Lockheed Martin Hanford Co.), Rudy Carreon (DOE-ORP) and Joe Cruz (DOEORP) concerning the LAW feed sequence. The resulting feed sequence plan follows (personal communication).
}

FY2000 multi-year work plan guidance will direct the PHMC to plan on the following sequence. AZ-101 or AZ-102 (the order of these two tanks is not set) will be the first wastes treated. These two tanks will be transferred to BNFL without dilution and processed first. The pretreated LAW will be evaporated in accordance with specification 11 and stored in three (or four) of six new 250,000 gallon tanks constructed and operated by BNFL Inc. BNFL will receive AN-102 (no dilution) as the next LAW feed. After processing AN-102, BNFL will receive AN-104 as the next feed (which may possibly need dilution to $10 \mathrm{M}$ Na for transfer). After processing AN-104, BNFL will receive AN-107 (no dilution) as the next feed. The sequence of AN-102 and AN-107 may be switched, depending on the difficulty of waste retrieval. AN-104 will probably remain in this sequence in order to demonstrate processing an Envelope C waste early and AN-104 needs to be emptied to receive cross-site transfer wastes.

Since the initiation of this study, additional guidance regarding the order in which the tank waste will be treated has been released (letter number 00-OPD-013 dated January 26, 2000, from R. T. French, DOE Office of River Protection, to M. P. DeLozier, President and General Manager, CH2M Hill Hanford Group, Inc.). A summary of this letter by Eric Slaathaug (CH2M Hill Hanford Group) follows. 
WSRC-TR-2000-00319

SRT-RPP-2000-00020

Revision 0

this study because, at the time of this study, insufficient tank-waste characterization data was available to create a simulant recipe. The Envelope D leachate recipe used in the Envelope-D Leachate Mixing Experiment was based on $3 \mathrm{M} \mathrm{NaOH}$ leaching of AZ-102 and C-106 solids samples (Herting 1995, Brooks 1997).

The experiments did not include radioactive isotopes and did not address the problem of mixing the envelopes with off-gas condensates from HLW and LAW melters. Laboratory testing of this problem was deferred until more characterization information of the two off-gas condensate streams is available.

Savannah River Technology Center (SRTC) personnel undertook these modifications to the test plan after consultation and approval by the RPP-WTP technical representative for this task.

\subsection{General Approach}

The experimental treatments evaluated in this study are presented in Table 1. Briefly, the simulants were made and monitored for turbidity. Once turbidity stabilized, indicating a steady state may have been reached, the simulants were filtered and used in mixing studies. The filtered simulants were treated as outlined in Table 1. Turbidity and temperature were monitored for 1 to 2 months after treatment. After this monitoring period, the suspensions were filtered and the resulting aqueous and solid phases were characterized. The aqueous phase was analyzed for total organic and inorganic carbon (TOC, TIC), free hydroxides (titration), metals by Inductively Coupled Plasma -

Emission Spectroscopy (ICP-ES), CI and $\mathrm{F}^{-}$by Ion Selective Electrodes (ISE), anions by Ion Chromatography (IC), formate, glycolate, acetate, and oxalate by Ion Exclusion Chromatography (IEC), and EDTA, HEDTA by Ion Pair Chromatography (IPC). Solids were analyzed by X-ray Diffraction (XRD) to identify crystalline phases, and Energy Dispersive X-ray Spectroscopy/Scanning Electron Microscope (EDX/SEM) to measure the chemical composition and identify the morphology of amorphous solid phases. Each series of experiments included the monitoring of turbidity and temperature for the unaltered simulant to provide a baseline for solids formed.

Tank AP-101 was designated as the first LAW feed to the WTP, followed by AZ-101, AZ-102, AN-102, AN-104, AN-107 and AP-104/SY-101. The pretreated AZ-101 and AZ-102 wastes are no longer evaporated and stored. The pretreated AZ-101 and AZ-102 waste are vitrified concurrent with pretreatment facility operations. 
Table 1. Experimental Treatment Factorial.

\begin{tabular}{|c|c|}
\hline Experiment & Treatment \\
\hline \multirow[t]{5}{*}{ Dilution $^{\mathrm{a}}$} & $10,50,90,100 \%$ AN-104 \\
\hline & $10,50,90,100 \% \mathrm{AW}-101$ \\
\hline & $10,50,90,100 \%$ AZ-101 \\
\hline & $10,50,90,100 \%$ AZ-102 \\
\hline & $10,50,90,100 \%$ AN-107 \\
\hline \multirow[t]{2}{*}{ Envelope Mixing } & $\begin{array}{l}0 \% \text { AZ-101/100\% AN-107, 10\% AZ-101/90\% AN-107, 50\% AZ- } \\
101 / 50 \% \text { AN-107, and 0\% AZ-101/100\% AN-107 }\end{array}$ \\
\hline & $\begin{array}{l}0 \% \text { AN-107 /100\% AN-104, 10\% AN-107 /90\% AN-104, 50\% AN- } \\
107 / 50 \% \text { AN-104, and 0\% AN-107 /100\% AN-104 }\end{array}$ \\
\hline \multirow[t]{5}{*}{ Hydroxide Conc. } & $\mathrm{pH} \sim 10, \sim 11, \sim 13, \sim 14.5 \mathrm{AN}-104$ \\
\hline & $\mathrm{pH} \sim 10, \sim 11, \sim 13, \sim 14.5 \mathrm{AW}-101$ \\
\hline & $\mathrm{pH} \sim 10, \sim 11, \sim 13, \sim 14.5 \mathrm{AZ}-101$ \\
\hline & $\mathrm{pH} \sim 10, \sim 11, \sim 13, \sim 14.5 \mathrm{AZ}-102$ \\
\hline & $\mathrm{pH} \sim 10, \sim 11, \sim 13, \sim 14.5 \mathrm{AN}-107$ \\
\hline \multirow[t]{5}{*}{ Env. D Leachate } & $\begin{array}{l}0 \% \mathrm{AN}-104 / 100 \% \mathrm{C}-106 \text { leachate, } 10 \% \mathrm{AN}-104 / 90 \% \mathrm{C}-106 \text { leachate, } \\
50 \% \mathrm{AN}-104 / 50 \% \mathrm{C}-106 \text { leachate, } 90 \% \mathrm{AN}-104 / 10 \% \mathrm{C}-106 \text { leachate, } \\
\text { and } 100 \% \mathrm{AN}-104 / 0 \% \text { C-106 leachate }\end{array}$ \\
\hline & $\begin{array}{l}0 \% \text { AW-101/100\% C-106 leachate, } 10 \% \text { AW-101/90\% C-106 } \\
\text { leachate, } 50 \% \text { AW-101/50\% C-106 leachate, } 90 \% \text { AW-101/10\% C- } \\
106 \text { leachate, and } 100 \% \text { AW-101/0\% C-106 leachate }\end{array}$ \\
\hline & $\begin{array}{l}0 \% \text { AZ-101/100\% AZ-102 leachate, } 10 \% \text { AZ-101/90\% AZ-102 } \\
\text { leachate, 50\% AZ-101/50\% AZ-102 leachate, 90\% AZ-101/10\% AZ- } \\
102 \text { leachate, and 100\% AZ-101/0\% AZ-102 leachate }\end{array}$ \\
\hline & $\begin{array}{l}0 \% \text { AZ-102/100\% AZ-102 leachate, } 10 \% \text { AZ-102/90\% AZ-102 } \\
\text { leachate, 50\% AZ-102/50\% AZ-102 leachate, 90\% AZ-102/10\% AZ- } \\
102 \text { leachate, and 100\% AZ-102/0\% AZ-102 leachate }\end{array}$ \\
\hline & $\begin{array}{l}0 \% \mathrm{AN}-107 / 100 \% \mathrm{C}-106 \text { leachate, } 10 \% \mathrm{AN}-107 / 90 \% \mathrm{C}-106 \text { leachate, } \\
50 \% \mathrm{AN}-107 / 50 \% \mathrm{C}-106 \text { leachate, } 90 \% \mathrm{AN}-107 / 10 \% \mathrm{C}-106 \text { leachate, } \\
\text { and } 100 \% \mathrm{AN}-107 / 0 \% \text { C-106 leachate }\end{array}$ \\
\hline
\end{tabular}




\section{EXPERIMENTAL}

\subsection{Simulant Formulation}

1. Five simulant feed solutions, AN-104, AW-101, AZ-101, AZ-102, and AN-107, and two caustic leachate solutions (3-M NaOH), AZ-102 caustic leachate and C-106 caustic leachate simulants were prepared.

2. The solutions were permitted to come to steady state by continuous agitation over night at room temperature.

3. After one day of stirring, the turbidity and temperature of the solutions were measured.

4. The solutions were permitted to equilibrate for another 4 days. At which time, turbidity and temperature of the solutions were measured. If negligible turbidity was detected, then we proceeded to step 5 . If turbidity was detected, then the solutions were filtered through a $0.45-\mu \mathrm{m}$ filter. After the additional equilibration period, the simulant was mixed and the turbidity and temperature were measured. If negligible turbidity was detected, then we proceeded to step 5 . If turbidity was detected, then the solutions were filtered. These cycles of $\geq 2$-day equilibration periods and turbidity monitoring were continued until negligible turbidity was detected.

5. Once steady state was achieved, as defined by turbidity, the simulants were permitted to continue equilibrating for an additional 7-days. After the 7-day equilibration period, turbidity and temperature were measured and the samples were filtered.

Note: Filtration of the prepared simulant solutions and measurement of turbidity were conducted to provide a measure of whether the simulants had reached a steady state. Collection and characterization of the filtrate was not in the scope of this study. The filtration process was not designed to mimic any specific WTP process. Attempts were made to bring the simulants into steady state prior to use in the mixing studies. It is desirable for the solutions to have reached a steady state insofar that it provides a reference state. It is not known whether the solutions in the WPT will in fact exist in a steady state. $\mathrm{pH}$ was not used as indicator of steady state because it is very difficult to measure in high $\mathrm{pH}$ and high ionic strength solutions.

\subsection{Dilution Experiment}

1. The 5-feed simulants (AN-104, AW-101, AZ-101, AZ-102, and AN-107) created as described above were diluted with $0.01 \mathrm{M} \mathrm{NaOH}$ to make $250-\mathrm{mL}$ solutions of 10,50 , 90 , and $100 \%$ (vol.) simulant.

2. The mixtures were permitted to come to steady state by placing on a platform shaker.

3. Turbidity and temperature of the mixtures were measured each workday.

4. After 30 days, a system was assumed to be at steady state once turbidity remained steady for at least four consecutive readings. This equilibration period did not exceed 60 days. 
5. Once steady state was achieved, as defined by turbidity, the mixtures were permitted to continue equilibrating for an additional 7 days.

6. At the end of the equilibration period, turbidity and temperature was measured and then the aqueous and solid phases of the mixtures was separated via $0.45-\mu \mathrm{m}$

filtration. To reduce the risk of dissolving solids, solids collected on the filter were not rinsed with water to remove entrained liquids. Thus, salts formed by evaporation of the liquids may have formed, causing an experimental artifact.

7. Constituents in the aqueous phase of samples that generated large amounts of precipitates were quantified as follows: free hydroxides by strong-acid titration, anions by IC, cations by ICP-AE, and total organic carbon (TOC) by oxidation/IR.

8. For samples with a sufficient amount of solids, XRD analyses were conducted. If identification of the solids was not possible by XRD, than SEM/EDX were also conducted on the samples. Total solids were determined gravimetrically using tared $0.45-\mu \mathrm{m}$ filters.

\subsection{Envelope Mixing Experiment}

1. The following simulants were combined: AZ-101 \& AN-107 and AN-107 \& AN-104. These combinations were selected based on the present understanding of the order in which the waste will be treated (see footnote 1). The simulants were combined to produce mixtures with the following proportions (volume percentages):

- $0 \%$ AZ-101/100\% AN-107, 10\% AZ-101/90\% AN-107, 50\% AZ-101/50\% AN107, and $0 \% \mathrm{AZ}-101 / 100 \% \mathrm{AN}-107$, and

- $0 \%$ AN-107 /100\% AN-104, 10\% AN-107/90\% AN-104, 50\% AN-107/50\% AN104 , and $0 \% \mathrm{AN}-107 / 100 \% \mathrm{AN}-104$

2. -8 . These steps are identical to those in the Dilution Experiment.

\subsection{Hydroxide-Concentration Experiment}

1. The 5-feed simulants (AN-104, AW-101, AZ-101, AZ-102, and AN-107) created as described above were equilibrated with four different volumes of concentrated $\mathrm{HNO}_{3}$ or $\mathrm{NaOH}$. The $\mathrm{HNO}_{3}$ amended solutions had identical volumes of simulant, $0.2 \mathrm{~L}$, and varying volumes of $\mathrm{HNO}_{3}$. The targeted $\mathrm{pH}$ was $10,11,13$, and 14.5. Since $\mathrm{pH}$ is difficult to measure accurately at $\mathrm{pH}>13$ and at high ionic strength, the amount of $\mathrm{HNO}_{3}$ or $\mathrm{NaOH}$ added to each treatment was based on preliminary titration studies using the simulant solutions. The actual $\mathrm{pH}$ values of the $\mathrm{pH}$-adjusted simulants were calculated based on the final aqueous chemistry. The measured $\mathrm{pH}$ values of these solutions and the amount of $\mathrm{HNO}_{3}$ added are discussed in the Results section, section 4.4.1.

2. -8 . These steps are identical to those in the Dilution Experiment. 


\subsection{Envelope-D Leachate Mixing Experiment}

1. The 5 feed simulants (AN-104, AW-101, AZ-101, AZ-102, and AN-107) created as described above were combined with varying amounts of the AZ-102 or C-106 Caustic Leachate simulants to create $0.25 \mathrm{~L}$ solutions containing $0,10,50,90$, and $100 \%$ simulant.

2. -8 . These steps are identical to those in the Dilution Experiment.

\section{RESULTS}

To save a great deal of space, not all the quality control (QC) sample data (blanks, MS, MSD, LCS) for the analytical results were provided. This Quality Control data could be provided upon request. All experiment temperature data is presented in Appendix A and all X-ray Diffraction data is presented in Appendix B.

\subsection{Simulant Formulation}

Simulants were prepared in 6-L batches to represent supernate from five Hanford waste tanks, AN-107, AW-101, AN-104, AZ-101, and AZ-102. Two additional simulants were prepared in 3-L batches to represent the solution obtained by leaching the sludge from tanks C-106 and AZ-102 with 3-M sodium hydroxide. The prepared feed was mixed, filtered, and monitored for turbidity as described in the experimental section. The feed solutions were monitored for periods ranging from 28 to 36 days depending on when a specific feed was prepared. Turbidity (in units of nephelometric turbidity units, NTU's) of the seven solutions during the equilibration period, prior to use in the mixing study, is presented in Figure 1. At the end of the stability period, each simulant was filtered through a 0.45 -micron nylon filter. This filtration process does not mimic any WTP process. The final simulant feeds were therefore filtered at least twice during feed preparation. The final feed simulant was submitted for chemical characterization. The solids removed during the feed equilibration period by filtration were not submitted for analysis. Attempts were made to achieve steady state because this would be a relatively more easily defined state, as compared to some transitory state. It is not known whether actual tank waste will be in a steady state during treatment. The laboratory temperature during the monitoring period was $21.9 \pm 1.3{ }^{\circ} \mathrm{C}$. Specific details about the formulation and turbidity of each feed solution are described below. 


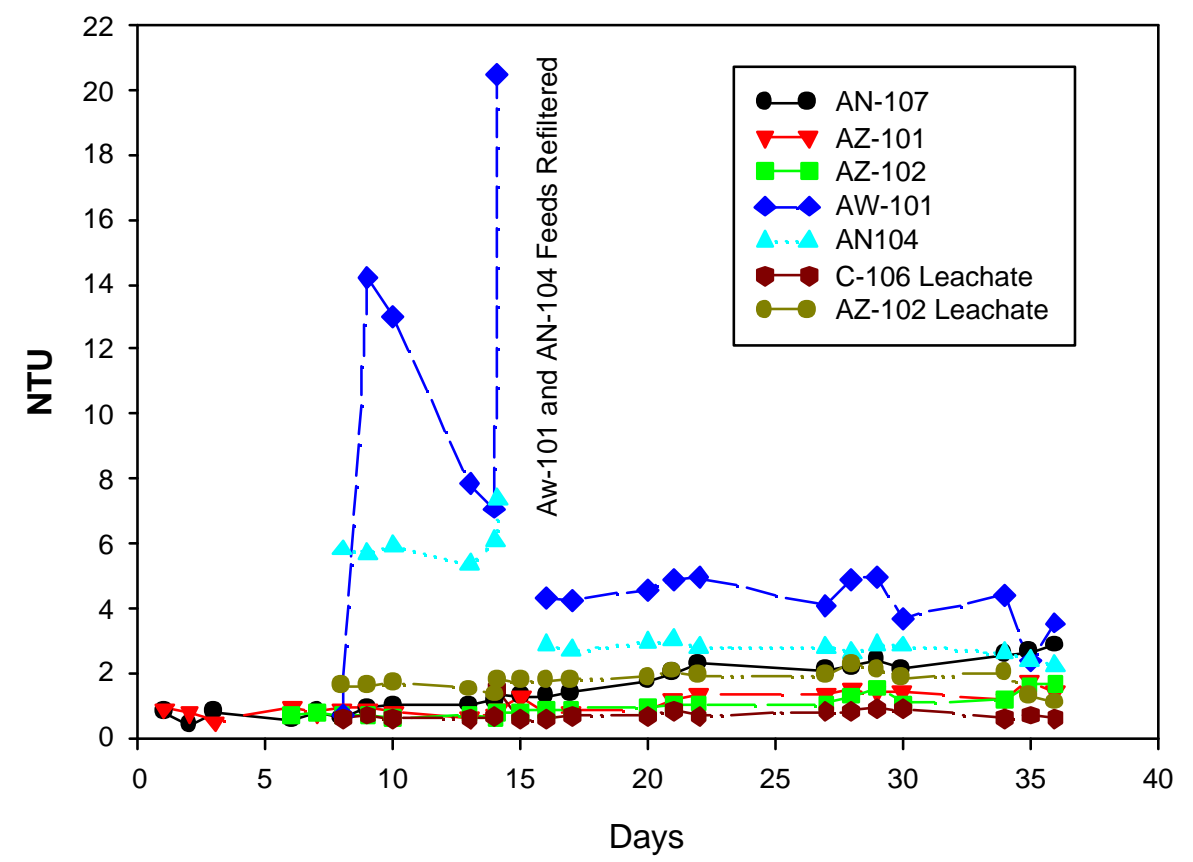

Figure 1. Simulant Turbidity (NTU) During Equilibration Period Prior to Mixing.

\subsection{1. $\quad$ AN-107 Simulant}

AN-107 simulant was based on the undiluted supernate from tank 241-AN-107 and was prepared at 8.8-M sodium. The recipe of this simulant, SRTC Envelope C Simulant, is based on Esch (1997). During the equilibrium period, the AN-107 simulant turbidity slowly increased to about 2.9 NTU. Since this increase was so small and the feed was going to be filtered at the end of the equilibrium stage, the stability period was not extended beyond 36 days. When the AN-107 feed (a brown-colored solution) was filtered, it became apparent that large, tabular crystals had formed at the bottom of the feed container despite the periodic agitation and the extremely low turbidity readings. 
WSRC-TR-2000-00319

SRT-RPP-2000-00020

Revision 0

The crystals were identified by $x$-ray diffraction as thermonatrite, the monohydrate of sodium carbonate $\left(\mathrm{Na}_{2} \mathrm{CO}_{3} \cdot \mathrm{H}_{2} \mathrm{O}\right.$ ) (see Figure B12 in Appendix B). Interestingly, the analyzed composition of the $\mathrm{AN}-107$ simulant did show a $4 \%$ reduction in planned $\mathrm{Na}$ (ICP-ES) and carbonate concentrations.

The planned and as-produced composition of the AN-107 simulant feed is listed in Table 3 and Table 4. The density of the AN-107 simulant feed was $1.403 \mathrm{~g} / \mathrm{mL}$ and the total solids in the simulant measured by microwave drying were $45.5 \%$ (wt.). The produced AN-107 simulant composition was significantly lower (>20\% deviation) in concentration than the planned composition for minor components $\mathrm{Ag}, \mathrm{Ba}, \mathrm{Cd}, \mathrm{Mg}, \mathrm{Sr}, \mathrm{Zr}$, and major components $\mathrm{Al}, \mathrm{Ca}$, oxalate, carbonate (based on titration), and ethylenediaminetetraacetic acid (EDTA). The produced AN-107 simulant composition was significantly greater $(>20 \%)$ in concentration than planned for the minor component Cs and major components $\mathrm{Cl}, \mathrm{F}, \mathrm{PO}_{4}{ }^{3-}$, TOC, $\mathrm{AlO}_{4}$, free $\mathrm{OH}, \mathrm{N}$-(2-hydroxyethyl)ethylenediaminetriacetic acid (HEDTA), and iminodiacetic acid (IDA).

A brief summary for some of the causes that may be responsible for the discrepancies between the planned and found concentrations is presented in Table 2. The larger than expected $\mathrm{F}^{-}$and $\mathrm{Cl}$ anion concentrations in the $\mathrm{AN}-107$ simulant may be related to interference during the ion chromatography (IC) analysis from monovalent organic anions such as formate, acetate and glycolate. The larger than expected aluminate and free hydroxide concentrations may be due to interference from organic anions during the titration analysis. Similarly, the lower than expected carbonate analysis by titration may also be related to interference from the organic anions. The TIC-carbonate concentration found in the $\mathrm{AN}-107$ simulant closely matches the planned but is about $27 \%$ more than that measured by titration, supporting the assumed organic anion interference during titration analysis.

Silver was included as one of the trace metals in the AN-107 simulant, the AN-104 simulant and the AZ-102 simulants. In all three simulants the soluble silver, after the feed stability period was complete, was less than detection limits. Since none of the feeds was protected from light, photoreduction of the aqueous silver cation was the probable mechanism by which the silver target concentration was missed. Given the expected low concentration of silver in the three waste envelopes and the ease of reduction, the absence of silver from the tested solutions should not have any impact on the goal of the experiments. 
Table 2. Some Causes Responsible for Differences Between Planned and Found Concentrations of Analytes in Simulant Feeds.

\begin{tabular}{|c|c|c|}
\hline Analyte & Process/Cause & $\begin{array}{l}\text { Affect of } \\
\text { process on } \\
\text { Analyte } \\
\text { Aqueous } \\
\text { Concentration }\end{array}$ \\
\hline $\begin{array}{l}\text { Anions by } \\
\text { IC }\end{array}$ & $\begin{array}{l}\text { Interference during ion chromatography (IC) analysis } \\
\text { from monovalent organic anions, such as formate, acetate, } \\
\text { and glycolate }\end{array}$ & Increase \\
\hline $\begin{array}{l}\text { Alumin- } \\
\text { ate, free } \\
\text { hydroxide }\end{array}$ & Interference during titration with organic anions. & Increase \\
\hline Carbonate & Interference during titration with organic anions. & Decrease \\
\hline $\mathrm{Ag}$ & $\begin{array}{l}\text { Photoreduction of } \mathrm{Ag}^{+} \text {to } \mathrm{Ag}^{0} \text {, thereby decreasing solution } \\
\mathrm{Ag} \text { concentrations }\left(\mathrm{Ag}^{0} \text { would precipitate as a solid). }\right.\end{array}$ & Decrease \\
\hline Metals & $\begin{array}{l}\text { Insufficient amount of organic complexants (e.g., } \\
\text { HEDTA, IDA, EDTA, and gluconate) added to simulant } \\
\text { because of analytical error in the tank characterization. }\end{array}$ & Decrease \\
\hline $\begin{array}{l}\text { EDTA, } \\
\text { HEDTA } \\
\text { and IDA }\end{array}$ & $\begin{array}{l}\text { Ion Exclusion Chromatography (IEC) and derivatization- } \\
\text { GCMS rely on recovery calculations to adjust final } \\
\text { results. }\end{array}$ & $\begin{array}{l}\text { Decrease or } \\
\text { Increase }\end{array}$ \\
\hline $\begin{array}{l}\text { HEDTA } \\
\text { and EDTA }\end{array}$ & $\begin{array}{l}\text { Degradation during simulant production or during mixing } \\
\text { study. }\end{array}$ & Decrease \\
\hline IDA & Degradation of EDTA to form IDA & Increase \\
\hline Free $\mathrm{OH}$ & $\begin{array}{l}\text { Constant reopening of containers during daily turbidity } \\
\text { measurements permitted a unusually large amount of } \mathrm{CO}_{2} \\
\text { gas to be dissolved in water, thereby lowering free } \\
\text { hydroxide concentrations. }\end{array}$ & Decrease \\
\hline $\mathrm{Al}$ & $\begin{array}{l}\text { Decrease in } \mathrm{OH} \text { concentrations in solution due to removal } \\
\text { of atmospheric } \mathrm{CO}_{2} \text { would result in less } \mathrm{Al} \text { precipitation } \\
\text { as } \mathrm{Al}(\mathrm{OH})_{3} \text {. (See Free } \mathrm{OH} \text { Process/Cause above for how } \\
\mathrm{OH} \text { and atmospheric } \mathrm{CO}_{2} \text { interact). The resulting lower } \\
\text { solution pH would have increased solution } \mathrm{Al} \\
\text { concentrations. }\end{array}$ & Increase \\
\hline Al & $\begin{array}{l}\text { Al values in the Envelope A and B simulants were lower } \\
\text { than planned because the source of Al for the simulants } \\
\text { was a hydrated aluminum trihydroxide salt. Erroneously, } \\
\text { the mass of the water associated with the salt was not } \\
\text { accounted for in determining how much to include in the } \\
\text { simulants. The salt contained } 20 \mathrm{wt}-\% \text { water; } \\
\text { consequently, } 20 \mathrm{wt}-\% \text { less Al than needed was added to } \\
\text { the Envelope A and B simulants. }\end{array}$ & Decrease \\
\hline
\end{tabular}


The divalent metal cations that were present at less than the target concentration are generally characterized as forming insoluble carbonates and phosphates, but also stable complexes with chelating agents such as EDTA. Since the carbonate level was sufficiently high in the AN-107 simulant to generate sodium carbonate crystals (described above, see Figure B12 in Appendix B), it is not unexpected that the less soluble carbonates might also be removed during the simulant equilibration period and associated filtration. The presence of chelating agents in the AN-107 simulant should normally prevent the formation of the insoluble carbonates. However, the low level of measured EDTA might indicate that insufficient chelators were present. The AN-107 simulant also contains gluconate which also complexes metal ions. But the planned concentration of gluconate in the AN-107 simulant is not based on a measured value since a method for measuring gluconate in high ionic strength solutions similar to AN107 has not been developed. The level of gluconate was set based upon SRTC experience with the addition of ferric nitrate to the AN-107 simulant.

Another reason that the divalent cations were less than the target concentrations can also be seen in the measured versus planned oxalate concentration. The oxalate salts of these cations are relatively insoluble and would reduce the concentration of both the cations and the oxalate anion. Therefore, the reduced level of oxalate in the AN-107 simulant could be the result of not having sufficient complexing agents for all of the divalent cations.

The measured values for three of the complexing agents differed significantly from the planned target values: EDTA less than planned, and HEDTA and IDA greater than planned (Table 3). One possible reason for the difference could be an analytical problem since both of the methods used (ion exclusion chromatography and derivatizationGCMS) rely on recovery calculations to adjust the final result. An expected low recovery would generate a high result while an expected high recovery would produce the inverse. Another possibility for the EDTA and IDA results is that decomposition of the EDTA occurred during the simulant production. IDA is included in the AN-107 simulant because it is one of the major decomposition products of the original complexing agents and is a complexing agent itself. A higher level of IDA might, therefore, be caused by EDTA decomposition.

The results for Total Organic Carbon (TOC) are slightly higher than planned. However, actual TOC levels for AN-107 supernate are three times higher, $39 \mathrm{~g} / \mathrm{L}$ (Esch 1997). The planned AN-107 simulant composition did not attempt to match the measured TOC values since organic characterization has yet to identify all of the TOC in the AN-107 supernate and a portion of what has been identified is not commercially available. Scaling the measured organic compounds to the TOC result was also not attempted since this would greatly impact the charge balance. The result of attempting to match the measured TOC would require the addition of $\mathrm{Na}$ or some other cation beyond what has been measured. 
One of the special characteristics of the supernate in AN-107 is the extremely low level of free hydroxide, less than 0.02 molar. Consequently, the level of soluble aluminum in the supernate is also extremely low. Aluminum concentration in the salt solutions with $\mathrm{pH}$ greater than seven can be used as an indicator of the presence of free hydroxide anion. Since the targeted aluminum concentration was not achieved, the actual free hydroxide level must be less than planned. This could be due to the reaction of $\mathrm{CO}_{2}$ from the air with the free hydroxide to generate carbonate:

$$
\mathrm{CO}_{2}+2 \mathrm{NaOH} \longrightarrow \mathrm{Na}_{2} \mathrm{CO}_{3}+\mathrm{H}_{2} \mathrm{O}
$$

Contact with air during the feed stability period occurred regularly due to sampling for turbidity and more extensively during the two filtration processes. The result would be that some of the aluminate would convert back to $\mathrm{Al}(\mathrm{OH})_{3}$ and precipitate:

$$
\mathrm{Al}(\mathrm{OH})_{4}^{-} \longrightarrow \mathrm{Al}(\mathrm{OH})_{3}+\mathrm{OH}^{-}
$$

The form of zirconium used for the simulant recipe was zirconyl nitrate, $\mathrm{ZrO}\left(\mathrm{NO}_{3}\right)_{2} \cdot x \mathrm{H}_{2} \mathrm{O}$, which is an $x$-hydrate where $x$ is from 1 to 6 water molecules. Since the level of zirconium in all of the simulants was less than $100 \%$ of the planned concentration, the zirconyl nitrate was not adjusted for the presence of water of hydration. If $x$ was 1 , the $\mathrm{Zr}$ level would be $93 \%$ of the target. When $x$ is 6 , the zirconium is $68 \%$ of the target. The zirconyl nitrate used must have had 6 waters of hydration.

The impact of these variations from the planned composition on the objectives of this study is expected to be small. First, the concentrations achieved in the AN-107 simulant feed solution are within the range of concentrations observed for actual $\mathrm{C}$ envelope wastes. For example, the aluminum concentration in the simulant is lower than the analytical results from the actual AN-107 tank waste because of free hydroxide depletion. Hydroxide depletion is observed in the AN-107 supernate due to the impact of radiolysis in the presence of the organic complexing agents and due to $\mathrm{CO}_{2}$ absorption. Samples of AN-107 supernate collected over a range of time have shown aluminum concentrations trending lower as free hydroxide has trended lower. Second, these tests will be confirmed with shielded cell and radiobench tests with active samples from the actual tanks. This is necessary due to the inability to identify all possible compounds present in the actual waste and therefore to produce a perfect simulant.

The goal of experiments with waste simulants is to develop knowledge about waste chemistry and to provide some prediction of potential problems. However, since waste characterization is not perfect, the simulant may not exactly duplicate the actual waste. Therefore, results from simulated waste experiments must be confirmed by actual waste studies. 
Table 3. AN-107 Simulant Feed Composition.

\begin{tabular}{|c|c|c|c|c|c|}
\hline Component & Units & Found & Planned & $\%$ of Target & Methods \\
\hline $\mathrm{Ag}$ & $\mathrm{mg} / \mathrm{L}$ & $<0.3$ & 14 & $<2$ & ICP-ES \\
\hline $\mathrm{Al}$ & $\mathrm{mg} / \mathrm{L}$ & 194 & 386 & 50 & ICP-ES \\
\hline $\mathrm{B}$ & $\mathrm{mg} / \mathrm{L}$ & 38 & 35 & 108 & ICP-ES \\
\hline $\mathrm{Ba}$ & $\mathrm{mg} / \mathrm{L}$ & 0.17 & 7 & 2 & ICP-ES \\
\hline $\mathrm{Ca}$ & $\mathrm{mg} / \mathrm{L}$ & 138 & 591 & 23 & ICP-ES \\
\hline $\mathrm{Cd}$ & $\mathrm{mg} / \mathrm{L}$ & $<0.02$ & 64 & $<0.03$ & ICP-ES \\
\hline $\mathrm{Ce}$ & $\mathrm{mg} / \mathrm{L}$ & 50.2 & 53 & 95 & ICP-ES \\
\hline $\mathrm{Co}$ & $\mathrm{mg} / \mathrm{L}$ & 0.39 & $\mathrm{NM}^{\mathrm{a}}$ & -- & ICP-ES \\
\hline $\mathrm{Cr}$ & $\mathrm{mg} / \mathrm{L}$ & 148 & 176 & 84 & ICP-ES \\
\hline Cs & $\mathrm{mg} / \mathrm{L}$ & 22.3 & 18.6 & 120 & $\mathrm{AA}$ \\
\hline $\mathrm{Cu}$ & $\mathrm{mg} / \mathrm{L}$ & 32 & 30 & 106 & ICP-ES \\
\hline $\mathrm{Fe}$ & $\mathrm{mg} / \mathrm{L}$ & 1623 & 1690 & 96 & ICP-ES \\
\hline $\mathrm{K}$ & $\mathrm{mg} / \mathrm{L}$ & 1921 & 1810 & 106 & AA \\
\hline $\mathrm{La}$ & $\mathrm{mg} / \mathrm{L}$ & 40 & 46 & 88 & ICP-ES \\
\hline $\mathrm{Mg}$ & $\mathrm{mg} / \mathrm{L}$ & 20 & 25 & 79 & ICP-ES \\
\hline $\mathrm{Mn}$ & $\mathrm{mg} / \mathrm{L}$ & 564 & 563 & 100 & ICP-ES \\
\hline Mo & $\mathrm{mg} / \mathrm{L}$ & 36 & 36 & 100 & ICP-ES \\
\hline $\mathrm{Na}$ & $\mathrm{mg} / \mathrm{L}$ & 188170 & 195000 & 96 & ICP-ES \\
\hline $\mathrm{Na}$ & $\mathrm{mg} / \mathrm{L}$ & 201400 & 195000 & 103 & $\mathrm{AA}$ \\
\hline $\mathrm{Nd}$ & $\mathrm{mg} / \mathrm{L}$ & 84.4 & 96 & 88 & ICP-ES \\
\hline $\mathrm{Ni}$ & $\mathrm{mg} / \mathrm{L}$ & 501 & 530 & 95 & ICP-ES \\
\hline $\mathrm{P}$ & $\mathrm{mg} / \mathrm{L}$ & 420 & 362 & 116 & ICP-ES \\
\hline $\mathrm{Pb}$ & $\mathrm{mg} / \mathrm{L}$ & 364 & 388 & 94 & ICP-ES \\
\hline $\mathrm{Si}$ & $\mathrm{mg} / \mathrm{L}$ & 1.4 & $\mathrm{NM}$ & -- & ICP-ES \\
\hline $\mathrm{Sn}$ & $\mathrm{mg} / \mathrm{L}$ & $<0.26$ & $\mathrm{NM}$ & -- & ICP-ES \\
\hline $\mathrm{Sr}$ & $\mathrm{mg} / \mathrm{L}$ & 1.3 & 6.6 & 20 & ICP-ES \\
\hline $\mathrm{Ti}$ & $\mathrm{mg} / \mathrm{L}$ & $<0.14$ & $\mathrm{NM}$ & -- & ICP-ES \\
\hline $\mathrm{Zn}$ & $\mathrm{mg} / \mathrm{L}$ & 44 & 45 & 98 & ICP-ES \\
\hline $\mathrm{Zr}$ & $\mathrm{mg} / \mathrm{L}$ & 45 & 70 & 64 & ICP-ES \\
\hline Chloride & $\mathrm{mg} / \mathrm{L}$ & 1330 & 1100 & 121 & $\mathrm{IC}$ \\
\hline Fluoride & $\mathrm{mg} / \mathrm{L}$ & 3430 & 133 & 2579 & $\mathrm{IC}$ \\
\hline Formate & $\mathrm{mg} / \mathrm{L}$ & 11232 & 10400 & 108 & $\mathrm{IC}$ \\
\hline Nitrate & $\mathrm{mg} / \mathrm{L}$ & 213930 & 230000 & 93 & $\mathrm{IC}$ \\
\hline Nitrite & $\mathrm{mg} / \mathrm{L}$ & 57090 & 61000 & 94 & IC \\
\hline Oxalate & $\mathrm{mg} / \mathrm{L}$ & 335 & 826 & 41 & $\mathrm{IC}$ \\
\hline Phosphate & $\mathrm{mg} / \mathrm{L}$ & 1500 & 1110 & 135 & $\mathrm{IC}$ \\
\hline Sulfate & $\mathrm{mg} / \mathrm{L}$ & 7280 & 8250 & 88 & $\mathrm{IC}$ \\
\hline TIC & $\mathrm{mg} / \mathrm{L}$ & 16100 & 16800 & 96 & $\mathrm{CO}_{2}$ Evolution \\
\hline TOC & $\mathrm{mg} / \mathrm{L}$ & 15800 & 12450 & 127 & $\mathrm{CO}_{2}$ Evolution \\
\hline Carbonate (TIC) & $\mathrm{mg} / \mathrm{L}$ & 80439 & 83940 & 96 & Calc. from TIC \\
\hline Aluminate & Molar & 0.054 & 0.014 & 378 & Titration \\
\hline Carbonate & Molar & 1.052 & 1.400 & 75 & Titration \\
\hline Free $\mathrm{OH}$ & Molar & 0.039 & 0.020 & 197 & Titration \\
\hline
\end{tabular}


Table 4. AN-107 Simulant Feed Organic Composition.

\begin{tabular}{|c|c|c|c|c|c|}
\hline Component & Units & Found & Planned & \% of Target & Methods \\
\hline EDTA & $\mathrm{mg} / \mathrm{L}$ & 1088 & 5620 & 19 & IPC \\
\hline HEDTA & $\mathrm{mg} / \mathrm{L}$ & 3231 & 2140 & 151 & IPC \\
\hline Glycolate & $\mathrm{mg} / \mathrm{L}$ & 18864 & 18600 & 101 & IEC \\
\hline Citrate & $\mathrm{mg} / \mathrm{L}$ & 8952 & 8495 & 105 & IEC \\
\hline Formate & $\mathrm{mg} / \mathrm{L}$ & 12374 & 10400 & 119 & IEC \\
\hline Acetate & $\mathrm{mg} / \mathrm{L}$ & 964 & 1100 & 88 & IEC \\
\hline Iminodiacetic Acid & $\mathrm{mg} / \mathrm{L}$ & 8251 & 5947 & 139 & GCMS \\
\hline
\end{tabular}

\subsection{2. $\quad$ AW-101 Simulant}

The AW-101 simulant recipe was based on chemical characterization data of the supernate from Hanford tank 241-AW-101, as diluted to a sodium concentration of 6.46 molar (Urie et al. 1999). The simulant is a high hydroxide, high aluminate, Envelope A tank. As shown in Figure 1, the turbidity of the AW-101 simulant began to increase rapidly 8 -days after it was made. The feed was filtered through a 0.45 - $\mu \mathrm{m}$ nylon filter and monitoring resumed. No further increase in turbidity was observed. The planned and as produced composition is presented in Table 5. The solids concentration, determined by microwave drying was $36.0 \%$ (wt.). The density of the feed solution was $1.304 \mathrm{~g} / \mathrm{mL}$.

There was $>20 \%$ deviation in concentrations between the "Found" and "Planned" concentration of the following analytes: $\mathrm{Al}, \mathrm{P}, \mathrm{Pb}, \mathrm{Cl}, \mathrm{F}, \mathrm{PO}_{4}{ }^{3-}, \mathrm{SO}_{4}{ }^{2-}, \mathrm{TIC}, \mathrm{Al}(\mathrm{OH})_{4}$, $\mathrm{CO}_{3}{ }^{2-}$, and free hydroxide. The differences can be categorized as the results of: (1) starting reagent, (2) lack of complexing reagents, (3) absorption of carbon dioxide during filtering and turbidity monitoring and (4) solubility problems. A brief summary for some of the causes that may be responsible for the discrepancies between the planned and found concentrations is presented in Table 2 .

The aluminum value as reported by ICP-ES and by titration was lower than planned because the aluminum trihydroxide used in the study contained $20 \mathrm{wt}-\%$ water. The same trihydroxide source was used in the other A and B Tank simulants (AN-104, AZ101, and AZ-102). The resulting aluminum levels are still within the range expected for actual $\mathrm{A}$ and $\mathrm{B}$ envelope tanks.

The basis for the simulant feed did not report any organic species such as oxalate as present in the diluted supernate despite the diluted AW-101 supernate having a measured TOC of 1.56 grams/Liter (Urie et al. 1999). Therefore, no potential complexing agents 
WSRC-TR-2000-00319

SRT-RPP-2000-00020

Revision 0

were included in the simulant feed. Thus, lower than planned concentrations of metals such as lead might be due to the lack of such complexing agents.

The extensive handling of the simulated feed during feed makeup, filtration (filtered three times) and sampling for turbidity monitoring can lead to absorption of carbon dioxide. The $\mathrm{CO}_{2}$ would react with the free hydroxide to generate carbonate by reaction (1). The net result would be a reduction in free hydroxide and an increase in carbonate. As the free hydroxide declines the amount of aluminate would also be reduced since the aluminate depends directly on the free hydroxide. Calculating a total hydroxide concentration by summing the free hydroxide and twice the carbonate mole concentration results in 3.041 molar free hydroxide in the AW-101 simulant and 3.408 molar free hydroxide in the planned simulant, or about $90 \%$ of the planned amount. Therefore, it appears that the in-growth of carbonate has occurred during the feed stabilization period. The same process can occur within the waste tanks due to the vapor space purge to minimize hydrogen flammability concerns.

Solubility problems have been reported previously for Hanford waste supernates such as AW-101 due to presence of double salts of fluoride and phosphate (Calloway et al. 2000). The low results for fluoride, phosphorus and phosphate could be due to the formation of sodium fluorophosphate, which has a low solubility. The long equilibration period prior to the final filtration and submission of the supernate for analysis would allow formation of the double salt, which is known to have slow kinetics of formation. The three filtration steps that the simulant was processed through would remove the double salt.

The net impact of these differences on the goal of this study is expected to be small since all of the analytical results are within the range of expected conditions for Envelope A waste tanks. The growth of carbonate within alkaline waste supernate is an expected process as is the precipitation of salts due to the supernate reaching the solubility limits for such things as double salts. The goal of experiments with waste simulants is to develop knowledge about waste chemistry and to provide some prediction of potential problems. However, since waste characterization is not perfect, the simulant may not exactly duplicate the actual waste. Therefore, results from simulated waste experiments must be confirmed by actual waste studies. 
WSRC-TR-2000-00319

SRT-RPP-2000-00020

Revision 0

Table 5. AW-101 Simulant Feed Composition.

\begin{tabular}{|c|c|c|c|c|c|}
\hline Component & Units & Found & Planned & $\%$ of Target & Methods \\
\hline $\mathrm{Ag}$ & $\mathrm{mg} / \mathrm{L}$ & $<0.3$ & $\mathrm{NM}^{\mathrm{a}}$ & -- & ICP-ES \\
\hline $\mathrm{Al}$ & $\mathrm{mg} / \mathrm{L}$ & 12150 & 16350 & 74 & ICP-ES \\
\hline B & $\mathrm{mg} / \mathrm{L}$ & $<0.21$ & NM & -- & $\begin{array}{l}\text { ICP-ES } \\
\end{array}$ \\
\hline $\mathrm{Ba}$ & $\mathrm{mg} / \mathrm{L}$ & 0.12 & NM & -- & ICP-ES \\
\hline $\mathrm{Ca}$ & $\mathrm{mg} / \mathrm{L}$ & 2.2 & $\mathrm{NM}$ & -- & ICP-ES \\
\hline $\mathrm{Cd}$ & $\mathrm{mg} / \mathrm{L}$ & $<0.02$ & NM & -- & ICP-ES \\
\hline $\mathrm{Ce}$ & $\mathrm{mg} / \mathrm{L}$ & $<0.7$ & NM & -- & ICP-ES \\
\hline Co & $\mathrm{mg} / \mathrm{L}$ & $<0.05$ & $\mathrm{NM}$ & -- & ICP-ES \\
\hline $\mathrm{Cr}$ & $\mathrm{mg} / \mathrm{L}$ & 45 & 56 & 81 & ICP-ES \\
\hline Cs & $\mathrm{mg} / \mathrm{L}$ & 11.8 & 11 & 107 & AA \\
\hline $\mathrm{Cu}$ & $\mathrm{mg} / \mathrm{L}$ & 0.18 & NM & -- & ICP-ES \\
\hline $\mathrm{Fe}$ & $\mathrm{mg} / \mathrm{L}$ & 0.29 & NM & -- & ICP-ES \\
\hline $\mathrm{K}$ & $\mathrm{mg} / \mathrm{L}$ & 22730 & 23000 & 99 & AA \\
\hline $\mathrm{La}$ & $\mathrm{mg} / \mathrm{L}$ & $<0.06$ & NM & -- & ICP-ES \\
\hline $\mathrm{Mg}$ & $\mathrm{mg} / \mathrm{L}$ & $<0.09$ & $\mathrm{NM}$ & -- & ICP-ES \\
\hline $\mathrm{Mn}$ & $\mathrm{mg} / \mathrm{L}$ & 0.04 & $\mathrm{NM}$ & -- & ICP-ES \\
\hline Mo & $\mathrm{mg} / \mathrm{L}$ & 0.17 & NM & -- & ICP-ES \\
\hline $\mathrm{Na}$ & $\mathrm{mg} / \mathrm{L}$ & 138670 & 148500 & 93 & ICP-ES \\
\hline $\mathrm{Na}$ & $\mathrm{mg} / \mathrm{L}$ & 137530 & 148500 & 93 & AA \\
\hline $\mathrm{Nd}$ & $\mathrm{mg} / \mathrm{L}$ & $<0.3$ & NM & -- & ICP-ES \\
\hline $\mathrm{Ni}$ & $\mathrm{mg} / \mathrm{L}$ & 0.32 & NM & -- & ICP-ES \\
\hline $\mathrm{P}$ & $\mathrm{mg} / \mathrm{L}$ & 343 & 635 & 54 & ICP-ES \\
\hline $\mathrm{Pb}$ & $\mathrm{mg} / \mathrm{L}$ & 28 & 41 & 68 & ICP-ES \\
\hline $\mathrm{Si}$ & $\mathrm{mg} / \mathrm{L}$ & 125 & 130 & 96 & ICP-ES \\
\hline $\mathrm{Sr}$ & $\mathrm{mg} / \mathrm{L}$ & 0.11 & $\mathrm{NM}$ & -- & ICP-ES \\
\hline $\mathrm{Ti}$ & $\mathrm{mg} / \mathrm{L}$ & $<0.14$ & $\mathrm{NM}$ & -- & ICP-ES \\
\hline $\mathrm{Zn}$ & $\mathrm{mg} / \mathrm{L}$ & 15 & 14 & 109 & ICP-ES \\
\hline $\mathrm{Zr}$ & $\mathrm{mg} / \mathrm{L}$ & 0.06 & $\mathrm{NM}$ & -- & ICP-ES \\
\hline Chloride & $\mathrm{mg} / \mathrm{L}$ & 2570 & 3300 & 78 & IC \\
\hline Fluoride & $\mathrm{mg} / \mathrm{L}$ & 112.0 & 830.0 & 13 & IC \\
\hline Formate & $\mathrm{mg} / \mathrm{L}$ & $<100$ & NM & -- & IC \\
\hline Nitrate & $\mathrm{mg} / \mathrm{L}$ & 105344 & 123000 & 86 & IC \\
\hline Nitrite & $\mathrm{mg} / \mathrm{L}$ & 59905 & 62750 & 95 & IC \\
\hline Oxalate & $\mathrm{mg} / \mathrm{L}$ & $<100$ & $\mathrm{NM}$ & -- & IC \\
\hline Phosphate & $\mathrm{mg} / \mathrm{L}$ & 799 & 1950 & 41 & IC \\
\hline Sulfate & $\mathrm{mg} / \mathrm{L}$ & 2403 & 1850 & 130 & IC \\
\hline TIC & $\mathrm{mg} / \mathrm{L}$ & 9620 & 2155 & 446 & $\mathrm{CO}_{2}$ Evolution \\
\hline TOC & $\mathrm{mg} / \mathrm{L}$ & $<200$ & $\mathrm{NM}$ & -- & $\mathrm{CO}_{2}$ Evolution \\
\hline Carbonate (TIC) & $\mathrm{mg} / \mathrm{L}$ & 48063 & 10767 & 446 & Calc. from TIC \\
\hline Aluminate & Molar & 0.365 & 0.606 & 60 & Titration \\
\hline Free $\mathrm{OH}$ & Molar & 2.133 & 3.050 & 70 & Titration \\
\hline Carbonate & Molar & 0.454 & 0.179 & 254 & Titration \\
\hline
\end{tabular}




\subsection{3. $\quad$ AN-104 Simulant}

The AN-104 simulant recipe is based upon a retrieval scenario in which the entire tank is mixed and then water is added to achieve $50 \%$ dilution by volume (Herting 1998). The resulting supernate contains 7.61 molar sodium and substantially higher concentrations of phosphate, sulfate and carbonate due to dissolution of salts within the solids present in $\mathrm{AN}-104$. A comparison with a supernate based upon the same treatment for AN-105 suggested that the AN-104 simulant is a conservative bounding case and adequately represents AN-105 for the purposes of this study (Herting 1995). The oxalate concentration used in the AN-104 simulant was taken from the $\mathrm{AN}-105$ reference due to the $\mathrm{AN}-104$ measurement being reported as a less than value while oxalate was expected to be present. Due to the addition of water in the presence of the crystallized salts in AN104, the supernate is likely saturated with carbonates, phosphates and sulfates salts. Similar to the AW-101 simulant, the AN-104 simulant required filtering part way through the equilibrium period and is so noted on Figure 1. Table 6 provides the planned and as "found" composition of the AN-104 simulant. The final feed simulant had a density of $1.342 \mathrm{~g} / \mathrm{mL}$. Based upon microwave drying to a constant weight, the total solids in the simulant was 39 wt- $\%$.

There was $>20 \%$ deviation in concentrations between the "found" and "planned" concentration of the following analytes: $\mathrm{Ag}, \mathrm{Al}, \mathrm{P}, \mathrm{F}, \mathrm{Oxalate}, \mathrm{PO}_{4}{ }^{3-}, \mathrm{TIC}, \mathrm{Al}(\mathrm{OH})_{4}{ }^{-}$, $\mathrm{CO}_{3}{ }^{2-}$, and free hydroxide. The differences can be categorized as being due to: (1) lack of stability for the specific element, (2) the starting reagent, (3) absorption of carbon dioxide during filtering and turbidity monitoring and (4) solubility problems. A brief summary for some of the causes that may be responsible for the discrepancies between the planned and found concentrations is presented in Table 2.

Silver was supposed to have a concentration of $13 \mathrm{mg} / \mathrm{L}$ in the AN-104 feed simulant. The soluble silver, after the feed stability period was complete, was less than detection limits. Since none of the feeds was protected from light, photoreduction of the aqueous silver cation was the probable mechanism by which the silver target concentration was missed. Given the expected low concentration of silver in the Envelope A waste envelope and the ease of reduction, the absence of silver from the tested solutions should not have any impact on the goal of the experiments.

The aluminum value as reported by ICP-ES and by titration was lower than planned because the aluminum trihydroxide used in this study contained $\sim 20 \mathrm{wt}-\%$ water. The same trihydroxide source was used in the other A and B Tank simulants (AW-101, AZ101, and AZ-102). The resulting aluminum levels are still within the range expected for actual Envelope A and B tanks.

The extensive handling of the simulated feed during feed makeup, filtration (filtered three times) and sampling for turbidity monitoring can lead to absorption of carbon dioxide. The $\mathrm{CO}_{2}$ would react with the free hydroxide to generate carbonate by reaction (1). The net result would be a reduction in free hydroxide and an increase in carbonate. As the 
WSRC-TR-2000-00319

SRT-RPP-2000-00020

Revision 0

free hydroxide declined the amount of aluminate would also be reduced since the aluminate depends directly on the free hydroxide. Calculating a total hydroxide concentration by summing the free hydroxide and twice the carbonate mole concentration results in 3.432 molar free hydroxide in the AW-101 simulant and 3.728 molar free hydroxide in the planned simulant, or about $92 \%$ of the planned concentration. Therefore, it appears that the ingrowth of carbonate has occurred during the feed stability period. The same process can occur within the waste tanks due to the vapor space purge to minimize hydrogen flammability concerns.

Solubility problems have been reported previously for Hanford waste supernates such as AN-104, due to presence of double salts of fluoride and phosphate (Calloway et al. 2000). The low results for fluoride, phosphorus and phosphate could be due to the formation of sodium fluorophosphate, which has a low solubility. The long equilibration period prior to the final filtration and submission of the supernate for analysis would allow formation of the double salt, which is known to have slow kinetics of formation. The three-filtration steps that the simulant was processed through would remove the double salt.

As mentioned above, the oxalate concentration planned for the AN-104 simulant is not actually based on the AN-104 sample analysis. Since it was desirable to have oxalate present in at least one of the Envelope A simulants, the concentration used came from the supernate of $\mathrm{AN}-105$. Whether the concentration measured in $\mathrm{AN}-105$ supernate is appropriate for composition of AN-104 was not considered. The measured level in the AN-104 simulant could be the correct level for that overall composition.

The net impact of these differences on the goal of this study is expected to be small since all of the analytical results are within the range of expected conditions for Envelope A waste tanks. The growth of carbonate within alkaline waste supernate is an expected process as is the precipitation of salts due to the supernate reaching the solubility limits for such things as double salts. The goal of experiments with waste simulants is to develop knowledge about waste chemistry and to provide some prediction of potential problems. However, since waste characterization is not perfect, the simulant may not exactly duplicate the actual waste. Therefore, results from simulated waste experiments must be confirmed by actual waste studies. 
WSRC-TR-2000-00319

SRT-RPP-2000-00020

Revision 0

Table 6. AN-104 Simulant Feed Composition.

\begin{tabular}{|c|c|c|c|c|c|}
\hline Component & Units & Found & Target & \% of Target & Methods \\
\hline $\mathrm{Ag}$ & $\mathrm{mg} / \mathrm{L}$ & $<0.3$ & 13 & $<2$ & ICP-ES \\
\hline $\mathrm{Al}$ & $\mathrm{mg} / \mathrm{L}$ & 16952 & 23200 & 73 & ICP-ES \\
\hline $\mathrm{B}$ & $\mathrm{mg} / \mathrm{L}$ & 33 & 33 & 101 & ICP-ES \\
\hline $\mathrm{Ba}$ & $\mathrm{mg} / \mathrm{L}$ & 5.6 & $\mathrm{NM}^{\mathrm{a}}$ & -- & ICP-ES \\
\hline $\mathrm{Ca}$ & $\mathrm{mg} / \mathrm{L}$ & 2.8 & $\mathrm{NM}$ & -- & ICP-ES \\
\hline $\mathrm{Cd}$ & $\mathrm{mg} / \mathrm{L}$ & $<0.02$ & NM & -- & ICP-ES \\
\hline $\mathrm{Ce}$ & $\mathrm{mg} / \mathrm{L}$ & $<0.7$ & NM & -- & ICP-ES \\
\hline $\mathrm{Co}$ & $\mathrm{mg} / \mathrm{L}$ & $<0.05$ & $\mathrm{NM}$ & -- & ICP-ES \\
\hline $\mathrm{Cr}$ & $\mathrm{mg} / \mathrm{L}$ & 204 & 248 & 82 & ICP-ES \\
\hline Cs & $\mathrm{mg} / \mathrm{L}$ & 0.7 & NM & -- & AA \\
\hline $\mathrm{Cu}$ & $\mathrm{mg} / \mathrm{L}$ & 0.14 & $\mathrm{NM}$ & -- & ICP-ES \\
\hline $\mathrm{Fe}$ & $\mathrm{mg} / \mathrm{L}$ & 0.31 & NM & -- & ICP-ES \\
\hline $\mathrm{K}$ & $\mathrm{mg} / \mathrm{L}$ & 4320 & 4050 & 107 & $\overline{\mathrm{AA}}$ \\
\hline $\mathrm{La}$ & $\mathrm{mg} / \mathrm{L}$ & $<0.06$ & NM & -- & ICP-ES \\
\hline $\mathrm{Mg}$ & $\mathrm{mg} / \mathrm{L}$ & $<0.09$ & NM & -- & ICP-ES \\
\hline $\mathrm{Mn}$ & $\mathrm{mg} / \mathrm{L}$ & $<0.009$ & $\mathrm{NM}$ & -- & ICP-ES \\
\hline Mo & $\mathrm{mg} / \mathrm{L}$ & 49 & 50 & 98 & ICP-ES \\
\hline $\mathrm{Na}$ & $\mathrm{mg} / \mathrm{L}$ & 164670 & 175000 & 94 & ICP-ES \\
\hline $\mathrm{Na}$ & $\mathrm{mg} / \mathrm{L}$ & 168200 & 175000 & 96 & AA \\
\hline $\mathrm{Nd}$ & $\mathrm{mg} / \mathrm{L}$ & $<0.3$ & NM & -- & ICP-ES \\
\hline $\mathrm{Ni}$ & $\mathrm{mg} / \mathrm{L}$ & 0.41 & NM & -- & ICP-ES \\
\hline $\mathrm{P}$ & $\mathrm{mg} / \mathrm{L}$ & 444 & 957 & 46 & ICP-ES \\
\hline $\mathrm{Pb}$ & $\mathrm{mg} / \mathrm{L}$ & $<0.6$ & $\mathrm{NM}$ & -- & ICP-ES \\
\hline $\mathrm{Si}$ & $\mathrm{mg} / \mathrm{L}$ & 169 & 153 & 111 & ICP-ES \\
\hline $\mathrm{Sr}$ & $\mathrm{mg} / \mathrm{L}$ & 0.09 & $\mathrm{NM}$ & -- & ICP-ES \\
\hline $\mathrm{Ti}$ & $\mathrm{mg} / \mathrm{L}$ & 0.15 & $\mathrm{NM}$ & -- & ICP-ES \\
\hline $\mathrm{Zn}$ & $\mathrm{mg} / \mathrm{L}$ & 3.4 & $\mathrm{NM}$ & -- & ICP-ES \\
\hline $\mathrm{Zr}$ & $\mathrm{mg} / \mathrm{L}$ & $<0.05$ & $\mathrm{NM}$ & -- & ICP-ES \\
\hline Chloride & $\mathrm{mg} / \mathrm{L}$ & 5861 & 5100 & 115 & IC \\
\hline Fluoride & $\mathrm{mg} / \mathrm{L}$ & $<200$ & 506.0 & $<40$ & IC \\
\hline Formate & $\mathrm{mg} / \mathrm{L}$ & $<100$ & NM & - & $\mathrm{IC}$ \\
\hline Nitrate & $\mathrm{mg} / \mathrm{L}$ & 85960 & 102000 & 84 & IC \\
\hline Nitrite & $\mathrm{mg} / \mathrm{L}$ & 62530 & 64500 & 97 & IC \\
\hline Oxalate & $\mathrm{mg} / \mathrm{L}$ & 160 & 549 & 29 & $\mathrm{IC}$ \\
\hline Phosphate & $\mathrm{mg} / \mathrm{L}$ & 868 & 2930 & 30 & IC \\
\hline Sulfate & $\mathrm{mg} / \mathrm{L}$ & 5744 & 7120 & 81 & IC \\
\hline TIC & $\mathrm{mg} / \mathrm{L}$ & 12314 & 7490 & 164 & $\mathrm{CO}_{2}$ Evolution \\
\hline TOC & $\mathrm{mg} / \mathrm{L}$ & 3628 & NM & -- & $\mathrm{CO}_{2}$ Evolution \\
\hline Carbonate (TIC) & $\mathrm{mg} / \mathrm{L}$ & 61523 & 37421 & 164 & Calc. from TIC \\
\hline Aluminate & Molar & 0.636 & 0.860 & 74 & Titration \\
\hline Carbonate & Molar & 0.763 & 0.624 & 122 & Titration \\
\hline Free $\mathrm{OH}$ & Molar & 1.906 & 2.480 & 77 & Titration \\
\hline
\end{tabular}




\subsubsection{AZ-101 Simulant}

The AZ-101 simulant recipe is based on the Best Basis Inventory composition for the AZ-101 supernate as of October 1, 1998. Tank AZ-101 is an Envelope B tank and is a simple simulant with very few minor components in contrast with the more detailed Envelope A and C simulants. No rise in turbidity, suggesting the formation of precipitates, was observed during the feed preparation or equilibration period. The planned and actual composition for the AZ-101 simulant is presented in Table 7. The density of the simulant was $1.227 \mathrm{~g} / \mathrm{mL}$ and the solids concentration determined by microwave drying was $29.84 \mathrm{wt}-\%$.

There was $>20 \%$ deviation in concentrations between the "found" and "planned" concentration of the following analytes: $\mathrm{Al}, \mathrm{Zr}, \mathrm{F}, \mathrm{TIC}, \mathrm{Al}(\mathrm{OH})_{4}$. The differences can be categorized as being due to: (1) the starting reagent, (2) lack of complexing reagents, and (3) analytical problems. A brief summary for some of the causes that may be responsible for the discrepancies between the planned and found concentrations is presented in Table 2.

The aluminum value as reported by ICP-ES and by titration was lower than planned because the aluminum trihydroxide used in the study contained $20 \%$ wt- $\%$ water. The same trihydroxide source was used in the other A and B Tank simulants (AN-104, AW101, and AZ-102). The resulting aluminum levels are still within the range expected for actual $\mathrm{A}$ and $\mathrm{B}$ envelope tanks. The $\mathrm{Al}(\mathrm{OH})_{4}$ result agrees well with the ICP-ES result for aluminum.

The Best Basis inventory did not provide a basis for adding any organic carbon to the simulant. Therefore, the potential exists for not including the necessary complexing agents to assist in keeping any trace metal such as zirconium soluble. The AZ-101 Tank Characterization report indicates a TOC value of $1030 \mathrm{mg} / \mathrm{L}$ based upon a 1995 grab sample (Hodgson 1995). Therefore, a better simulant should include some oxalate and other organic anions.

A comparison of the TIC result with the carbonate titration result suggests that there was a problem with the TIC measurement on this feed. The carbonate titration result agreed well with the planned carbonate concentration. It is not known why the "found" fluorine concentration was only $42 \%$ of the "planned" concentration.

The net impact of these differences on the goal of this study is expected to be small since all of the analytical results are within the range of expected conditions for Envelope B waste tanks. The growth of carbonate within alkaline waste supernate is an expected process as is the precipitation of salts due to the supernate reaching the solubility limits for such things as double salts. The goal of experiments with waste simulants is to develop knowledge about waste chemistry and to provide some prediction of potential problems. However, since waste characterization is not perfect, the simulant may not 
WSRC-TR-2000-00319

SRT-RPP-2000-00020

Revision 0

exactly duplicate the actual waste. Therefore, results from simulated waste experiments must be confirmed by actual waste studies.

Table 7. AZ-101 Simulant Feed Composition.

\begin{tabular}{|c|c|c|c|c|c|}
\hline Component & Units & Found & Planned & $\%$ of Target & Methods \\
\hline $\mathrm{Al}$ & $\mathrm{mg} / \mathrm{L}$ & 7752 & 10668 & 73 & ICP-ES \\
\hline $\mathrm{B}$ & $\mathrm{mg} / \mathrm{L}$ & $<0.21$ & $\mathrm{NM}^{\mathrm{a}}$ & -- & ICP-ES \\
\hline $\mathrm{Ba}$ & $\mathrm{mg} / \mathrm{L}$ & 0.02 & NM & -- & ICP-ES \\
\hline $\mathrm{Ca}$ & $\mathrm{mg} / \mathrm{L}$ & 3.7 & NM & -- & ICP-ES \\
\hline $\mathrm{Ce}$ & $\mathrm{mg} / \mathrm{L}$ & $<0.7$ & NM & -- & ICP-ES \\
\hline $\mathrm{Cr}$ & $\mathrm{mg} / \mathrm{L}$ & 648 & 730 & 89 & ICP-ES \\
\hline Cs & $\mathrm{mg} / \mathrm{L}$ & 41 & 37 & 111 & $\mathrm{AA}$ \\
\hline $\mathrm{Fe}$ & $\mathrm{mg} / \mathrm{L}$ & 0.46 & NM & -- & ICP-ES \\
\hline $\mathrm{K}$ & $\mathrm{mg} / \mathrm{L}$ & 4690 & 4624 & 101 & $\mathrm{AA}$ \\
\hline $\mathrm{La}$ & $\mathrm{mg} / \mathrm{L}$ & $<0.06$ & NM & -- & ICP-ES \\
\hline $\mathrm{Mg}$ & $\mathrm{mg} / \mathrm{L}$ & $<0.09$ & NM & -- & ICP-ES \\
\hline $\mathrm{Mn}$ & $\mathrm{mg} / \mathrm{L}$ & 0.11 & NM & -- & ICP-ES \\
\hline Mo & $\mathrm{mg} / \mathrm{L}$ & $<0.1$ & NM & -- & ICP-ES \\
\hline $\mathrm{Na}$ & $\mathrm{mg} / \mathrm{L}$ & 104670 & 108989 & 96 & ICP-ES \\
\hline $\mathrm{Na}$ & $\mathrm{mg} / \mathrm{L}$ & 108990 & 108990 & 100 & AA \\
\hline $\mathrm{Ni}$ & $\mathrm{mg} / \mathrm{L}$ & 0.34 & NM & -- & ICP-ES \\
\hline $\mathrm{P}$ & $\mathrm{mg} / \mathrm{L}$ & 546 & 489 & 112 & ICP-ES \\
\hline $\mathrm{Si}$ & $\mathrm{mg} / \mathrm{L}$ & 5.3 & NM & -- & ICP-ES \\
\hline $\mathrm{Zr}$ & $\mathrm{mg} / \mathrm{L}$ & 0.32 & 3.1 & 10 & ICP-ES \\
\hline Chloride & $\mathrm{mg} / \mathrm{L}$ & 180 & 200 & 90 & IC \\
\hline Fluoride & $\mathrm{mg} / \mathrm{L}$ & 760.0 & 1813.0 & 42 & $\mathrm{IC}$ \\
\hline Formate & $\mathrm{mg} / \mathrm{L}$ & $<100$ & NM & -- & IC \\
\hline Nitrate & $\mathrm{mg} / \mathrm{L}$ & 60330 & 75630 & 80 & $\mathrm{IC}$ \\
\hline Nitrite & $\mathrm{mg} / \mathrm{L}$ & 61770 & 65060 & 95 & $\mathrm{IC}$ \\
\hline Oxalate & $\mathrm{mg} / \mathrm{L}$ & $<100$ & NM & -- & IC \\
\hline Phosphate & $\mathrm{mg} / \mathrm{L}$ & 1318 & 1503 & 88 & IC \\
\hline Sulfate & $\mathrm{mg} / \mathrm{L}$ & 15740 & 17670 & 89 & IC \\
\hline TIC & $\mathrm{mg} / \mathrm{L}$ & 8466 & 4620 & 183 & \\
\hline TOC & $\mathrm{mg} / \mathrm{L}$ & 365 & NM & -- & \\
\hline Carbonate (TIC) & $\mathrm{mg} / \mathrm{L}$ & 42298 & 23082 & 183 & Calc. from TIC \\
\hline Aluminate & Molar & 0.268 & 0.395 & 68 & Titration \\
\hline Carbonate & Molar & 0.384 & 0.385 & 100 & Titration \\
\hline Free $\mathrm{OH}$ & Molar & 0.463 & 0.531 & 87 & Titration \\
\hline \multicolumn{6}{|c|}{$\mathrm{a} M=$ Not measured. } \\
\hline
\end{tabular}




\subsubsection{AZ-102 Simulant}

The AZ-102 simulant recipe is based upon the recently received Envelope B sample obtained from Hanford tank 241-AZ-102 (Hay 2000) and a core sample (Gray et al. 1993). To insure that the simulant included all of the trace metals, the recipe used the trace metal values from the core sample for the planned composition. The resulting simulant represents a more complete Envelope B simulant than the AZ-101 simulant. Table 8 contains the planned and actual composition of the simulant. No special problems with regards to precipitate formation were encountered during the preparation of this simulant. The density of the simulant was $1.118 \mathrm{~g} / \mathrm{mL}$ and the total solids in the simulant was $15.76 \mathrm{wt}-\%$.

There was $>20 \%$ deviation in concentrations between the "found" and "planned" concentration of the following analytes: $\mathrm{Ag}, \mathrm{Al}, \mathrm{Ba}, \mathrm{Ca}, \mathrm{Cd}, \mathrm{Cu}, \mathrm{Fe}, \mathrm{La}, \mathrm{Mg}, \mathrm{Mn}, \mathrm{Nd}, \mathrm{Ni}$, $\mathrm{Pb}, \mathrm{Si}, \mathrm{Sr}, \mathrm{Zr}$, TIC, and free hydroxide. The differences can be categorized as being due to: (1) the starting reagent, (2) lack of solubility, (3) lack of complexing agents and (4) analytical problems. A brief summary for some of the causes that may be responsible for the discrepancies between the planned and found concentrations is presented in Table 2 .

The aluminum value as reported by ICP-ES and by titration was lower than planned because the aluminum trihydroxide used in this study contained $20 \mathrm{wt}-\%$ moisture. The same trihydroxide source was used in the other A and B Tank simulants (AN-104, AW101, and AZ-102). The resulting aluminum levels are still within the range expected for actual $\mathrm{A}$ and $\mathrm{B}$ envelope tanks. However, the reported concentration of aluminum based on ICP-ES is considerably less than the $80 \%$ purity would support. Due to the small amount of free hydroxide, it is not surprising that the soluble aluminum concentration is so low. A small shift in the free hydroxide to a lower concentration due to $\mathrm{CO}_{2}$ absorption could significantly reduce the soluble aluminum level. Note that the aluminate concentration based upon titration does not agree with the ICP result $(0.03 \mathrm{M}$ versus $0.01 \mathrm{M}$ ).

In an effort to provide a more complete B simulant, the AZ-102 simulant was formulated to include many metals at trace concentrations. The following metals were based upon results from the 1989 core sample of AZ-102 (Gray et al. 1993): $\mathrm{Ag}, \mathrm{Ba}, \mathrm{Cd}, \mathrm{Cu}, \mathrm{Fe}, \mathrm{La}$, $\mathrm{Mg}, \mathrm{Mn}, \mathrm{Nd}, \mathrm{Ni}, \mathrm{Pb}, \mathrm{Si}, \mathrm{Sr}$, and $\mathrm{Zr}$. The neodymium concentration is expected to track the lanthanum concentration and would be a "less than" value. The chemical properties of silver in the simulant have already been discussed in regards to both the AN-107 and AN-104 simulants and photoreduction probably reduced the soluble silver concentration below the planned level. A contributing factor in the low solubility of these metals could be the relatively high concentration of oxalate present in the AZ-102 supernate. Many of these metals form salts with oxalic acid, which have low solubilities. In particular, calcium oxalate has very limited solubility and could explain the simulant feed having only $4.8 \mathrm{mg} / \mathrm{L}$ soluble calcium. 
Another contributing factor in the low solubilities of the metals could be the lack of complexing agents other than oxalate anion. The measured TOC for the recent AZ-102 sample was $6.04 \mathrm{~g} / \mathrm{L}$ (Hay 2000). The measured oxalate anion accounts for only $12 \%$ of the TOC. Additional organic characterization might provide a complexing agent sufficient to support the calcium ion concentration observed in the active sample.

The free hydroxide value reported for the AZ-102 simulant could be high due to an interference from the oxalate anion. Part of the analysis procedure involves addition of strontium nitrate to precipitate all of the carbonate prior to titration. Insufficient strontium nitrate addition due to the presence of oxalate might have produced a high hydroxide result and a low carbonate result.

The net impact of these differences on the goal of this study is expected to be small since all of the analytical results are within the range of expected conditions for Envelope B waste tanks. The goal of experiments with waste simulants is to develop knowledge about waste chemistry and to provide some prediction of potential problems. However, since waste characterization is not perfect, the simulant may not exactly duplicate the actual waste. Therefore, results from simulated waste experiments must be confirmed by actual waste studies. 
Table 8. AZ-102 Simulant Feed Composition.

\begin{tabular}{|c|c|c|c|c|c|}
\hline Components & Units & Found & Planned & \% of Target & Methods \\
\hline $\mathrm{Ag}$ & $\mathrm{mg} / \mathrm{L}$ & $<0.3$ & 6.9 & $<4$ & ICP-ES \\
\hline Al & $\mathrm{mg} / \mathrm{L}$ & 230 & 755 & 30 & ICP-ES \\
\hline B & $\mathrm{mg} / \mathrm{L}$ & 7.3 & 8.4 & 87 & ICP-ES \\
\hline $\mathrm{Ba}$ & $\mathrm{mg} / \mathrm{L}$ & 0.01 & 0.8 & 1 & ICP-ES \\
\hline $\mathrm{Ca}$ & $\mathrm{mg} / \mathrm{L}$ & 4.8 & 108.0 & 4 & ICP-ES \\
\hline $\mathrm{Cd}$ & $\mathrm{mg} / \mathrm{L}$ & 0.05 & 1.9 & 3 & ICP-ES \\
\hline $\mathrm{Cr}$ & $\mathrm{mg} / \mathrm{L}$ & 865 & 1011 & 86 & ICP-ES \\
\hline $\mathrm{Cs}$ & $\mathrm{mg} / \mathrm{L}$ & 1 & $\mathrm{NM}^{\mathrm{a}}$ & -- & AA \\
\hline $\mathrm{Cu}$ & $\mathrm{mg} / \mathrm{L}$ & 0.18 & 3.1 & 6 & ICP-ES \\
\hline $\mathrm{Fe}$ & $\mathrm{mg} / \mathrm{L}$ & 0.23 & 11.20 & 2 & ICP-ES \\
\hline $\mathrm{K}$ & $\mathrm{mg} / \mathrm{L}$ & 3150 & 3167 & 99 & AA \\
\hline $\mathrm{La}$ & $\mathrm{mg} / \mathrm{L}$ & $<0.06$ & 1.8 & $<3$ & ICP-ES \\
\hline $\mathrm{Mg}$ & $\mathrm{mg} / \mathrm{L}$ & $<0.09$ & 0.9 & $<10$ & ICP-ES \\
\hline $\mathrm{Mn}$ & $\mathrm{mg} / \mathrm{L}$ & $<0.009$ & 0.8 & $<1$ & ICP-ES \\
\hline Mo & $\mathrm{mg} / \mathrm{L}$ & 58 & 58 & 100 & ICP-ES \\
\hline $\mathrm{Na}$ & $\mathrm{mg} / \mathrm{L}$ & 58070 & 60900 & 95 & ICP-ES \\
\hline $\mathrm{Na}$ & $\mathrm{mg} / \mathrm{L}$ & 53000 & 60900 & 87 & $\mathrm{AA}$ \\
\hline $\mathrm{Nd}$ & $\mathrm{mg} / \mathrm{L}$ & $<0.3$ & 5.5 & $<5$ & ICP-ES \\
\hline $\mathrm{Ni}$ & $\mathrm{mg} / \mathrm{L}$ & $<0.06$ & 2.2 & $<3$ & ICP-ES \\
\hline $\mathrm{P}$ & $\mathrm{mg} / \mathrm{L}$ & 166 & 155 & 108 & ICP-ES \\
\hline $\mathrm{Pb}$ & $\mathrm{mg} / \mathrm{L}$ & $<0.6$ & 6 & $<10$ & ICP-ES \\
\hline $\mathrm{Si}$ & $\mathrm{mg} / \mathrm{L}$ & 121 & 559 & 22 & ICP-ES \\
\hline $\mathrm{Sr}$ & $\mathrm{mg} / \mathrm{L}$ & 0.05 & 0.20 & 23 & ICP-ES \\
\hline $\mathrm{Zr}$ & $\mathrm{mg} / \mathrm{L}$ & 0.43 & 4.30 & 10 & ICP-ES \\
\hline Chloride & $\mathrm{mg} / \mathrm{L}$ & 201 & 248 & 81 & $\mathrm{IC}$ \\
\hline Fluoride & $\mathrm{mg} / \mathrm{L}$ & 1111.0 & 1015.0 & 109 & $\mathrm{IC}$ \\
\hline Nitrate & $\mathrm{mg} / \mathrm{L}$ & 15360 & 16930 & 91 & $\mathrm{IC}$ \\
\hline Nitrite & $\mathrm{mg} / \mathrm{L}$ & 31050 & 30320 & 102 & $\mathrm{IC}$ \\
\hline Oxalate & $\mathrm{mg} / \mathrm{L}$ & 2671 & 2825 & 95 & $\mathrm{IC}$ \\
\hline Phosphate & $\mathrm{mg} / \mathrm{L}$ & 375 & 475 & 79 & $\mathrm{IC}$ \\
\hline Sulfate & $\mathrm{mg} / \mathrm{L}$ & 14848 & 16520 & 90 & $\mathrm{IC}$ \\
\hline TIC & $\mathrm{mg} / \mathrm{L}$ & 8946 & 6135 & 146 & $\mathrm{CO}_{2}$ Evolution \\
\hline TOC & $\mathrm{mg} / \mathrm{L}$ & 1052 & NM & -- & $\mathrm{CO}_{2}$ Evolution \\
\hline Carbonate (TIC) & $\mathrm{mg} / \mathrm{L}$ & 44696 & 30652 & 146 & Calc. from TIC \\
\hline Aluminate & Molar & 0.030 & 0.028 & 107 & Titration \\
\hline Carbonate & Molar & 0.464 & 0.511 & 91 & Titration \\
\hline Free $\mathrm{OH}$ & Molar & 0.196 & 0.109 & 180 & Titration \\
\hline \multicolumn{6}{|c|}{ NM = Not Measured. } \\
\hline
\end{tabular}


WSRC-TR-2000-00319

SRT-RPP-2000-00020

Revision 0

\subsubsection{C-106 Caustic Leachate Simulant}

Current plans for processing Envelope D sludge includes caustic leaching with 3-M sodium hydroxide to reduce the aluminum content in the Envelope D sludge. The C-106 caustic leachate simulant recipe is based on a 3-M sodium hydroxide leachate of C-106 sludge (Brooks et al. 1997). Since carbonate was not measured on the caustic leachate, carbonate was used to obtain a charge balance. This produces a simulant with a substantial amount of carbonate. A review of the information on the solids from C-106 suggests that carbonate would leach from the solids and is appropriate for this matrix. The planned and as produced composition is presented in Table 9. The density of the simulant was $1.199 \mathrm{~g} / \mathrm{mL}$ and contained $21.8 \mathrm{wt}-\%$ total solids.

There was $>20 \%$ deviation in concentrations between the "found" and "planned" concentration of the following analytes: $\mathrm{Al}, \mathrm{NO}_{3}{ }^{-}, \mathrm{TIC}, \mathrm{Al}(\mathrm{OH})_{4}{ }^{-}$. The differences can be categorized as being due to: (1) the starting reagent and (2) analytical problems. A brief summary for some of the causes that may be responsible for the discrepancies between the planned and found concentrations is presented in Table 2.

The aluminum value as reported by ICP-ES and by titration was lower than planned because the aluminum trihydroxide used in this study contained $20 \mathrm{wt}-\%$ moisture. The same trihydroxide source was used in the A and B Tank simulants (AN-104, AW-101, and AZ-102) and in the other caustic leachate simulant. The resulting aluminum levels are still within the range expected for actual Envelope A and B tanks. Since the caustic leachate is a relatively simple caustic solution, it is not surprising that the amount of aluminum based on ICP-ES is so close to the purity of the starting aluminum reagent.

The cause for a lower than expected analytical result for nitrate is not known. The relatively low ionic strength of the caustic leachate simulant should allow complete dissolution of the sodium nitrate used to make the simulant. The caustic leachate simulant was not observed to have produced any solids when it was filtered. One possibility is that the sodium nitrate used may have absorbed some moisture. The absorption of a molecule of water per molecule of sodium nitrate would reduce the nitrate level by about $18 \%$ which is close to the amount that was missing. In any case, nitrate is not expected to be a significant portion of the caustic leachate or to participate in solubility problems during waste mixing.

Apparent analytical problems are represented by the results for aluminate and TIC. The aluminate result is only $78 \%$ of the ICP-ES value. Aluminate is calculated by taking the difference between two titrations and is subject to increased error when both results are large and nearly equal. The TIC result may be a transcription error since the TOC value is large (no TOC present) and the TIC value is small. However, switching the results gives a TIC value, which does not agree with the carbonate value from titration. The cause for the low TIC and the carbonate (TIC) values are not known. It is known that the carbonate was not inadvertently left out of the recipe because the concentrations of $\mathrm{Na}$, 
the cation associated with the carbonate salt, existed in the simulant at approximately the targeted concentrations.

The net impact of these differences on the goal of this study is expected to be small since all of the analytical results are within the range of expected conditions for Envelope B waste tanks. The goal of experiments with waste simulants is to develop knowledge about waste chemistry and to provide some prediction of potential problems. However, since waste characterization is not perfect, the simulant may not exactly duplicate the actual waste. Therefore, results from simulated waste experiments must be confirmed by actual waste studies.

Table 9. Tank C-106 Caustic Leachate Simulant Feed Composition.

\begin{tabular}{|c|c|c|c|c|c|}
\hline Component & Units & Found & Planned & \% of Target & Methods \\
\hline $\mathrm{Ag}$ & $\mathrm{mg} / \mathrm{L}$ & $<0.3$ & $\mathrm{NM}^{\mathrm{a}}$ & $\overline{--}$ & ICP-ES \\
\hline $\mathrm{Al}$ & $\mathrm{mg} / \mathrm{L}$ & 2460 & 3100 & 79 & ICP-ES \\
\hline B & $\mathrm{mg} / \mathrm{L}$ & 68 & 67 & 101 & ICP-ES \\
\hline $\mathrm{Ba}$ & $\mathrm{mg} / \mathrm{L}$ & 14.6 & NM & -- & ICP-ES \\
\hline $\mathrm{Ca}$ & $\mathrm{mg} / \mathrm{L}$ & 3.3 & NM & -- & ICP-ES \\
\hline $\mathrm{Cr}$ & $\mathrm{mg} / \mathrm{L}$ & 49 & 58 & 85 & ICP-ES \\
\hline Cs & $\mathrm{mg} / \mathrm{L}$ & 0.7 & NM & -- & AA \\
\hline $\mathrm{Cu}$ & $\mathrm{mg} / \mathrm{L}$ & 0.06 & NM & -- & ICP-ES \\
\hline $\mathrm{Fe}$ & $\mathrm{mg} / \mathrm{L}$ & 0.24 & NM & -- & ICP-ES \\
\hline $\mathrm{K}$ & $\mathrm{mg} / \mathrm{L}$ & 2.4 & NM & -- & $\mathrm{AA}$ \\
\hline $\mathrm{Na}$ & $\mathrm{mg} / \mathrm{L}$ & 105670 & 110000 & 96 & ICP-ES \\
\hline $\mathrm{Na}$ & $\mathrm{mg} / \mathrm{L}$ & 102470 & 110000 & 93 & AA \\
\hline $\mathrm{Nd}$ & $\mathrm{mg} / \mathrm{L}$ & $<0.3$ & NM & -- & ICP-ES \\
\hline $\mathrm{Ni}$ & $\mathrm{mg} / \mathrm{L}$ & 0.06 & NM & -- & ICP-ES \\
\hline $\mathrm{P}$ & $\mathrm{mg} / \mathrm{L}$ & 125 & 109 & 115 & ICP-ES \\
\hline $\mathrm{Pb}$ & $\mathrm{mg} / \mathrm{L}$ & 26 & 31 & 85 & ICP-ES \\
\hline $\mathrm{Si}$ & $\mathrm{mg} / \mathrm{L}$ & 303 & 295 & 103 & ICP-ES \\
\hline $\mathrm{Zn}$ & $\mathrm{mg} / \mathrm{L}$ & 0.48 & NM & -- & ICP-ES \\
\hline Chloride & $\mathrm{mg} / \mathrm{L}$ & 105 & NM & -- & $\mathrm{IC}$ \\
\hline Fluoride & $\mathrm{mg} / \mathrm{L}$ & $<20$ & NM & -- & IC \\
\hline Nitrate & $\mathrm{mg} / \mathrm{L}$ & 241 & 335 & 72 & IC \\
\hline Nitrite & $\mathrm{mg} / \mathrm{L}$ & 6589 & 6850 & 96 & $\mathrm{IC}$ \\
\hline Oxalate & $\mathrm{mg} / \mathrm{L}$ & 698 & 2500 & 28 & IC \\
\hline Phosphate & $\mathrm{mg} / \mathrm{L}$ & 303 & 335 & 90 & $\mathrm{IC}$ \\
\hline Sulfate & $\mathrm{mg} / \mathrm{L}$ & 1570 & 1800 & 87 & IC \\
\hline TIC & $\mathrm{mg} / \mathrm{L}$ & 3 & 10029 & 0 & \\
\hline TOC & $\mathrm{mg} / \mathrm{L}$ & 18716 & NM & -- & \\
\hline Carbonate (TIC) & $\mathrm{mg} / \mathrm{L}$ & 13 & 50110 & 0 & Calc. from TIC \\
\hline Aluminate & Molar & 0.070 & 0.115 & 61 & Titration \\
\hline Carbonate & Molar & 0.881 & 0.835 & 106 & Titration \\
\hline Free $\mathrm{OH}$ & Molar & 2.651 & 2.700 & 98 & Titration \\
\hline
\end{tabular}




\subsubsection{AZ-102 Leachate Simulant}

The AZ-102 caustic leachate simulant is based on the resulting supernate produced by leaching AZ-102 sludge with 3-M sodium hydroxide (Herting 1995). Charge balancing the recipe is based on hydroxide since a measured hydroxide concentration was not available for the leachate. Table 10 provides the "found" (actual) and "planned" composition for the simulant feed. The density of the AZ-102 leachate simulant was $1.112 \mathrm{~g} / \mathrm{mL}$ and the total solids in the simulant was $13.6 \mathrm{wt}-\%$.

There was $>20 \%$ deviation in concentrations between the "found" and "planned" concentration of the following analytes: $\mathrm{Al}, \mathrm{F}, \mathrm{NO}_{3}{ }^{-}, \mathrm{PO}_{4}{ }^{3-}, \mathrm{TIC}, \mathrm{Al}(\mathrm{OH})_{4}{ }^{-}$, and $\mathrm{CO}_{3}{ }^{2-}$. The differences can be categorized as being due to: (1) the starting reagent and (2) analytical problems. A brief summary for some of the causes that may be responsible for the discrepancies between the planned and found concentrations is presented in Table 2 .

The aluminum value as reported by ICP-ES and by titration was lower than planned because the aluminum trihydroxide used in this study had a purity of only $80 \%$, the remaining $20 \%$ consisted of water. The same trihydroxide source was used in the A and B Tank simulants (AN-104, AW-101, and AZ-102) and in the other caustic leachate simulant. The resulting aluminum levels are still within the range expected for actual Envelope A and B tanks. Since the caustic leachate is a relatively simple caustic solution, it is not surprising that the amount of aluminum based on ICP-ES is so close to the purity of the starting aluminum reagent.

The cause for the lower than expected analytical result for nitrate is not known. The relatively low ionic strength of the caustic leachate simulant should allow complete dissolution of the sodium nitrate used to make the simulant. The caustic leachate simulant was not observed to have produced any solids when it was filtered. One possibility is that the sodium nitrate used may have absorbed some moisture. The absorption of a molecule of water per molecule of sodium nitrate would reduce the nitrate level by about $18 \%$, which is close to the amount that was missing. In any case, nitrate is not expected to be a significant portion of the caustic leachate or to participate much in solubility problems during waste mixing.

Apparent analytical problems are represented by the results for fluoride, phosphate, aluminate and TIC. The phosphate result from the IC does not agree with the phosphorus result from ICP-ES. Since aluminate is based on a difference between two titrations and the planned aluminate concentration is so small, the production of a less than result is not surprising. The TIC result may be a transcription error since the TOC value is large (no TOC present) and the TIC value is small. However, switching the results gives a TIC value, which does not agree with the planned carbonate concentration of 0.195 molar. The cause for the low TIC value is not known. It is known that the carbonate was not inadvertently left out of the recipe because the concentrations of $\mathrm{Na}$, the cation associated 
with the carbonate salt, existed in the simulant at approximately the targeted concentrations.

The net impact of these differences on the goal of this study is expected to be small since all of the analytical results are within the range of expected conditions for Envelope B waste tanks. The goal of experiments with waste simulants is to develop knowledge about waste chemistry and to provide some prediction of potential problems. However, since waste characterization is not perfect, the simulant may not exactly duplicate the actual waste. Therefore, results from simulated waste experiments must be confirmed by actual waste studies. 
Table 10. AZ-102 Caustic Leachate Simulant Composition.

\begin{tabular}{|c|c|c|c|c|c|}
\hline Component & Units & Found & Planned & $\%$ of Target & Methods \\
\hline $\mathrm{Al}$ & $\mathrm{mg} / \mathrm{L}$ & 1195 & 1540 & 78 & ICP-ES \\
\hline $\mathrm{B}$ & $\mathrm{mg} / \mathrm{L}$ & 0.25 & $\mathrm{NM}^{\mathrm{a}}$ & -- & ICP-ES \\
\hline $\mathrm{Ba}$ & $\mathrm{mg} / \mathrm{L}$ & 0.01 & NM & -- & ICP-ES \\
\hline $\mathrm{Ca}$ & $\mathrm{mg} / \mathrm{L}$ & 2.2 & NM & -- & ICP-ES \\
\hline $\mathrm{Cr}$ & $\mathrm{mg} / \mathrm{L}$ & 160 & 194 & 82 & ICP-ES \\
\hline Cs & $\mathrm{mg} / \mathrm{L}$ & 0.2 & NM & -- & AA \\
\hline $\mathrm{Cu}$ & $\mathrm{mg} / \mathrm{L}$ & $<0.05$ & NM & -- & ICP-ES \\
\hline $\mathrm{Fe}$ & $\mathrm{mg} / \mathrm{L}$ & 0.19 & NM & -- & ICP-ES \\
\hline $\mathrm{K}$ & $\mathrm{mg} / \mathrm{L}$ & 920 & 904 & 102 & AA \\
\hline $\mathrm{La}$ & $\mathrm{mg} / \mathrm{L}$ & $<0.06$ & NM & -- & ICP-ES \\
\hline $\mathrm{Li}$ & $\mathrm{mg} / \mathrm{L}$ & $<0.1$ & NM & -- & ICP-ES \\
\hline $\mathrm{Mg}$ & $\mathrm{mg} / \mathrm{L}$ & $<0.09$ & NM & -- & ICP-ES \\
\hline $\mathrm{Mn}$ & $\mathrm{mg} / \mathrm{L}$ & 0.03 & NM & -- & ICP-ES \\
\hline Mo & $\mathrm{mg} / \mathrm{L}$ & 14 & 14 & 99 & ICP-ES \\
\hline $\mathrm{Na}$ & $\mathrm{mg} / \mathrm{L}$ & 57070 & 59200 & 96 & ICP-ES \\
\hline $\mathrm{Na}$ & $\mathrm{mg} / \mathrm{L}$ & 57320 & 59200 & 97 & AA \\
\hline $\mathrm{Nd}$ & $\mathrm{mg} / \mathrm{L}$ & $<0.3$ & $\mathrm{NM}$ & -- & ICP-ES \\
\hline $\mathrm{Ni}$ & $\mathrm{mg} / \mathrm{L}$ & $<0.06$ & NM & -- & ICP-ES \\
\hline $\bar{P}$ & $\mathrm{mg} / \mathrm{L}$ & 211 & 194 & 109 & ICP-ES \\
\hline $\mathrm{Si}$ & $\mathrm{mg} / \mathrm{L}$ & 1.4 & $\mathrm{NM}$ & -- & ICP-ES \\
\hline $\mathrm{Sr}$ & $\mathrm{mg} / \mathrm{L}$ & 0.03 & $\mathrm{NM}$ & -- & ICP-ES \\
\hline Chloride & $\mathrm{mg} / \mathrm{L}$ & 117 & 22 & 532 & $\mathrm{IC}$ \\
\hline Fluoride & $\mathrm{mg} / \mathrm{L}$ & 100.0 & 136 & 74 & $\mathrm{IC}$ \\
\hline Formate & $\mathrm{mg} / \mathrm{L}$ & $<100$ & $\mathrm{NM}$ & -- & $\mathrm{IC}$ \\
\hline Nitrate & $\mathrm{mg} / \mathrm{L}$ & 4515 & 5940 & 76 & $\mathrm{IC}$ \\
\hline Nitrite & $\mathrm{mg} / \mathrm{L}$ & 7393 & 7930 & 93 & $\mathrm{IC}$ \\
\hline Oxalate & $\mathrm{mg} / \mathrm{L}$ & $<100$ & $\mathrm{NM}$ & -- & $\mathrm{IC}$ \\
\hline Phosphate & $\mathrm{mg} / \mathrm{L}$ & 770 & 594 & 130 & IC \\
\hline Sulfate & $\mathrm{mg} / \mathrm{L}$ & 4844 & 4850 & 100 & IC \\
\hline TIC & $\mathrm{mg} / \mathrm{L}$ & $<200$ & 2340 & $<8.5$ & $\mathrm{CO}_{2}$ Evolution \\
\hline TOC & $\mathrm{mg} / \mathrm{L}$ & 8394 & $\mathrm{NM}$ & - & $\mathrm{CO}_{2}$ Evolution \\
\hline Carbonate (TIC) & $\mathrm{mg} / \mathrm{L}$ & $\mathrm{NM}$ & 11690 & -- & Calc. from TIC \\
\hline Aluminate & Molar & $<0.01$ & 0.057 & $<17.5$ & Titration \\
\hline Carbonate & Molar & 0.148 & 0.195 & 76 & Titration \\
\hline Free $\mathrm{OH}$ & Molar & 1.820 & 1.75 & 104 & Titration \\
\hline
\end{tabular}




\subsection{Dilution Experiment}

The reader is directed to Kaplan et al. (2000; SRT-RPP-2000-00016) for discussion, details and conclusions concerning this experiment. The analytical results presented in this section are for general information and the final report (Kaplan et al. 2000) should be consulted before using or trying to interpret these results.

These tests were added because no turbidity was visually observed (no turbidity meter was used) when active feed samples were mixed, contrary to the results from the simulant mixing study. This inconsistency was believed to be due to differences in feed concentrations; the simulants were more concentrated than the active feed samples. Mixing tests were conducted with simulants that were diluted to the same sodium molar concentrations as the corresponding active feed samples. The dilute feed solutions were combined in the same ratios as were used in the active mixing study, i.e., 3/30 on a volume basis 


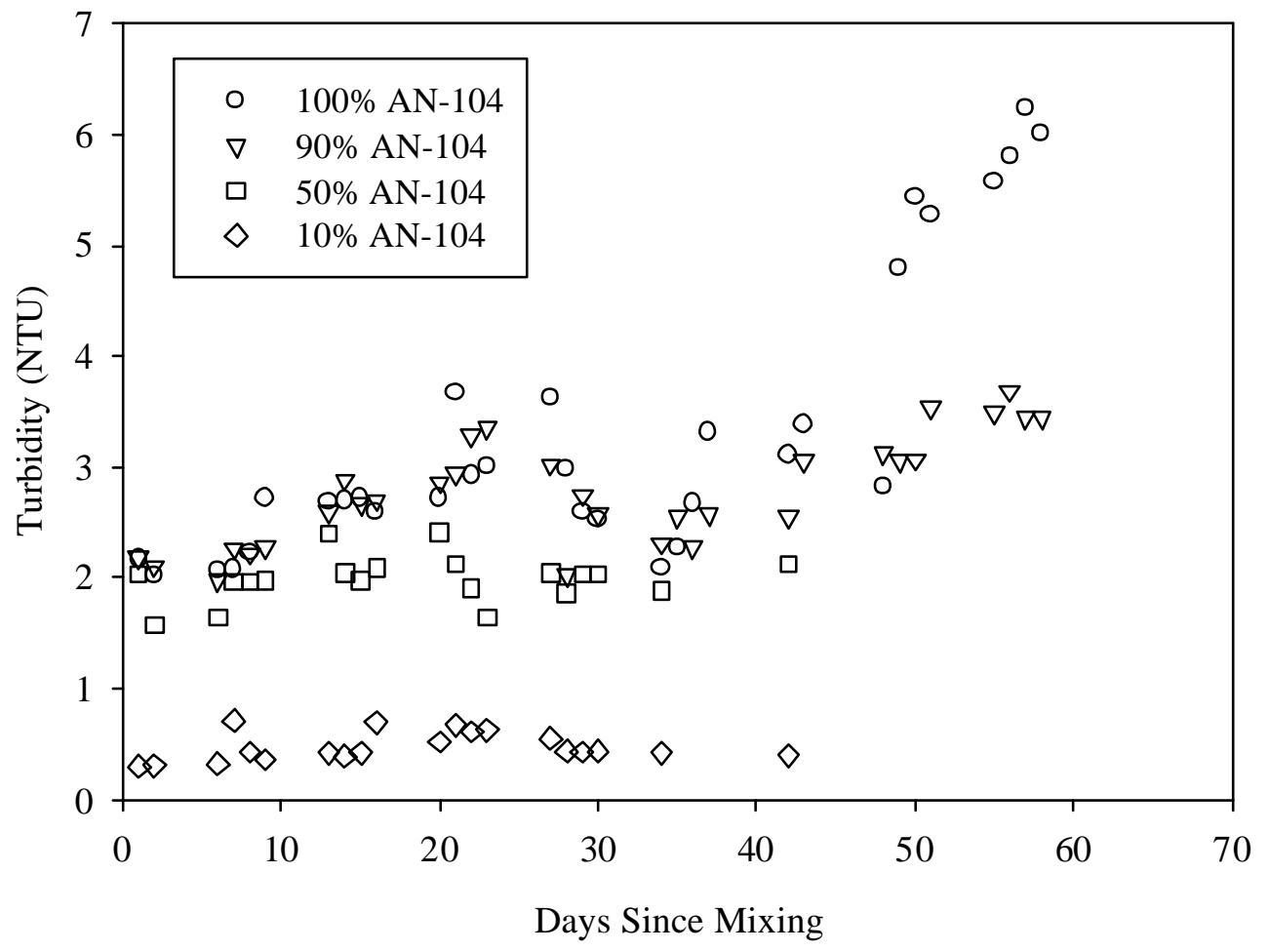

Figure 2. Turbidity of AN-104 Diluted with $0.01 \mathrm{M} \mathrm{NaOH}$. 


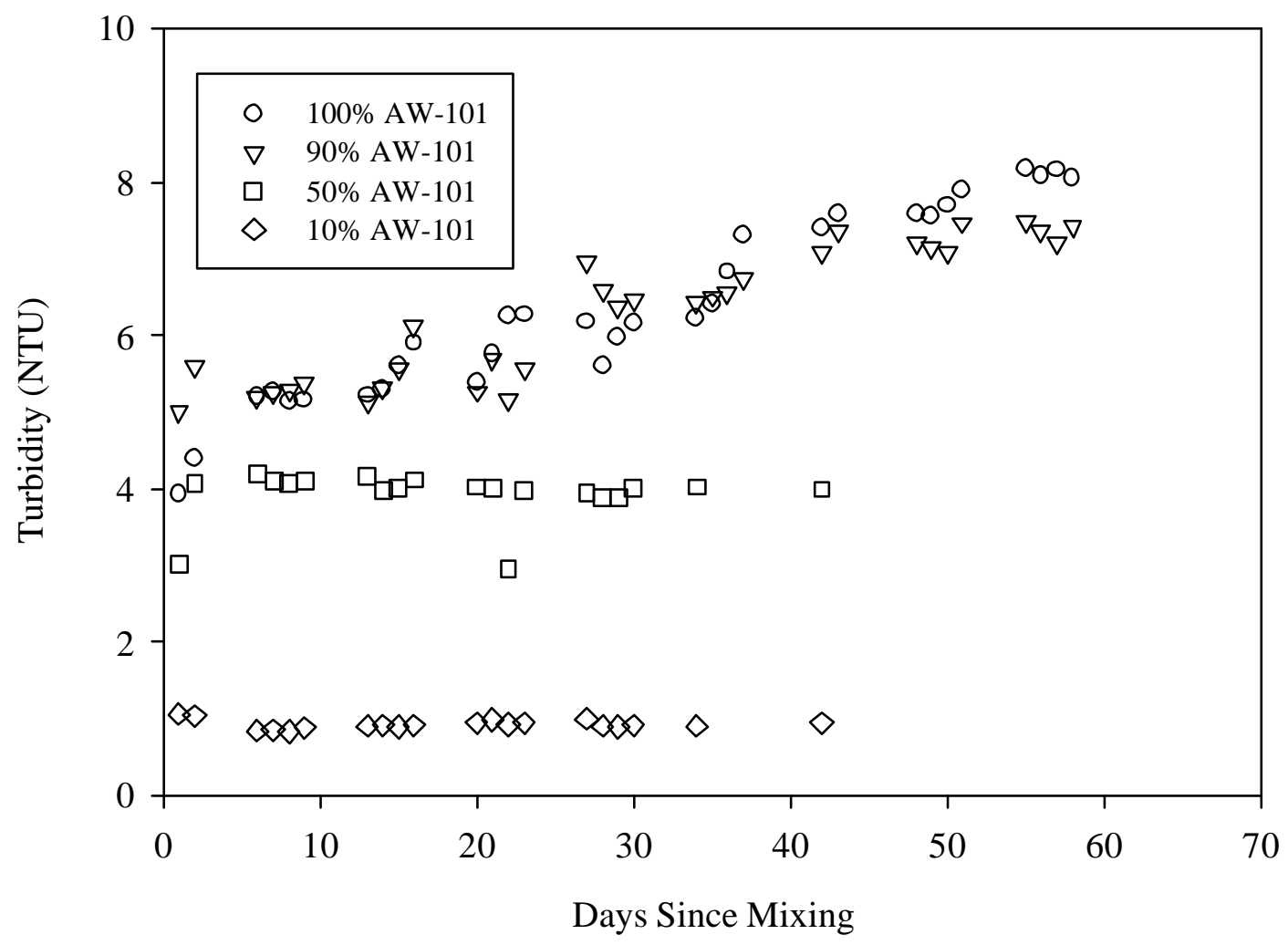

Figure 3. Turbidity of AW-101 Diluted with $0.01 \mathrm{M} \mathrm{NaOH}$. 


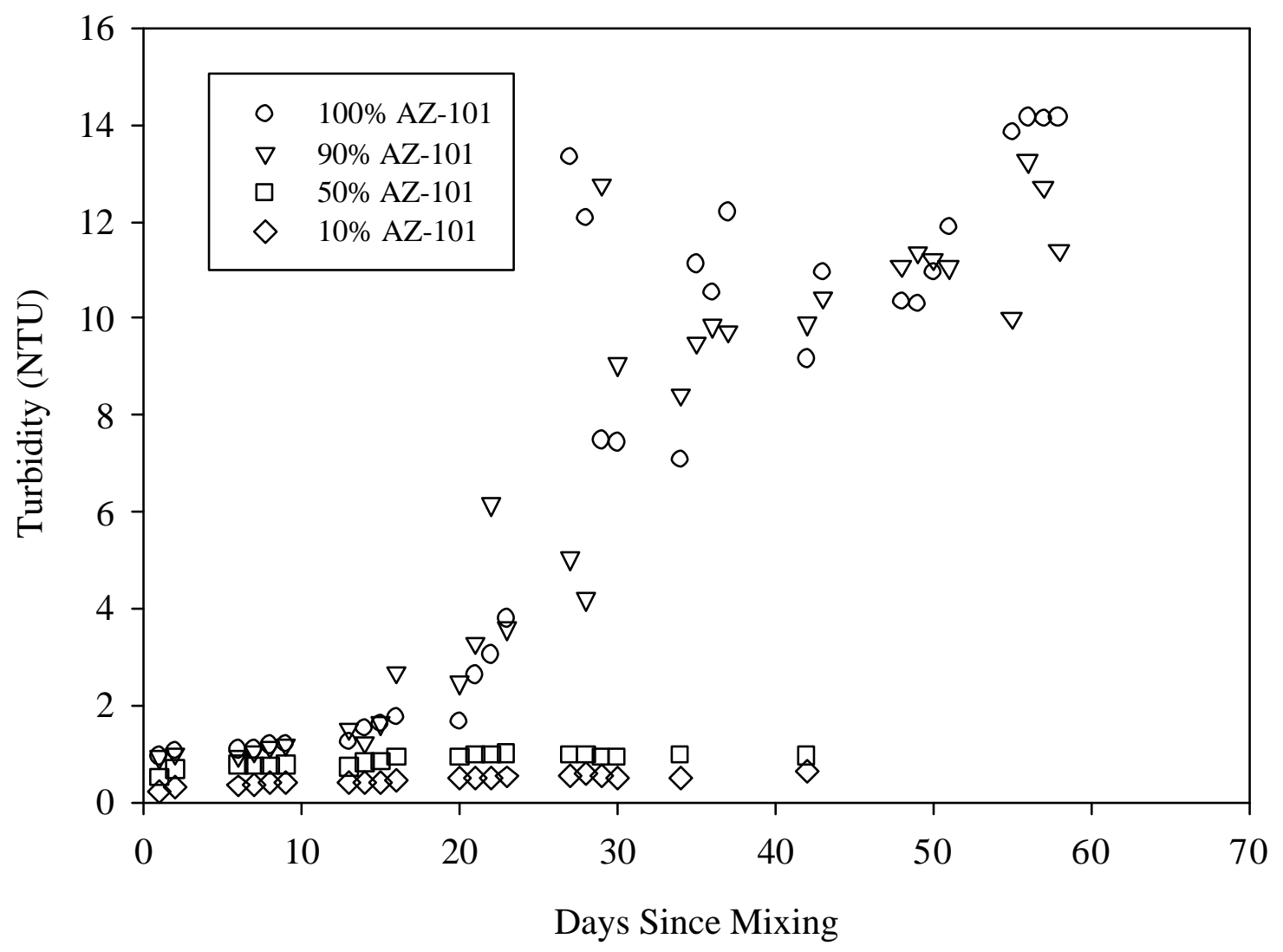

Figure 4. Turbidity of AZ-101 Diluted with $0.01 \mathrm{M} \mathrm{NaOH}$. 


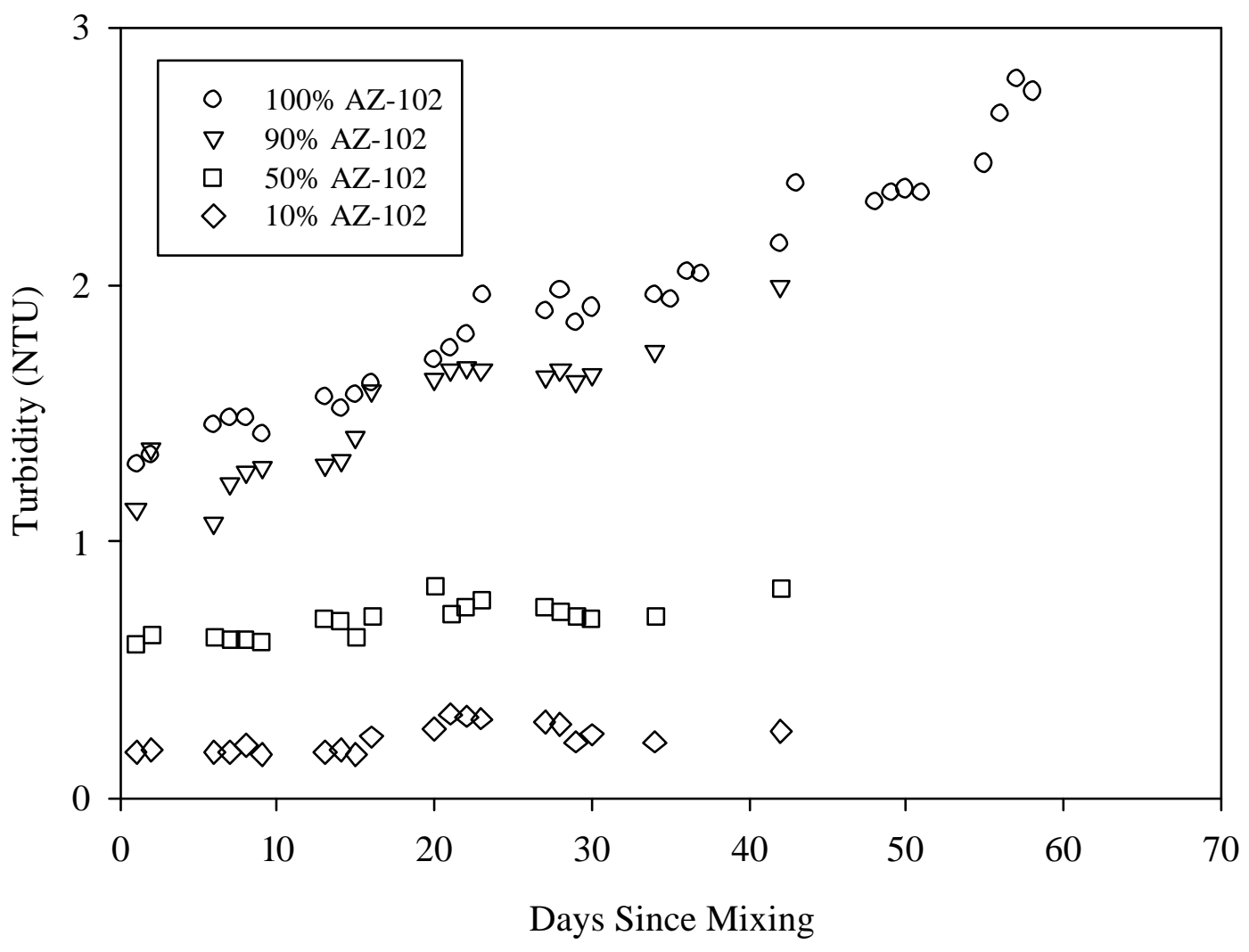

Figure 5. Turbidity of AZ-102 Diluted with $0.01 \mathrm{M} \mathrm{NaOH}$. 


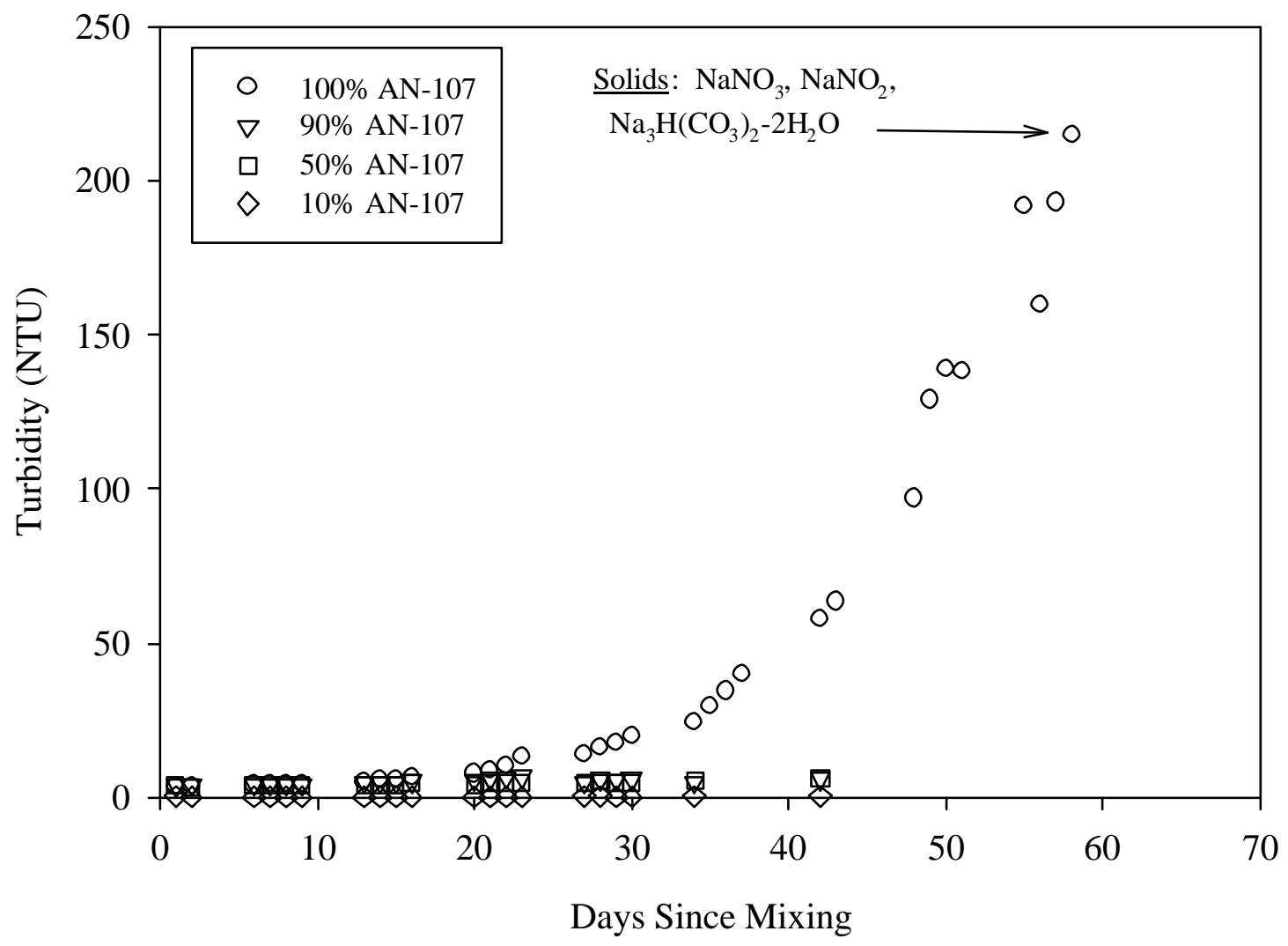

Figure 6. Turbidity of AN-107 Diluted with $0.01 \mathrm{M} \mathrm{NaOH}$. 
Table 11. Turbidity and Solids Concentrations (Collected on a 0.45-Micron Filter) At the End of the 60-Day Equilibration Period.

\begin{tabular}{|c|c|c|}
\hline Sample Description & Solids Concentration $^{\mathrm{a}}$ & Turbidity \\
\hline & $(\mathrm{mg} / \mathrm{L})$ & (NTU) \\
\hline $100 \%$ AN-104 & 1029 & 6.01 \\
\hline $100 \%$ AW-101 & 1288 & 8.05 \\
\hline $100 \%$ AZ-101 & 681 & 14.14 \\
\hline $100 \%$ AZ-102 & 299 & 2.75 \\
\hline $100 \%$ AN-107 & $14869^{b}$ & 215.0 \\
\hline \multicolumn{3}{|c|}{$\begin{array}{l}\text { a Solids concentrations are biased high because of the formation of evaporates } \\
\text { during the process of retrieving the solids via filtration. } \\
\text { b Not all of the solids could be transferred from the } 250 \text {-mL flask to the } 0.45- \\
\mu m \text { filter to measure solids concentration. A majority of the solids remained } \\
\text { attached to the flask; thus, the reported solids concentration under estimates the } \\
\text { true solids concentration for this feed. }\end{array}$} \\
\hline
\end{tabular}




\subsection{Envelope Mixing Experiment}

The reader is directed to Kaplan et al. (2000; SRT-RPP-2000-00016) for discussion, details and conclusions concerning this experiment. The analytical results presented in this section are for general information and the final report (Kaplan et al. 2000) should be consulted before using or trying to interpret these results.

Table 12. Chemical Composition of Selected Filtrates from Envelope Mixing Study: ICP-ES (mg/L).

\begin{tabular}{|c|c|c|c|c|c|c|c|}
\hline & $\begin{array}{c}100 \% \text { AN- } \\
104\end{array}$ & $\begin{array}{c}100 \% \text { AZ- } \\
101\end{array}$ & $\begin{array}{c}100 \% \text { AN- } \\
107\end{array}$ & $\begin{array}{l}10 \% \text { AZ-101 } \\
90 \% \text { AN-107 }\end{array}$ & $\begin{array}{l}50 \% \text { AZ-101 } \\
50 \% \text { AN-107 }\end{array}$ & $\begin{array}{l}10 \% \text { AN-107 } \\
90 \% \text { AN-104 }\end{array}$ & $\begin{array}{l}50 \% \text { AN-107 } \\
50 \% \text { AN-104 }\end{array}$ \\
\hline $\mathrm{Al}$ & 16952 & 7752 & 184 & 317 & 4040 & 15950 & 6720 \\
\hline B & 33 & $<0.21$ & 37 & 31 & 16 & 31 & 25 \\
\hline $\mathrm{Ba}$ & 5.6 & 0.02 & 0.03 & 0.026 & 0.033 & 0.049 & 0.045 \\
\hline $\mathrm{Ca}$ & 2.8 & 3.7 & 113 & 116 & 71 & 15.0 & 52 \\
\hline $\mathrm{Cd}$ & $<0.02$ & $<0.014$ & $<0.014$ & $<0.014$ & $<0.014$ & $<0.014$ & $<0.014$ \\
\hline Co & $<0.044$ & $<0.044$ & $<0.044$ & $<0.044$ & $<0.044$ & $<0.044$ & $<0.044$ \\
\hline $\mathrm{Cr}$ & 204 & 648 & 154 & 186 & 411 & 198 & 134 \\
\hline $\mathrm{Cu}$ & 0.14 & 0.14 & 32 & 27 & 15 & 2.7 & 11.5 \\
\hline $\mathrm{Fe}$ & 0.31 & 0.46 & 1660 & 1406 & 734 & 43 & 471 \\
\hline $\mathrm{La}$ & $<0.06$ & $<0.06$ & 43 & 36 & 21 & 2.4 & 14.4 \\
\hline $\mathrm{Li}$ & 0.26 & 0.18 & 0.15 & 0.12 & $<0.1$ & $<0.1$ & $<0.1$ \\
\hline $\mathrm{Mg}$ & $<0.09$ & $<0.09$ & 20 & 2.33 & 0.45 & $<0.084$ & $<0.084$ \\
\hline $\mathrm{Mn}$ & $<0.009$ & 0.11 & 569 & 482 & 217 & 4.9 & 110 \\
\hline Mo & 49 & $<0.1$ & 37 & 31 & 18 & 47 & 32 \\
\hline $\mathrm{Na}$ & 164670 & 104670 & 193972 & 171941 & 148290 & 169578 & 136743 \\
\hline $\mathrm{Ni}$ & 0.41 & 0.34 & 517 & 429 & 256 & 51 & 191 \\
\hline $\mathrm{P}$ & 444 & 546 & 433 & 402 & 471 & 418 & 321 \\
\hline $\mathrm{Pb}$ & $<0.6$ & $<0.06$ & 381 & 319 & 179 & 42 & 131 \\
\hline $\mathrm{Si}$ & 169 & 5.3 & 1.6 & 1.9 & 3.0 & 145 & 57 \\
\hline $\mathrm{Sn}$ & $<0.26$ & $<0.26$ & $<0.26$ & $<0.26$ & $<0.26$ & $<0.26$ & $<0.26$ \\
\hline $\mathrm{Sr}$ & 0.09 & 0.07 & 1.20 & 1.04 & 0.66 & 0.14 & 0.42 \\
\hline $\mathrm{Ti}$ & 0.15 & $<0.14$ & $<0.14$ & $<0.14$ & $<0.14$ & $<0.14$ & $<0.14$ \\
\hline $\mathrm{V}$ & $<0.13$ & $<0.13$ & $<0.13$ & $<0.13$ & $<0.13$ & $<0.13$ & $<0.13$ \\
\hline $\mathrm{Zn}$ & 3.4 & 4.3 & 45 & 37 & 21.5 & 7.32 & 15.9 \\
\hline $\mathrm{Zr}$ & $<0.05$ & 0.32 & 47 & 39 & 23 & 3.85 & 17 \\
\hline $\mathrm{S}$ & 1896 & 5247 & 2675 & 3010 & 4380 & 2480 & 2007 \\
\hline
\end{tabular}


Table 13. Chemical Composition of Selected Filtrates from Envelope Mixing Study: Other Methods (mg/L).

\begin{tabular}{|c|c|c|c|c|c|c|c|c|}
\hline & $\begin{array}{c}\text { Analytical } \\
\text { Method }\end{array}$ & $\begin{array}{c}100 \% \text { AN- } \\
104\end{array}$ & $\begin{array}{c}100 \% \mathrm{AZ}- \\
101\end{array}$ & $\begin{array}{c}100 \% \mathrm{AN}- \\
107\end{array}$ & $\begin{array}{c}10 \% \mathrm{AZ}- \\
101 \\
90 \% \mathrm{AN}- \\
107\end{array}$ & $\begin{array}{c}50 \% \mathrm{AZ}- \\
101 \\
50 \% \mathrm{AN}- \\
107\end{array}$ & $\begin{array}{c}10 \% \mathrm{AN}- \\
107 \\
90 \% \mathrm{AN}- \\
104\end{array}$ & $\begin{array}{c}50 \% \text { AN- } \\
107 \\
50 \% \text { AN- } \\
104 \\
\end{array}$ \\
\hline Chloride & $\mathrm{IC}$ & 5861 & 182 & 2978 & 2750 & 2329 & 5337 & 3174 \\
\hline Fluoride & IC & $<200$ & 760 & 3813 & 3277 & 2780 & 199 & 1162 \\
\hline Nitrate & $\mathrm{IC}$ & 85960 & 60330 & 259453 & 219868 & 162218 & 115107 & 106190 \\
\hline Nitrite & IEC/IPC & 62630 & 61770 & 63578 & 58431 & 70835 & 62579 & 41678 \\
\hline Phosphate & IC & 868 & 1318 & 4684 & 4312 & 3790 & 1134 & 12261 \\
\hline Sulfate & $\mathrm{IC}$ & 5744 & 15740 & 9470 & 9542 & 13753 & 7529 & 5608 \\
\hline $\mathrm{K}$ & AA & 4320 & 4690 & 1930 & 2005 & 3266 & 4020 & 2240 \\
\hline $\begin{array}{c}\text { Free OH } \\
\text { (molarity) }\end{array}$ & Titration & 1.906 & 0.463 & $<0.02$ & $<0.02$ & 0.2275 & 1.6524 & 0.4568 \\
\hline Organic $\mathrm{C}$ & TIC/TOC & 3628 & 365 & 21640 & 18476 & 11102 & 3008 & 8878 \\
\hline Inorganic $\mathrm{C}$ & TIC/TOC & 12314 & 8466 & 25400 & 23200 & 20720 & 32960 & 23020 \\
\hline Formate & $\mathrm{IC}$ & $<100$ & $<100$ & 12207 & 10184 & 6504 & 1322 & 3746 \\
\hline Oxalate & $\mathrm{IC}$ & 160 & $<100$ & 619 & 572 & 391 & 253 & 226 \\
\hline Citrate & IEC & NBLR & NBLR & 7925 & 6260 & 4782 & 234 & 1800 \\
\hline Glycolate & IEC & 1290 & 1222 & 18225 & 15283 & 9384 & 1994 & 6706 \\
\hline Formate & IEC & 916 & 968 & 10920 & 9198 & 6107 & 1581 & 4547 \\
\hline Acetate & IEC & NBLR & NBLR & 1267 & 1193 & 1087 & NBLR & NBLR \\
\hline HEDTA & IPC & NM & $\mathrm{NM}$ & 10749 & 8629 & 5502 & 1033 & 4231 \\
\hline EDTA & IPC & NM & $\mathrm{NM}$ & 2109 & 1653 & 938 & 248 & 806 \\
\hline
\end{tabular}




\subsubsection{Full-strength Envelope Mixing Experiment}

\subsubsection{AZ-101 and AN-107 Full Strength Mixtures}

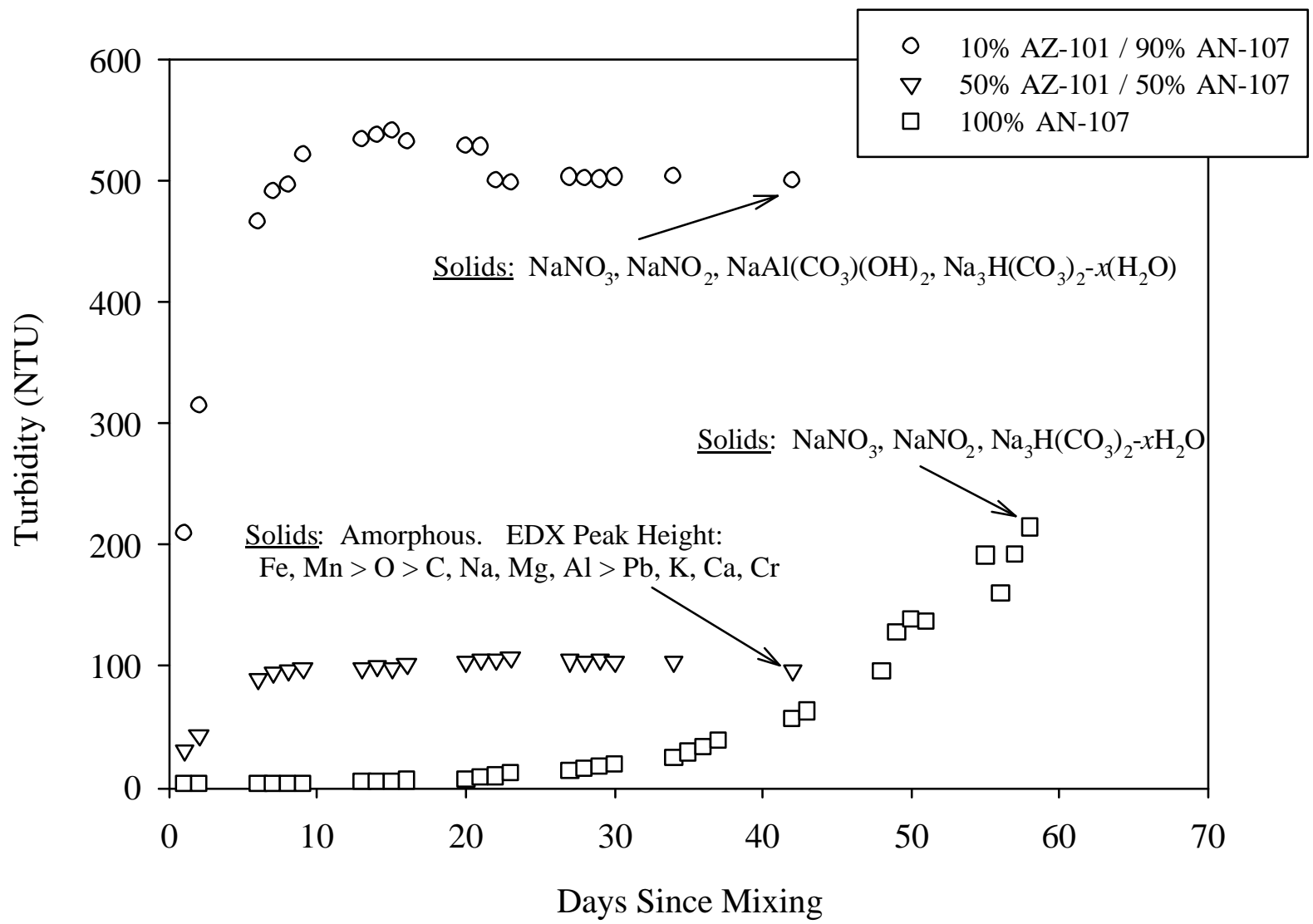

Figure 7. Turbidity and Solid Phases Based on XRD and SEM in Mixtures of AZ-101 and $\mathrm{AN}-107$. 

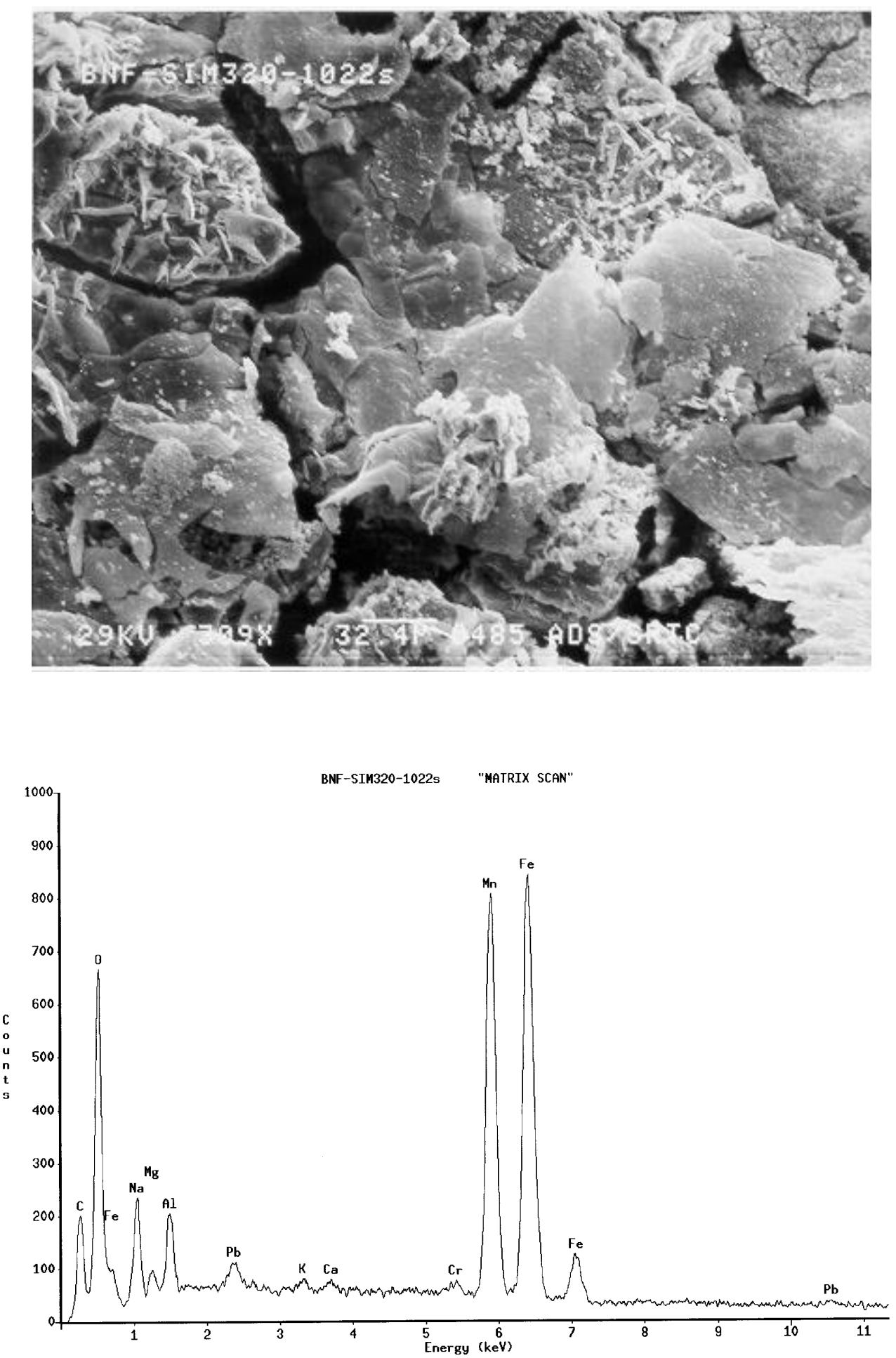

Figure 8. SEM image and EDX spectrum of solids recovered at the end of the 50\% AZ$101 / 50 \%$ AN-107 mixtures. The scale bar in the SEM image represents 32.4- $\mu \mathrm{m}$. The EDX spot size was about the same as the entire SEM image, thus it represents an average. 


\subsubsection{AN-104 and AN-107 Full Strength Mixtures}

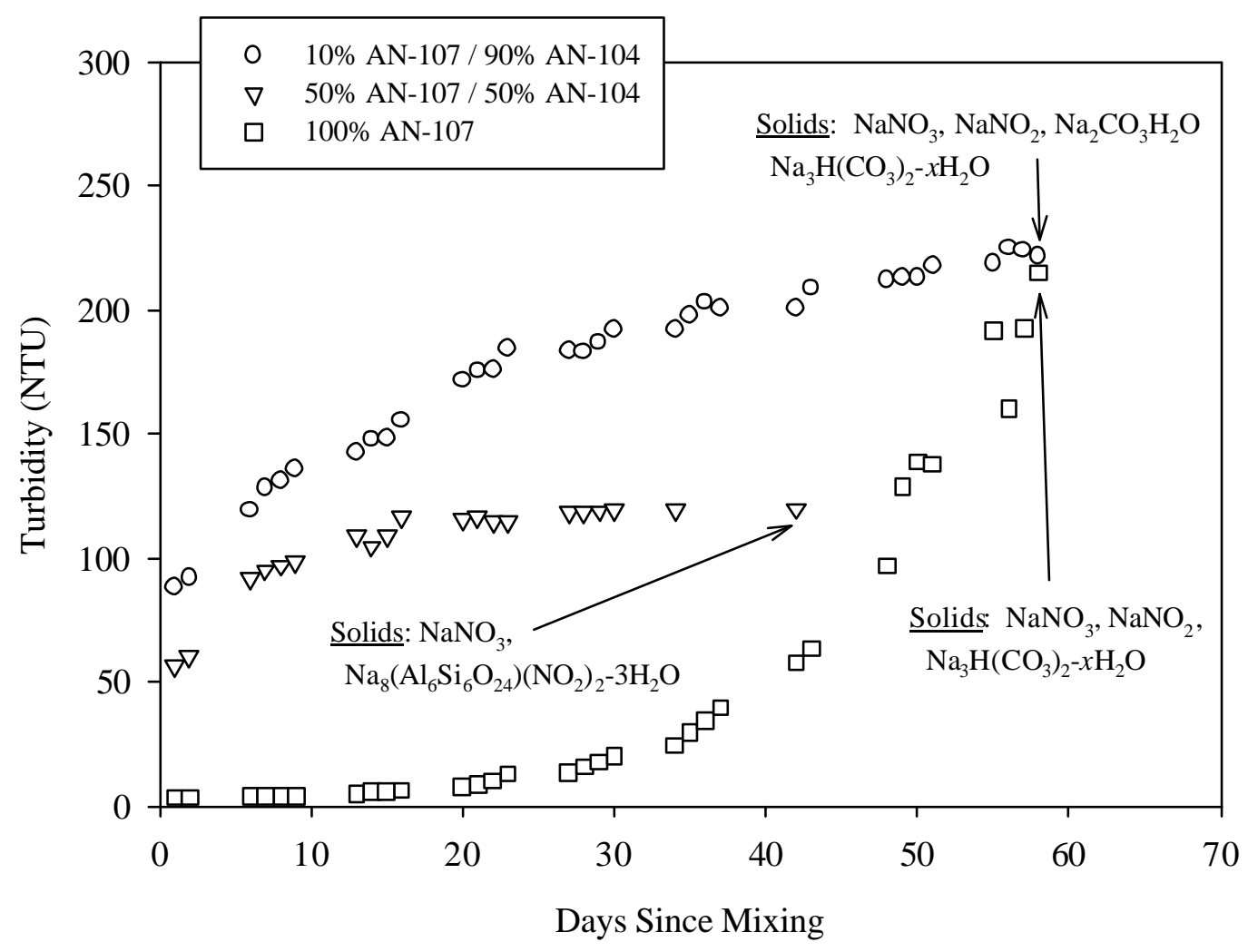

Figure 9. Turbidity and solid phases based on XRD and SEM in Mixtures of AN-107 and $\mathrm{AN}-104$. 


\subsubsection{Dilute Envelope Mixing Experiment}

These tests were added because no turbidity was visually observed (no turbidity meter was used) when active feed samples were mixed, contrary to the results from the simulant mixing study. This inconsistency was believed to be due to differences in feed concentrations; the simulants were more concentrated than the active feed samples. Mixing tests were conducted with simulants that were diluted to the same sodium molar concentrations as the corresponding active feed samples, as described in Table 14 and Table 15. The dilute feed solutions were combined in the same ratios as were used in the active mixing study, i.e., 3/30 on a volume basis.

Table 14. Active and Simulant Feed Sodium Concentrations.

\begin{tabular}{|c|c|c|}
\hline Active Feed & Envelope & $\begin{array}{c}\text { Measured Na } \\
\text { Concentration (M) }\end{array}$ \\
\hline AN-103 & A & 5.25 \\
\hline AZ-102 & B & 3.16 \\
\hline AN-102 & C & 5.98 \\
\hline Simulant Feed & Envelope & $\begin{array}{c}\text { Measured Na } \\
\text { Concentration (M) }\end{array}$ \\
\hline AN-107 ${ }^{\text {a }}$ & C & 8.2 \\
\hline AN-104 ${ }^{\text {a }}$ & A & 7.3 \\
\hline AW-101 & A & 6 \\
\hline AZ-102 & B & 4.7 \\
\hline AZ-101 & B & \\
\hline \multicolumn{2}{|c|}{} \\
a Simulant feeds used in Dilute Envelope Mixing study. Simulants were diluted with \\
water to have similar Na concentrations to corresponding active feed. \\
\hline
\end{tabular}

Table 15. Simulant Dilutions for Dilute Envelope Mixing Study.

\begin{tabular}{|l|c|c|c|}
\hline Simulant & Envelope & $\begin{array}{c}\text { Final Na } \\
\text { Concentration (M) }\end{array}$ & $\begin{array}{c}\text { \% of Original Simulant } \\
\text { Feed Solution }\end{array}$ \\
\hline Dilute AN-107 & C & 5.98 & 73 \\
\hline Dilute AN-104 & A & 5.25 & 72 \\
\hline Dilute AW-101 & A & 5.25 & 88 \\
\hline Dilute AZ-102 & B & 2.65 & 100 \\
\hline
\end{tabular}


Table 16. Chemical Composition of Selected Filtrates from Dilute Envelope Mixing Study: ICP-ES (mg/L).

\begin{tabular}{|c|c|c|c|}
\hline $\begin{array}{c}\text { Solution } \\
\text { Description }\end{array}$ & $\begin{array}{l}\text { 9\% dil. AN-107 } \\
91 \% \text { dil. AN-104 }\end{array}$ & $\begin{array}{l}9 \% \text { dil. AN-107 } \\
91 \% \text { dil. AW-101 }\end{array}$ & $\begin{array}{l}9 \% \text { dil. AN-107 } \\
91 \% \text { dil. } \mathrm{AZ}-102\end{array}$ \\
\hline $\mathrm{Al}$ & 9970 & 8860 & 232 \\
\hline $\mathrm{B}$ & 20 & 2.7 & 7.8 \\
\hline $\mathrm{Ba}$ & 0.027 & $<0.012$ & 0.06 \\
\hline $\mathrm{Ca}$ & 8.6 & 8.0 & 12.0 \\
\hline $\mathrm{Cd}$ & $<0.014$ & $<0.014$ & 0.028 \\
\hline $\mathrm{Co}$ & $<0.044$ & $<0.044$ & $<0.044$ \\
\hline $\mathrm{Cr}$ & 128 & 43.0 & 812 \\
\hline $\mathrm{Cu}$ & 1.7 & 1.7 & 2.1 \\
\hline $\mathrm{Fe}$ & 22.6 & 24 & 67 \\
\hline $\mathrm{La}$ & 1.2 & 1.4 & 1.9 \\
\hline$\overline{\mathrm{Li}}$ & $<0.1$ & $<0.1$ & $<0.1$ \\
\hline $\mathrm{Mg}$ & $<0.084$ & $<0.084$ & 0.10 \\
\hline $\mathrm{Mn}$ & 2.1 & 2.0 & 11.8 \\
\hline Mo & 30 & 2.3 & 56 \\
\hline $\mathrm{Na}$ & 111343 & 116980 & 69381 \\
\hline $\mathrm{Ni}$ & 34 & 34 & 44 \\
\hline $\bar{P}$ & 272 & 278 & 180 \\
\hline $\mathrm{Pb}$ & 27 & 50 & 23.7 \\
\hline $\mathrm{Si}$ & 91 & 79 & 104 \\
\hline $\mathrm{Sn}$ & $<0.26$ & $<0.26$ & $<0.26$ \\
\hline $\mathrm{Sr}$ & 0.07 & 0.10 & 0.10 \\
\hline $\mathrm{Ti}$ & $<0.14$ & $<0.14$ & $<0.14$ \\
\hline $\mathrm{V}$ & $<0.13$ & $<0.13$ & $<0.13$ \\
\hline $\mathrm{Zn}$ & 4.7 & 14 & 2.8 \\
\hline $\mathrm{Zr}$ & 2.0 & 2.3 & 2.3 \\
\hline$S$ & 1573 & 650 & 5280 \\
\hline
\end{tabular}


Table 17. Chemical Composition of Selected Filtrates from Dilute Envelope Mixing Study: Other Methods (mg/L).

\begin{tabular}{|c|c|c|c|c|}
\hline & $\begin{array}{c}\text { Analytical } \\
\text { Method }\end{array}$ & $\begin{array}{c}\text { 9\% dilAN-107 } \\
\mathbf{9 1 \%} \text { dilAN-104 }\end{array}$ & $\begin{array}{c}\text { 9\% dilAN-107 } \\
\mathbf{9 1 \%} \text { dilAW-101 }\end{array}$ & $\begin{array}{c}\text { 9\%dilAN-107 } \\
\mathbf{9 1 \%} \text { dilAZ-102 }\end{array}$ \\
\hline Chloride & IC & 4061 & 3530 & 1825 \\
\hline Fluoride & IC & 193 & 245 & 1054 \\
\hline Nitrate & IC & 79490 & 110019 & 34595 \\
\hline Nitrite & IEC/IPC & 39989 & 48185 & 34200 \\
\hline Phosphate & IC & 844 & 867 & 776 \\
\hline Sulfate & IC & 5590 & 1921 & 16166 \\
\hline K & AA & 2405 & 15881 & 3033 \\
\hline $\begin{array}{c}\text { Free OH } \\
\text { (molarity) }\end{array}$ & Titration & 0.8612 & 1.1706 & 0.0714 \\
\hline Organic C & TIC/TOC & 1009 & 2448 & 2256 \\
\hline Inorganic C & TIC/TOC & 23180 & 23480 & 15340 \\
\hline Formate & IC & 945 & 898 & 902 \\
\hline Oxalate & IC & 153 & 33 & 2641 \\
\hline Citrate & IEC & NBLR & NBLR & NBLR \\
\hline Glycolate & IEC & 1290 & 1222 & 1269 \\
\hline Formate & IEC & 916 & 968 & 743 \\
\hline Acetate & IEC & NBLR & NBLR & 507 \\
\hline HEDTA & IPC & 665 & 692 & 757 \\
\hline EDTA & IPC & 185 & 158 & $<100$ \\
\hline
\end{tabular}




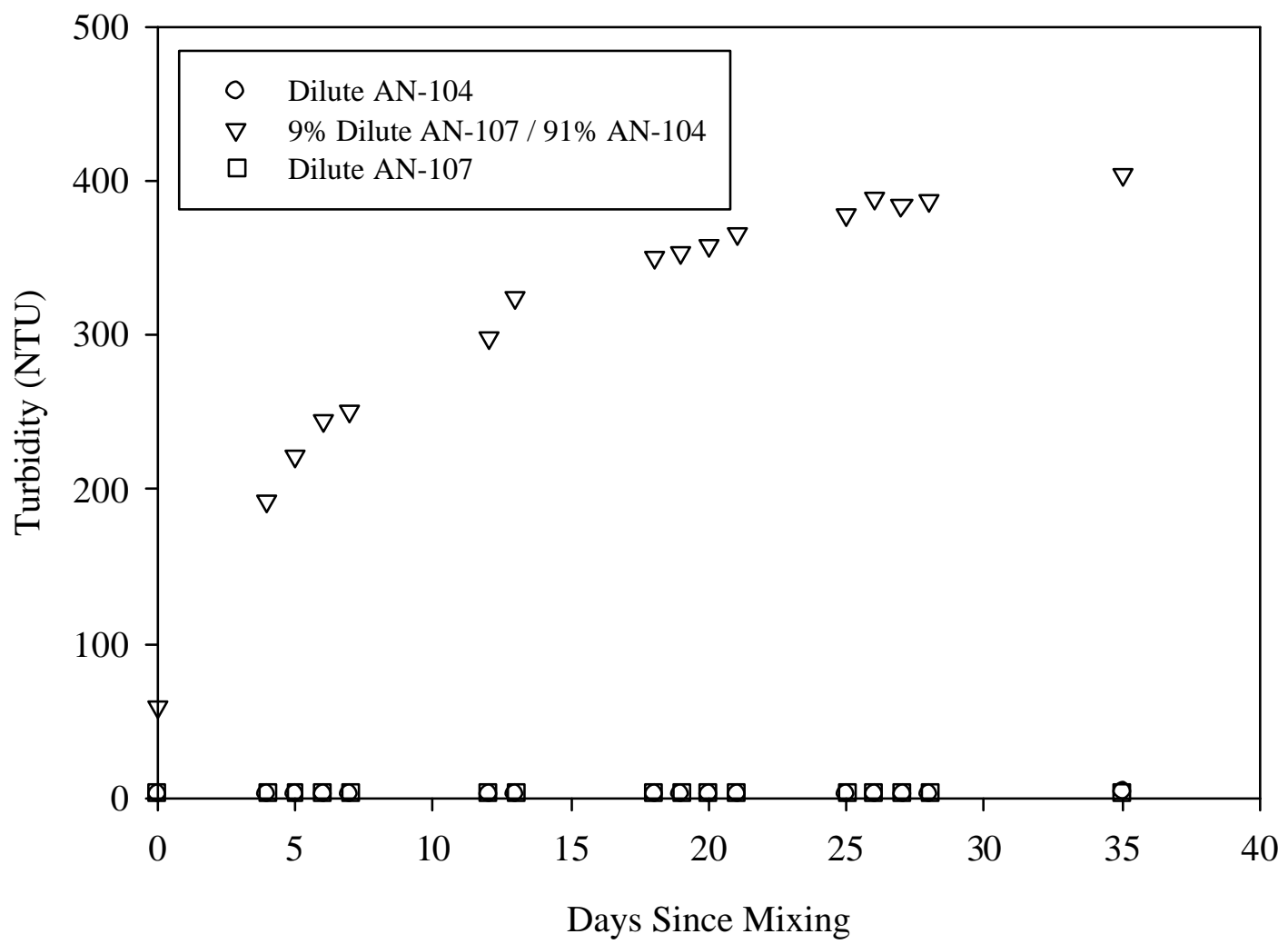

Figure 10. Turbidity in Dilute AN-107, Dilute AN-104, and a 9\% AN-107 \& 91\% AN104 Mixture. 


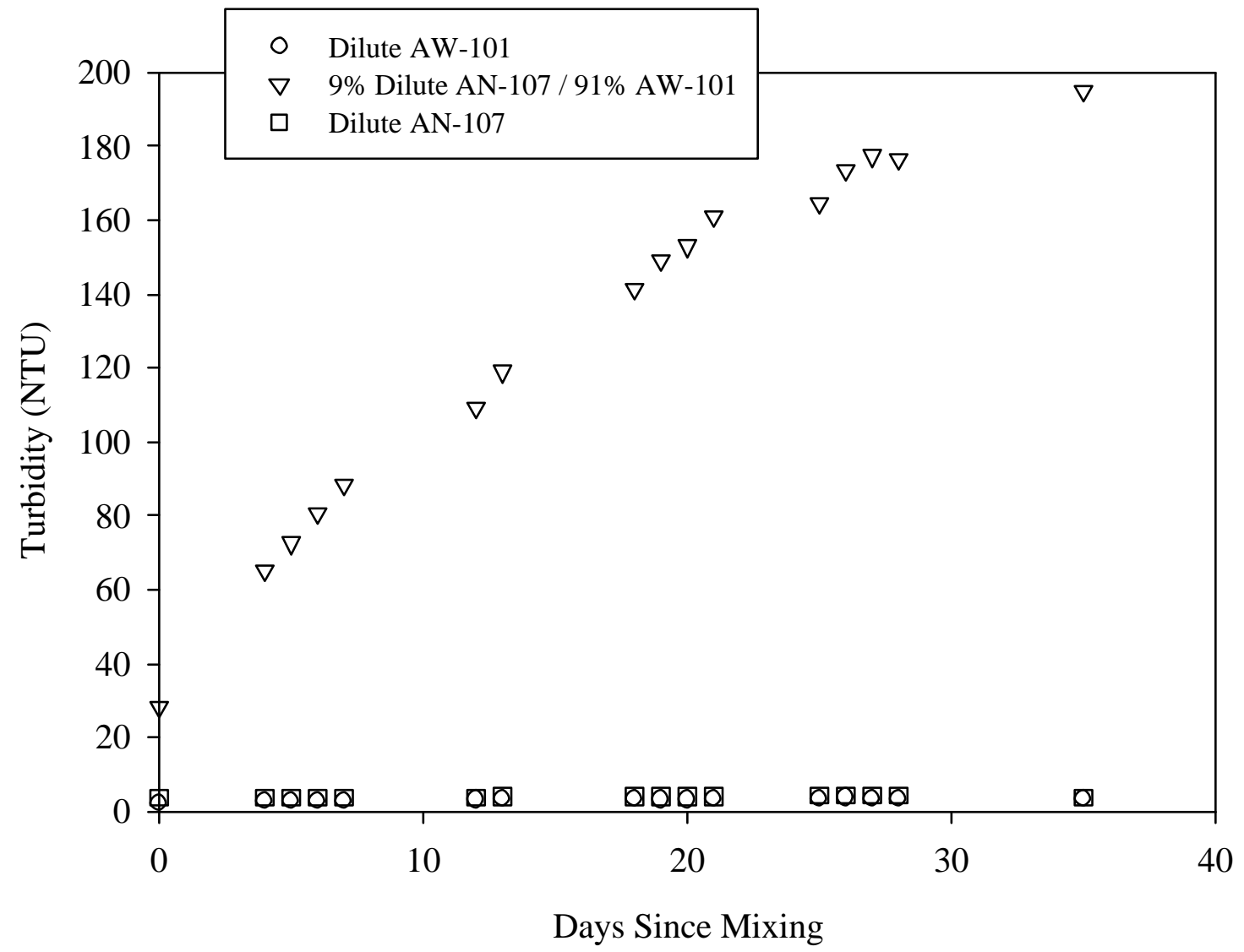

Figure 11. Turbidity in Dilute AN-107, Dilute AW-101, and a 9\% AN-107 \& 91\% AW101 Mixture. 


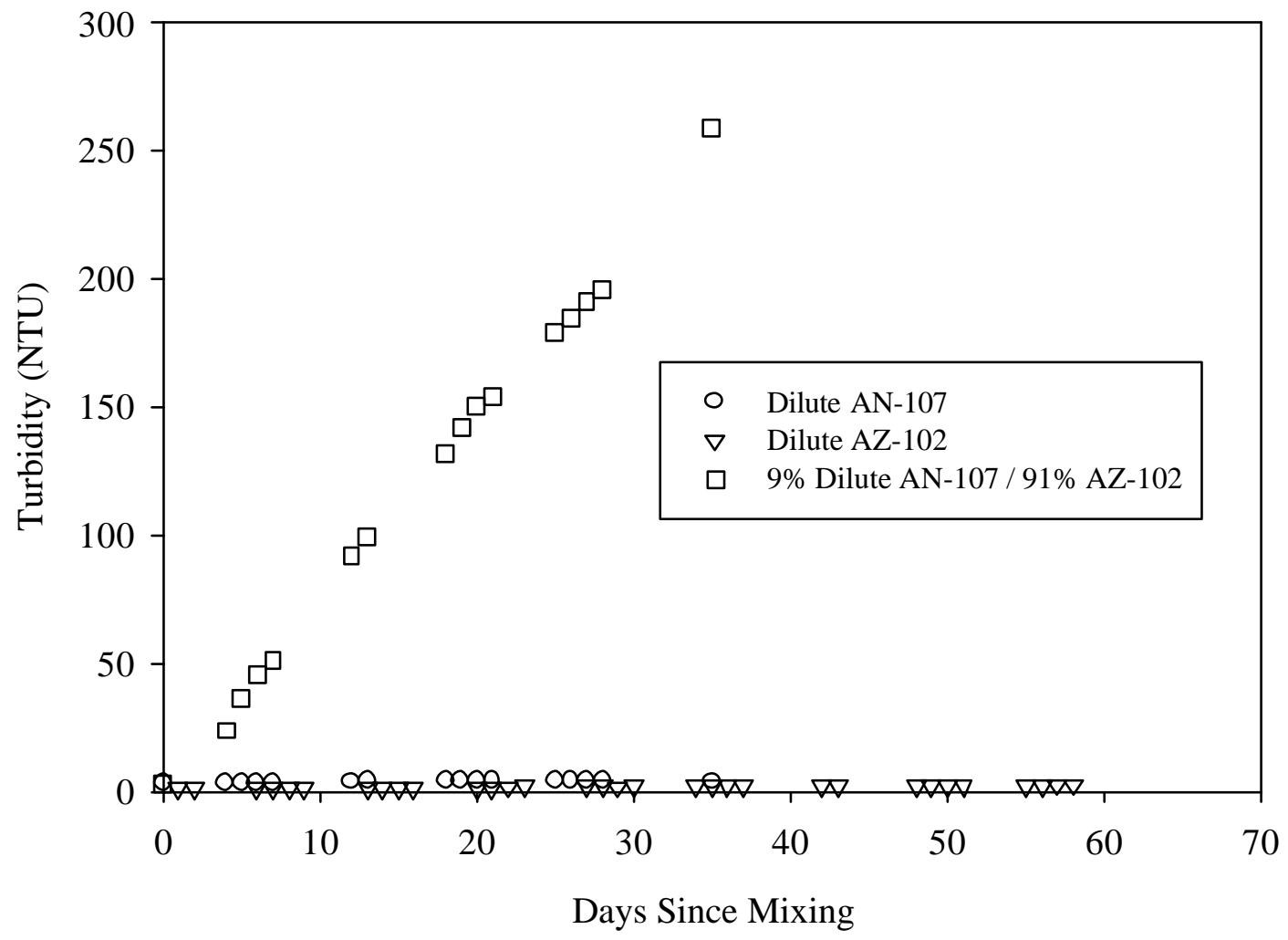

Figure 12. Mixture of Dilute AN-107 and Dilute AZ-102. 
WSRC-TR-2000-00319

SRT-RPP-2000-00020

Revision 0

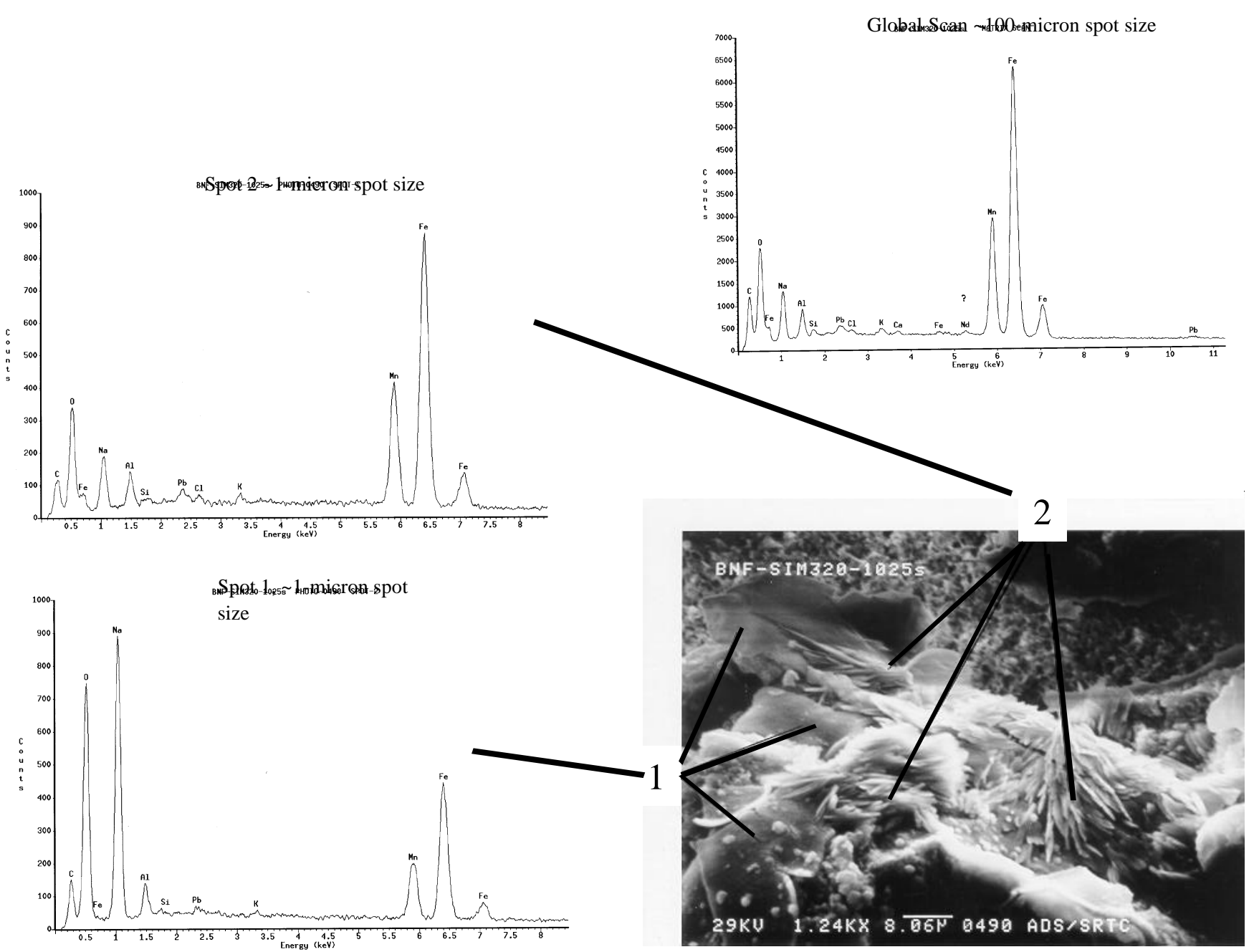

Figure 13. SEM image and corresponding EDX spectra of 9\% dilute AN-107 / 91\% dilute AN-104. Spot 1 is an EDX spectrum taken of large amorphous particles. Spot 2 is an EDX spectrum taken of crystalline particles. A third EDX spectrum is presented of a large spot size, which provides an average elemental composition of several particles. 


\subsection{Hydroxide-Concentration Experiment}

The reader is directed to Kaplan et al. (2000; SRT-RPP-2000-00016) for discussion, details and conclusions concerning this experiment. The analytical results presented in this section are for general information and the final report (Kaplan et al. 2000) should be consulted before using or trying to interpret these results.

The hydroxide-concentration experiment varied the concentration of hydroxide from $\mathrm{pH}$ 10 to $\mathrm{pH} 14.5$, or over a range of 4.5 orders of magnitude. The experimental design is described in detail in Section 3.4 and in Table 1. The individual test solutions were placed in $250 \mathrm{~mL}$ polypropylene bottles and were agitated on an Innova 2300 platform shaker at 80 revolutions per minute. The experiment was run under ambient laboratory temperature. The mean temperature during the monitoring period was $20.8 \pm 0.1^{\circ} \mathrm{C}$. The detailed temperature data for this study is presented in Appendix A. The $\mathrm{pH}$ was adjusted with either concentration $\mathrm{HNO}_{3}$ or $\mathrm{NaOH}$.

\subsubsection{Titration Basis for $\mathrm{pH}$ Adjustment}

Table 18. Titration Results for Simulants.

\begin{tabular}{|l|c|c|c|c|c|c|c|}
\hline & $\begin{array}{c}\text { Sample } \\
\text { Vol. }\end{array}$ & Sample 1 & Sample 1 & Sample 2 & Sample 2 & Average & Used \\
\hline Feed & $\mathbf{m L}$ & $\begin{array}{c}\text { mL 0.1181 } \\
\text { M HCl }\end{array}$ & Moles/L & $\begin{array}{c}\text { mL 0.1181 } \\
\text { M HCl }\end{array}$ & Moles/L & Moles/L & Moles/L \\
\hline AN-107 & 2 & 5.95 & 0.351 & 6.07 & 0.358 & 0.355 & 0.357 \\
\hline AW-101 & 0.2 & 3.41 & 2.014 & 3.35 & 1.978 & 1.996 & 2.007 \\
\hline AN-104 & 0.2 & 2.835 & 1.674 & 2.77 & 1.636 & 1.655 & 1.665 \\
\hline AZ-101 & 2 & 7.175 & 0.424 & 7.04 & 0.416 & 0.420 & 0.42 \\
\hline AZ-102 & 2 & 5.09 & 0.301 & 4.985 & 0.294 & 0.297 & 0.297 \\
\hline C-106 Leachate & 0.2 & 4.175 & 2.465 & 4.16 & 2.456 & 2.461 & \\
\hline AZ-102 Leachate & 0.2 & 2.68 & 1.583 & 2.585 & 1.526 & 1.554 & \\
\hline${ }^{2}$ Sample volume diluted to 60-mL with water. \\
\hline \multicolumn{7}{|l|}{} \\
\hline
\end{tabular}




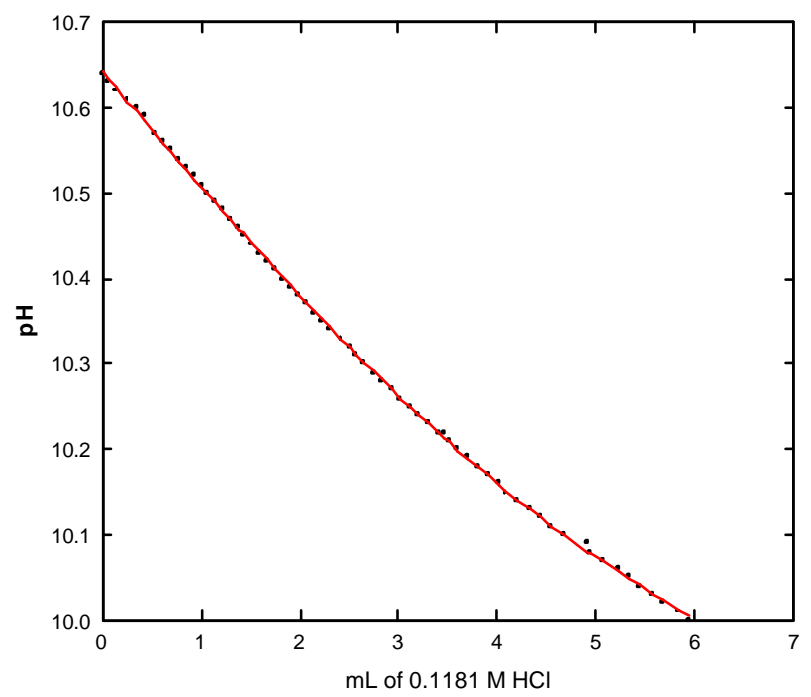

Figure 14. Titration Curve for AN-107.

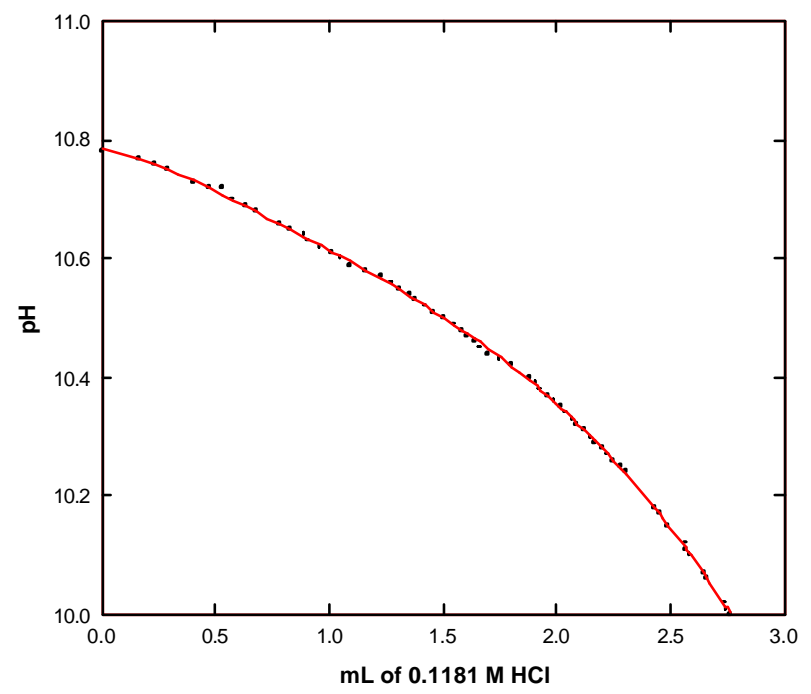

Figure 15. Titration Curve for AN-104. 


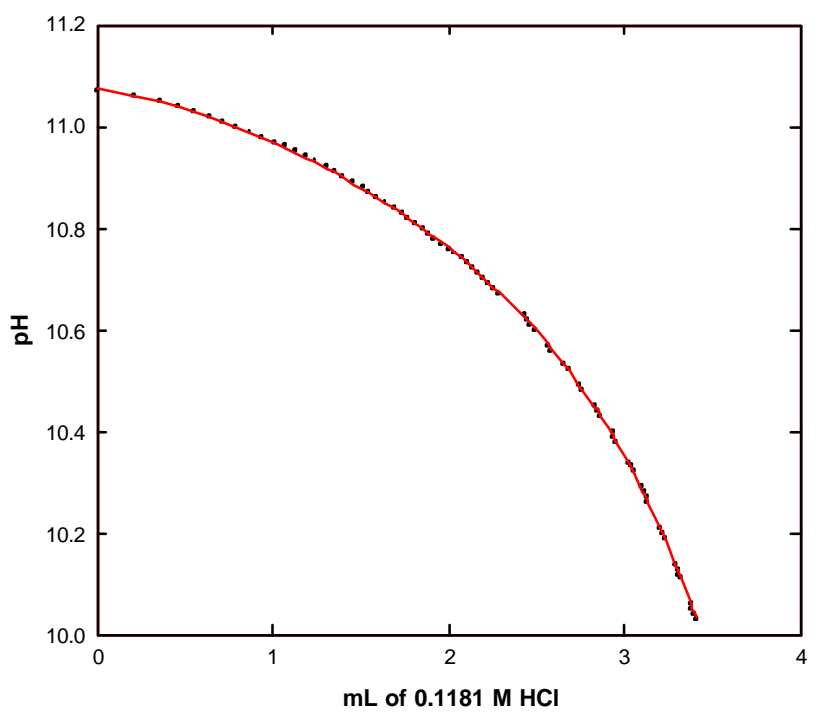

Figure 16. Titration Curve for AW-101.

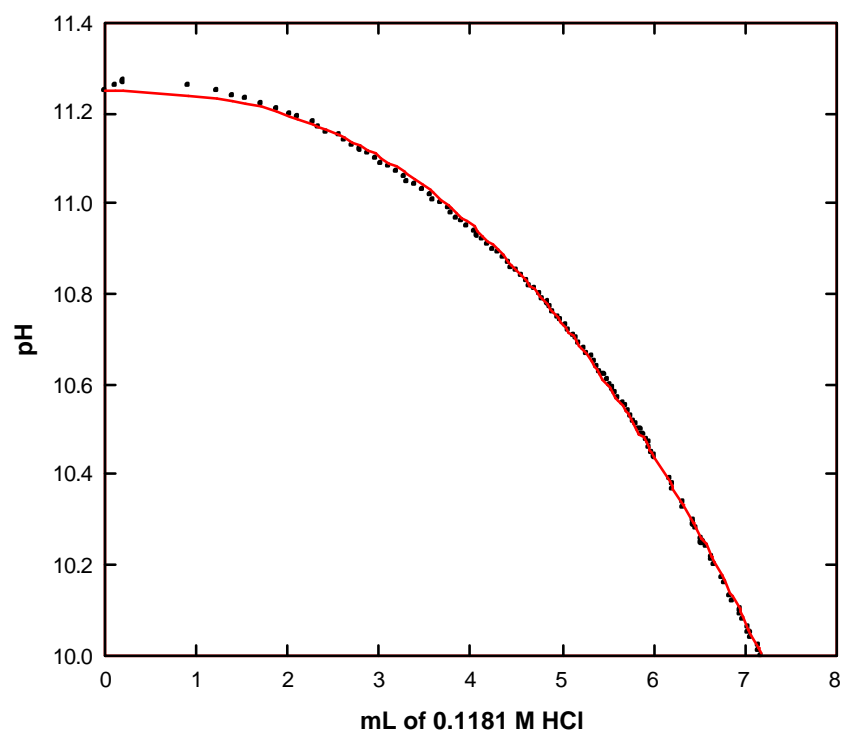

Figure 17. Titration Curve for AZ-101. 


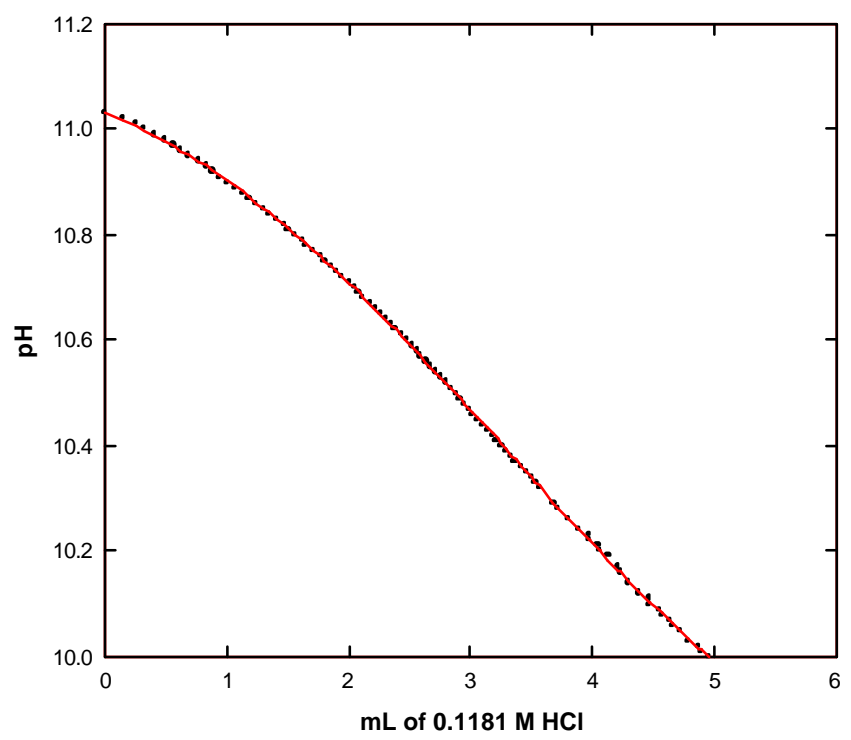

Figure 18. Titration Curve for AZ-102.

Table 19. Based on Preliminary Titration Experiments, Amount of Nitric Acid (70 \%) or Sodium Hydroxide (50 wt-\%) Required to Adjust $\mathrm{pH}$ of Simulants.

\begin{tabular}{|c|c|c|c|c|c|}
\hline Feed & $\begin{array}{c}\text { Base } \\
\text { Equivalents }\end{array}$ & $\begin{array}{c}\mathbf{H N O}_{3} \\
\text { Added for } \\
\text { pH 10 }\end{array}$ & $\begin{array}{c}\mathbf{H N O}_{3} \\
\text { Added for } \\
\text { pH 11 }\end{array}$ & $\begin{array}{c}\mathbf{H N O}_{3} \\
\text { Added for } \\
\mathbf{p H ~ 1 3}\end{array}$ & $\begin{array}{c}\text { NaOH Added } \\
\text { for pH 14.5 }\end{array}$ \\
\hline & (Mol/L) & $\mathbf{\text { Mol/L) }}$ & $\mathbf{( M o l / L )}$ & $\mathbf{( M o l} / \mathrm{L})$ & (Mol/L) \\
\hline $\mathrm{AN}-107$ & 0.357 & 0.357 & 0.33915 & & 3.16 \\
\hline $\mathrm{AN}-104$ & 1.665 & 1.665 & 1.58175 & 1.5 & 1.495 \\
\hline $\mathrm{AW}-101$ & 2.007 & 2.007 & 1.90665 & 1.8 & 1.153 \\
\hline $\mathrm{AZ}-101$ & 0.42 & 0.42 & 0.399 & 0.32 & 2.74 \\
\hline $\mathrm{AZ}-102$ & 0.297 & 0.297 & 0.28215 & 0.197 & 2.863 \\
\hline
\end{tabular}

(a) Added 0.1 moles of $\mathrm{NaOH}$ instead of Nitric Acid since AN-107 should be less than pH 13.

\subsection{2. $\quad$ pH Adjustment of AN-107 Simulant}

The addition of nitric acid to the AN-107 feed was observed to produce bubbles and a brown gas. The gas is assumed to be $\mathrm{NO}_{\mathrm{x}}$ formed from the nitrite anion due to highlocalized acid concentrations. More effective mixing might mitigate this gas evolution. 
Immediate formation of solids was not observed. Addition of $\mathrm{NaOH}$ did not produce any observable gas.

Figure 19 displays the result of monitoring turbidity for the $\mathrm{pH}$ adjusted AN-107 simulant. Immediate formation of white solids was observed in the targeted $\mathrm{pH} 10$ and 11 bottles. $^{2}$ These solids may have redissolved since significant turbidity was not observed until the seventh day after adjustment. As indicated in Figure 19, the pH 14.5 (high hydroxide) test had formed solids by day 5 . These solids were clearly different from the low hydroxide solids and tended to be thick and gelatinous. The gelatinous solids were difficult to sample and tended to plug the pipette tip. Figure 20 is a photograph of the test solutions and clearly shows the solids at the bottom of the $\mathrm{pH} 10$ and 11 tests. The gelatinous solids in the $\mathrm{pH} 14.5$ test are barely visible in Figure 20 as a darker layer in the bottom third of the solution.

After completion of the turbidity monitoring, the test solutions were passed through a $0.45-\mu \mathrm{m}$ nylon filter and the supernate chemically characterized (Table 20). As expected, the free hydroxide value for the $\mathrm{pH} 10$ and 11 tests is below detection limit, whereas the $\mathrm{pH} 13$ value is near $0.1-\mathrm{M}$ and the $\mathrm{pH} 14.5$ value is $>2-\mathrm{M}$. The only component concentrations that declined in the acid adjusted tests was $\mathrm{Ca}$ and possibly $\mathrm{Al}(\mathrm{OH})_{4}{ }^{-}$. However, Al by ICP-ES remained constant. The declines in concentration observed for the hydroxide-added test were $\mathrm{Fe}, \mathrm{Mn}$, and possibly $\mathrm{Ni}$ and $\mathrm{PO}_{4}{ }^{3-}$. The amount of nitrite consumed during acid addition, presumably as $\mathrm{NO}_{\mathrm{x}}$, was too small to be detected by chemical analysis.

2 Final $\mathrm{pH}$ levels of the $\mathrm{pH}$-adjusted solutions were not measured because of the analytical problem associated with making this measurement in high ionic strength solutions. Throughout this report, we refer to the various treatments by their targeted $\mathrm{pH}$ levels, e.g., $\mathrm{pH} 10,11,13$, and 14.5. 
Table 20. Composition of pH-Adjusted AN-107 Simulant.

\begin{tabular}{|c|c|c|c|c|c|c|c|}
\hline Tank & & Feed & pH 10 & pH 11 & pH 13 & pH 14.5 & Analysis \\
\hline Components & Units & Found & Found & Found & Found & Found & Method \\
\hline $\mathrm{Ag}$ & $\mathrm{mg} / \mathrm{L}$ & $<0.3$ & $\mathrm{NA}^{\mathrm{a}}$ & NA & $\mathrm{NA}$ & NA & ICP-ES \\
\hline $\mathrm{Al}$ & $\mathrm{mg} / \mathrm{L}$ & 194 & 195 & 197 & 198 & 199 & ICP-ES \\
\hline $\mathrm{B}$ & $\mathrm{mg} / \mathrm{L}$ & 38 & 39 & 39 & 39 & 35 & ICP-ES \\
\hline $\mathrm{Ba}$ & $\mathrm{mg} / \mathrm{L}$ & 0.17 & 0.24 & 0.26 & 0.24 & 0.47 & ICP-ES \\
\hline $\mathrm{Ca}$ & $\mathrm{mg} / \mathrm{L}$ & 138 & 94 & 95 & 140 & 129 & ICP-ES \\
\hline $\mathrm{Cd}$ & $\mathrm{mg} / \mathrm{L}$ & $<0.02$ & $<0.014$ & $<0.014$ & $<0.014$ & $<0.014$ & ICP-ES \\
\hline $\mathrm{Ce}$ & $\mathrm{mg} / \mathrm{L}$ & 50.2 & NA & NA & NA & NA & ICP-ES \\
\hline Co & $\mathrm{mg} / \mathrm{L}$ & 0.39 & $<0.044$ & $<0.044$ & $<0.044$ & $<0.044$ & ICP-ES \\
\hline $\mathrm{Cr}$ & $\mathrm{mg} / \mathrm{L}$ & 148 & 157 & 158 & 158 & 134 & ICP-ES \\
\hline Cs & $\mathrm{mg} / \mathrm{L}$ & 22.3 & NA & NA & NA & NA & ICP-ES \\
\hline $\mathrm{Cu}$ & $\mathrm{mg} / \mathrm{L}$ & 32 & 33 & 33 & 33 & 29 & ICP-ES \\
\hline $\mathrm{Fe}$ & $\mathrm{mg} / \mathrm{L}$ & 1623 & 1721 & 1720 & 1740 & 1210 & ICP-ES \\
\hline $\mathrm{K}$ & $\mathrm{mg} / \mathrm{L}$ & 1921 & 2021 & 1984 & 1995 & 1810 & AA \\
\hline $\mathrm{La}$ & $\mathrm{mg} / \mathrm{L}$ & 40 & 42 & 42 & 43 & 34 & ICP-ES \\
\hline $\mathrm{Mg}$ & $\mathrm{mg} / \mathrm{L}$ & 20 & 19 & 20 & 20 & 2 & ICP-ES \\
\hline $\mathrm{Mn}$ & $\mathrm{mg} / \mathrm{L}$ & 564 & 585 & 585 & 592 & 304 & ICP-ES \\
\hline Mo & $\mathrm{mg} / \mathrm{L}$ & 36 & 38 & 38 & 38 & 35 & ICP-ES \\
\hline $\mathrm{Na}$ & $\mathrm{mg} / \mathrm{L}$ & 188170 & 192899 & 200922 & 195174 & 222725 & ICP-ES \\
\hline $\mathrm{Na}$ & $\mathrm{mg} / \mathrm{L}$ & 201400 & NM & NM & NM & NM & $\mathrm{AA}$ \\
\hline $\mathrm{Nd}$ & $\mathrm{mg} / \mathrm{L}$ & 84.4 & NA & NA & NA & NA & ICP-ES \\
\hline $\mathrm{Ni}$ & $\mathrm{mg} / \mathrm{L}$ & 501 & 536 & 539 & 535 & 483 & ICP-ES \\
\hline $\mathrm{P}$ & $\mathrm{mg} / \mathrm{L}$ & 420 & 416 & 420 & 425 & 379 & ICP-ES \\
\hline $\mathrm{Pb}$ & $\mathrm{mg} / \mathrm{L}$ & 364 & 402 & 407 & 402 & 322 & ICP-ES \\
\hline $\mathrm{Si}$ & $\mathrm{mg} / \mathrm{L}$ & 1.4 & 1.5 & 1.5 & 1.7 & 6.8 & ICP-ES \\
\hline $\mathrm{Sn}$ & $\mathrm{mg} / \mathrm{L}$ & $<0.26$ & $<0.26$ & $<0.26$ & $<0.26$ & $<0.26$ & ICP-ES \\
\hline $\mathrm{Sr}$ & $\mathrm{mg} / \mathrm{L}$ & 1.3 & 1.1 & 1.1 & 1.3 & 1.08 & ICP-ES \\
\hline $\mathrm{Ti}$ & $\mathrm{mg} / \mathrm{L}$ & $<0.14$ & $<0.14$ & $<0.14$ & $<0.14$ & $<0.14$ & ICP-ES \\
\hline $\mathrm{Zn}$ & $\mathrm{mg} / \mathrm{L}$ & 44 & 46 & 46 & 46 & 41 & ICP-ES \\
\hline Chloride & $\mathrm{mg} / \mathrm{L}$ & 1330 & 2530 & 2602 & 2598 & 2434 & IC \\
\hline Fluoride & $\mathrm{mg} / \mathrm{L}$ & 3430 & 3496 & 3461 & 3493 & 3079 & IC \\
\hline Formate & $\mathrm{mg} / \mathrm{L}$ & 11232 & 11972 & 11959 & 11727 & 10997 & IC \\
\hline Nitrate & $\mathrm{mg} / \mathrm{L}$ & 213930 & 254914 & 251910 & 230079 & 202838 & IC \\
\hline Nitrite & $\mathrm{mg} / \mathrm{L}$ & 57090 & 58290 & 58497 & 59969 & 54777 & IC \\
\hline Oxalate & $\mathrm{mg} / \mathrm{L}$ & 335 & 491 & 465 & 483 & 459 & IC \\
\hline Phosphate & $\mathrm{mg} / \mathrm{L}$ & 1500 & 1899 & 1581 & 1587 & 1291 & IC \\
\hline Sulfate & $\mathrm{mg} / \mathrm{L}$ & 7280 & 8572 & 8355 & 8418 & 7113 & $\mathrm{IC}$ \\
\hline TIC & $\mathrm{mg} / \mathrm{L}$ & 16100 & 19806 & 19180 & 21320 & 22740 & $\mathrm{CO}_{2}$ Evolution \\
\hline TOC & $\mathrm{mg} / \mathrm{L}$ & 15800 & 20320 & 22340 & 24800 & 33300 & $\mathrm{CO}_{2}$ Evolution \\
\hline Carbonate(TIC) & $\mathrm{mg} / \mathrm{L}$ & 80439 & 98940 & 95810 & 106500 & 113600 & Calc. from TIC \\
\hline Aluminate & Molar & 0.054 & 0.0295 & $<0.002$ & 0.022 & 0.0933 & Titration \\
\hline Carbonate & Molar & 1.052 & NM & NM & NM & NM & Titration \\
\hline Free $\mathrm{OH}$ & Molar & 0.039 & $<0.02$ & $<0.02$ & 0.064 & 2.19 & Titration \\
\hline
\end{tabular}




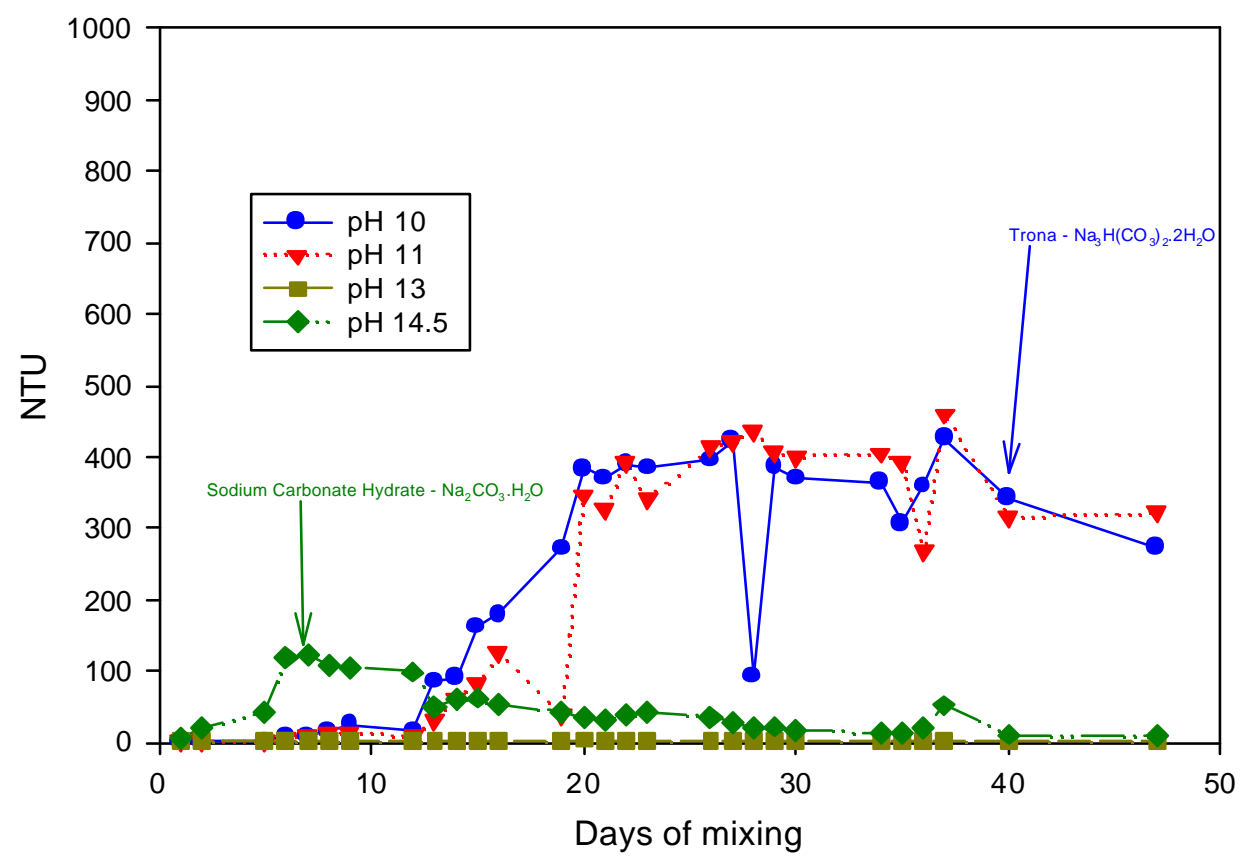

Figure 19. Turbidity of pH-Adjusted AN-107 Simulant.

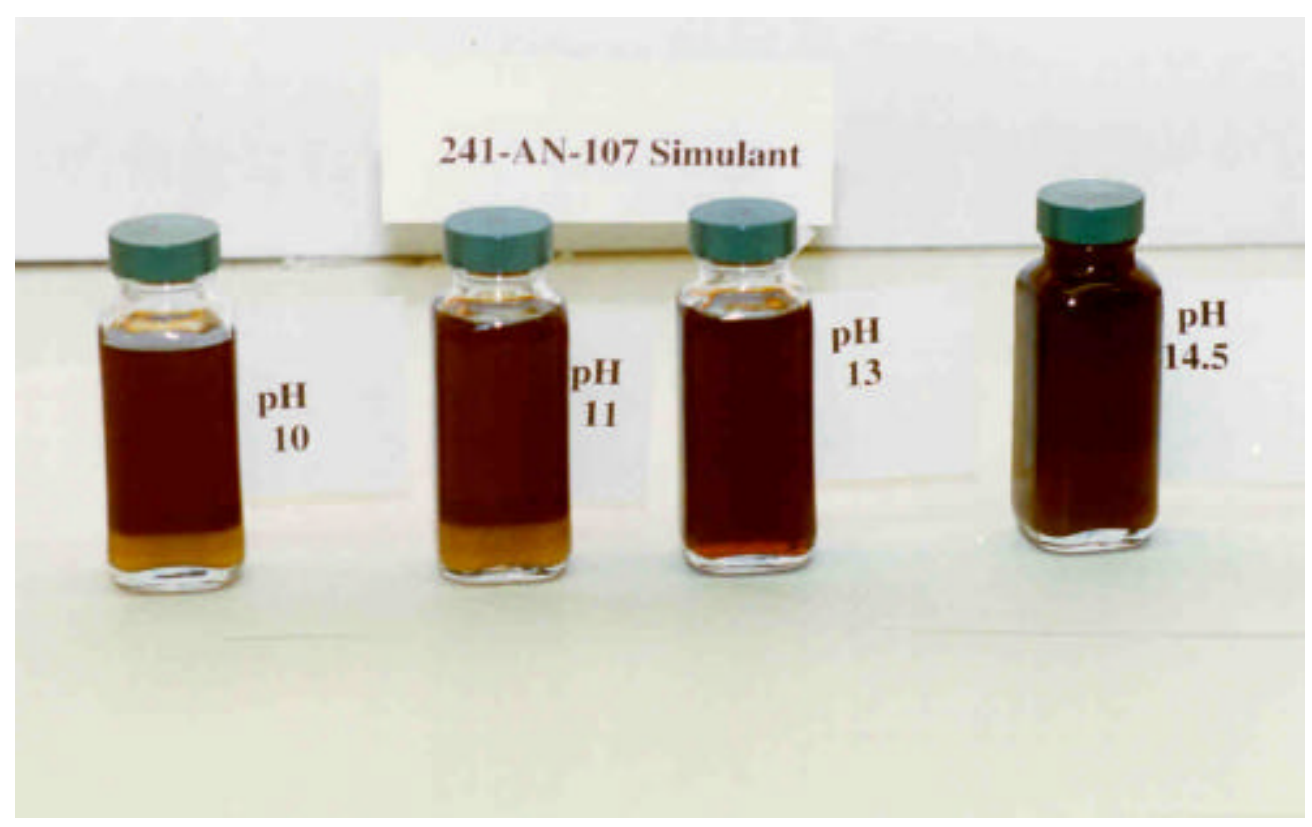

Figure 20. AN-107 pH-Adjusted Simulant. 
The dried solids from two of the tests, $\mathrm{pH} 10$ and $\mathrm{pH}$ 14.5, were submitted for $\mathrm{x}$-ray diffraction analysis (XRD) to identify the solids present. The XRD scan for the acidadjusted pH 10 test detected the following compounds (see appendix B Figure B13):

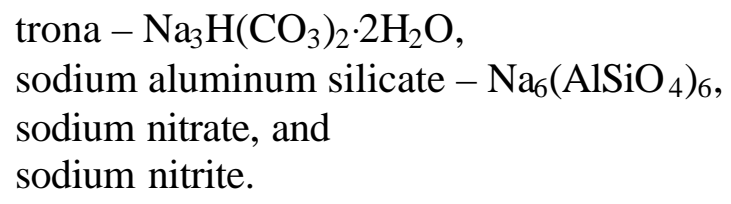

Since the solids were not washed, the sodium nitrate and sodium nitrite salts could be due to the residual supernate, which dried on the solids. The XRD scan for the base-adjusted pH 14.5 test detected the following compounds (see Appendix B Figure B14):

sodium carbonate hydrate $-\mathrm{Na}_{2} \mathrm{CO}_{3} \cdot \mathrm{H}_{2} \mathrm{O}$,

sodium nitrate, and

sodium nitrite.

Since the solids were not washed, the sodium nitrate and sodium nitrite salts could be due to the residual supernate, which dried on the solids. Since XRD is dominated by the bulk solids, the lack of identification of $\mathrm{Ca}, \mathrm{Fe}, \mathrm{Mn}$ or $\mathrm{PO}_{4}{ }^{3-}$ species is understandable.

While the addition of only small amounts of hydroxide did not produce solids ( $\mathrm{pH} 13$ test), the addition of acid or of molar quantities of hydroxide will produce solids. Table 21 summarizes the observations on $\mathrm{pH}$ adjusting $\mathrm{AN}-107$.

Table 21. Summary of pH Adjusted AN-107 Observations.

\begin{tabular}{|c|c|c|c|c|}
\hline & & & \multicolumn{2}{|c|}{ Observed } \\
\hline Targeted pH & $\begin{array}{c}\text { Targeted[OH] } \\
(\mathbf{M})\end{array}$ & $\begin{array}{c}\text { Measured }[\mathbf{O H}] \\
(\mathbf{M})\end{array}$ & Solids & Gas \\
\hline 10 & 0.0001 & $<0.01$ & Yes & Yes \\
\hline 11 & 0.001 & $<0.01$ & Yes & Yes \\
\hline 13 & 0.1 & 0.64 & No & No \\
\hline 14.5 & 3.16 & 2.2 & Yes & No \\
\hline
\end{tabular}




\subsection{3. pH Adjustment of AN-104 Simulant}

The addition of the nitric acid to the $\mathrm{AN}-104$ feed was observed to produce bubbles and a brown gas. The gas is assumed to be $\mathrm{NO}_{\mathrm{x}}$ formed from the nitrite anion due to highlocalized acid concentrations. More effective mixing might mitigate this gas evolution. Immediate formation of white solids was observed. Addition of sodium hydroxide did not produce any observable gas or solids.

Figure 21 displays the result of monitoring turbidity for the $\mathrm{pH}$ adjusted AN-104 simulant. The immediate formation of white solids was observed in the targeted $\mathrm{pH} 10$, 11, and 13 bottles (see footnote 2). These solids after the first few days were observed to settle quickly leading to erratic turbidity readings. This implies that the density and probably the crystallinity of the particles were increasing over time. As indicated in Figure 21, the $\mathrm{pH} 14.5$ (high hydroxide) test did not produce any solids. Figure 22 is a photograph of the test solutions and clearly shows the solids at the bottom of the $\mathrm{pH} 10$ and 11 tests. Only a small amount of solids was present in the $\mathrm{pH} 13$ test and is therefore not clearly visible in Figure 22.

After completion of the turbidity monitoring, the test solutions were filtered using vacuum filtration through a 0.45 -micron nylon filter and the supernate submitted for analysis. Table 22 gives the results of the analysis. The filtered solids from the $\mathrm{pH} 10$ experiment were submitted for XRD to identify the solids present. The XRD scan for the acid-adjusted $\mathrm{pH} 10$ test detected the following compounds (see Appendix B, Figure B15):

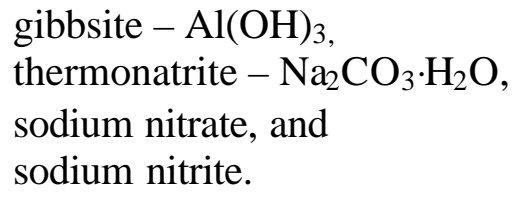

Since the solids were not washed, the sodium nitrate and sodium nitrite salts could be due to the residual supernate, which dried on the solids. The analysis of the supernate shown in Table 22 confirms the solids characterization since both $\mathrm{Al}$ by ICP-ES, $\mathrm{Al}(\mathrm{OH})_{4}{ }^{-}$by titration and TIC confirm drops in concentrations for the appropriate metal and anion. The only other components that declined in concentration in the acid adjusted tests were silicon, chloride and nitrite anions, and TOC. The apparent TOC decline may be a poor analysis since almost no organic carbon is in the AN-104 simulant. The decline in nitrite was probably due to the large amount of nitric acid required by the AN-104 simulant (Table 19) as evidenced by the $\mathrm{NO}_{\mathrm{x}}$ evolution observed during acid addition. Since XRD is dominated by the bulk solids, the lack of identification of $\mathrm{Si}$ or $\mathrm{Cl}$ species is understandable. 
The most interesting results shown in Table 22 are the free hydroxide results. Nominally, the $\mathrm{pH} 10,11$, and 13 tests should have had about $0.0001,0.001$ and 0.1 molar free hydroxide levels. Instead, the respective free hydroxide values were $0.83,0.81$ and 0.72 molar. Since the predominant product was the precipitation of gibbsite, $\mathrm{Al}(\mathrm{OH})_{3}$, the following reaction must have occurred:

$$
\mathrm{Al}(\mathrm{OH})_{4}{ }^{-} \longrightarrow \mathrm{Al}(\mathrm{OH})_{3}+\mathrm{OH}^{-}
$$

As gibbsite slowly precipitates due to the dissociation of the aluminate, free hydroxide is released. 
Table 22. Composition of pH-Adjusted AN-104 Simulant.

\begin{tabular}{|c|c|c|c|c|c|c|c|}
\hline $\begin{array}{c}\text { Tank } \\
\text { Components }\end{array}$ & Units & $\begin{array}{c}\text { Feed } \\
\text { Found }\end{array}$ & $\begin{array}{l}\text { pH 10 } \\
\text { Found }\end{array}$ & $\begin{array}{l}\text { pH } 11 \\
\text { Found }\end{array}$ & $\begin{array}{l}\text { pH } 13 \\
\text { Found }\end{array}$ & $\begin{array}{c}\text { pH } 14.5 \\
\text { Found }\end{array}$ & $\begin{array}{c}\text { Analysis } \\
\text { Method }\end{array}$ \\
\hline $\mathrm{Ag}$ & $\mathrm{mg} / \mathrm{L}$ & $<0.03$ & $\mathrm{NM}^{\mathrm{a}}$ & NM & NM & NM & ICP-ES \\
\hline $\mathrm{Al}$ & $\mathrm{mg} / \mathrm{L}$ & 16952 & 6920 & 7230 & 16700 & 17700 & ICP-ES \\
\hline $\mathrm{B}$ & $\mathrm{mg} / \mathrm{L}$ & 33 & 31 & 33 & 34 & 32 & ICP-ES \\
\hline $\mathrm{Ba}$ & $\mathrm{mg} / \mathrm{L}$ & 5.6 & $<0.04$ & 0.05 & 0.11 & 0.23 & ICP-ES \\
\hline $\mathrm{Ca}$ & $\mathrm{mg} / \mathrm{L}$ & 2.8 & $<0.04$ & 0.4 & 0.9 & 1.9 & ICP-ES \\
\hline $\mathrm{Cd}$ & $\mathrm{mg} / \mathrm{L}$ & $<0.02$ & $<0.014$ & $<0.014$ & $<0.014$ & $<0.014$ & ICP-ES \\
\hline $\mathrm{Ce}$ & $\mathrm{mg} / \mathrm{L}$ & $<0.7$ & NM & NM & NM & NM & ICP-ES \\
\hline $\mathrm{Co}$ & $\mathrm{mg} / \mathrm{L}$ & $<0.05$ & $<0.044$ & $<0.044$ & $<0.044$ & $<0.044$ & ICP-ES \\
\hline $\mathrm{Cr}$ & $\mathrm{mg} / \mathrm{L}$ & 204 & 174 & 179 & 179 & 201 & ICP-ES \\
\hline Cs & $\mathrm{mg} / \mathrm{L}$ & 0.7 & NM & NM & NM & NM & $\mathrm{AA}$ \\
\hline $\mathrm{Cu}$ & $\mathrm{mg} / \mathrm{L}$ & 0.14 & $<0.05$ & $<0.05$ & $<0.05$ & $<0.05$ & ICP-ES \\
\hline $\mathrm{Fe}$ & $\mathrm{mg} / \mathrm{L}$ & 0.31 & 0.38 & 0.14 & 0.23 & 0.76 & ICP-ES \\
\hline $\mathrm{K}$ & $\mathrm{mg} / \mathrm{L}$ & 4320 & 4055 & 4011 & 3941 & 4080 & $\mathrm{AA}$ \\
\hline $\mathrm{La}$ & $\mathrm{mg} / \mathrm{L}$ & $<0.06$ & $<0.06$ & $<0.06$ & $<0.06$ & $<0.06$ & ICP-ES \\
\hline $\mathrm{Li}$ & $\mathrm{mg} / \mathrm{L}$ & 0.26 & 0.12 & 0.11 & $<0.1$ & 0.12 & ICP-ES \\
\hline $\mathrm{Mg}$ & $\mathrm{mg} / \mathrm{L}$ & $<0.09$ & $<0.084$ & $<0.084$ & $<0.084$ & $<0.084$ & ICP-ES \\
\hline $\mathrm{Mn}$ & $\mathrm{mg} / \mathrm{L}$ & $<0.009$ & 0.024 & $<0.009$ & $<0.009$ & 0.07 & ICP-ES \\
\hline Mo & $\mathrm{mg} / \mathrm{L}$ & 49 & 48 & 51 & 48 & 48 & ICP-ES \\
\hline $\mathrm{Na}$ & $\mathrm{mg} / \mathrm{L}$ & 164670 & 160785 & 157559 & 153602 & 200607 & ICP-ES \\
\hline $\mathrm{Na}$ & $\mathrm{mg} / \mathrm{L}$ & 168200 & NM & NM & NM & NM & AA \\
\hline $\mathrm{Nd}$ & $\mathrm{mg} / \mathrm{L}$ & $<0.3$ & NM & NM & NM & NM & ICP-ES \\
\hline $\mathrm{Ni}$ & $\mathrm{mg} / \mathrm{L}$ & 0.41 & 2.4 & 2.5 & 2.6 & 2.9 & ICP-ES \\
\hline $\mathrm{P}$ & $\mathrm{mg} / \mathrm{L}$ & 444 & 411 & 443 & 411 & 379 & ICP-ES \\
\hline $\mathrm{Pb}$ & $\mathrm{mg} / \mathrm{L}$ & $<0.6$ & $<0.7$ & $<0.7$ & $<0.7$ & $<0.7$ & ICP-ES \\
\hline $\mathrm{Si}$ & $\mathrm{mg} / \mathrm{L}$ & 169 & 77 & 77 & 155 & 160 & ICP-ES \\
\hline $\mathrm{Sr}$ & $\mathrm{mg} / \mathrm{L}$ & 0.09 & $<0.002$ & 0.006 & 0.05 & 0.09 & ICP-ES \\
\hline $\mathrm{Ti}$ & $\mathrm{mg} / \mathrm{L}$ & 0.15 & $<0.14$ & $<0.14$ & $<0.14$ & $<0.14$ & ICP-ES \\
\hline $\mathrm{Zn}$ & $\mathrm{mg} / \mathrm{L}$ & 3.4 & $<0.37$ & $<0.37$ & $<0.37$ & 2.8 & ICP-ES \\
\hline $\mathrm{Zr}$ & $\mathrm{mg} / \mathrm{L}$ & $<0.05$ & $<0.05$ & 0.16 & 0.11 & 0.05 & ICP-ES \\
\hline Chloride & $\mathrm{mg} / \mathrm{L}$ & 5861 & 4887 & 4915 & 4902 & 5207 & IC \\
\hline Fluoride & $\mathrm{mg} / \mathrm{L}$ & $<200$ & 248 & 249 & 236 & 145 & IC \\
\hline Formate & $\mathrm{mg} / \mathrm{L}$ & $<100$ & $<100$ & $<100$ & NM & NM & IC \\
\hline Nitrate & $\mathrm{mg} / \mathrm{L}$ & 85960 & 179766 & 166979 & 165852 & 95374 & $\mathrm{IC}$ \\
\hline Nitrite & $\mathrm{mg} / \mathrm{L}$ & 62530 & 52756 & 50871 & 49066 & 60643 & IC \\
\hline Oxalate & $\mathrm{mg} / \mathrm{L}$ & 160 & 168 & 178 & 208 & 186 & IC \\
\hline Phosphate & $\mathrm{mg} / \mathrm{L}$ & 868 & 748 & 764 & 718 & 645 & IC \\
\hline Sulfate & $\mathrm{mg} / \mathrm{L}$ & 5744 & 6648 & 6660 & 6584 & 6246 & $\mathrm{IC}$ \\
\hline TIC & $\mathrm{mg} / \mathrm{L}$ & 12314 & 8758 & 9239 & 8998 & 11770 & $\mathrm{CO}_{2}$ Evolution \\
\hline TOC & $\mathrm{mg} / \mathrm{L}$ & 3628 & 586 & 866 & 640 & 396 & $\mathrm{CO}_{2}$ Evolution \\
\hline Carbonate(TIC) & $\mathrm{mg} / \mathrm{L}$ & 61523 & 43750 & 46150 & 44950 & 58800 & Calc. from TIC \\
\hline Aluminate & Molar & 0.636 & 0.31 & 0.32 & 0.63 & 0.75 & Titration \\
\hline Carbonate & Molar & 0.763 & NM & NM & NM & NM & Titration \\
\hline Free $\mathrm{OH}$ & Molar & 1.906 & 0.83 & 0.81 & 0.72 & 2.43 & Titration \\
\hline
\end{tabular}




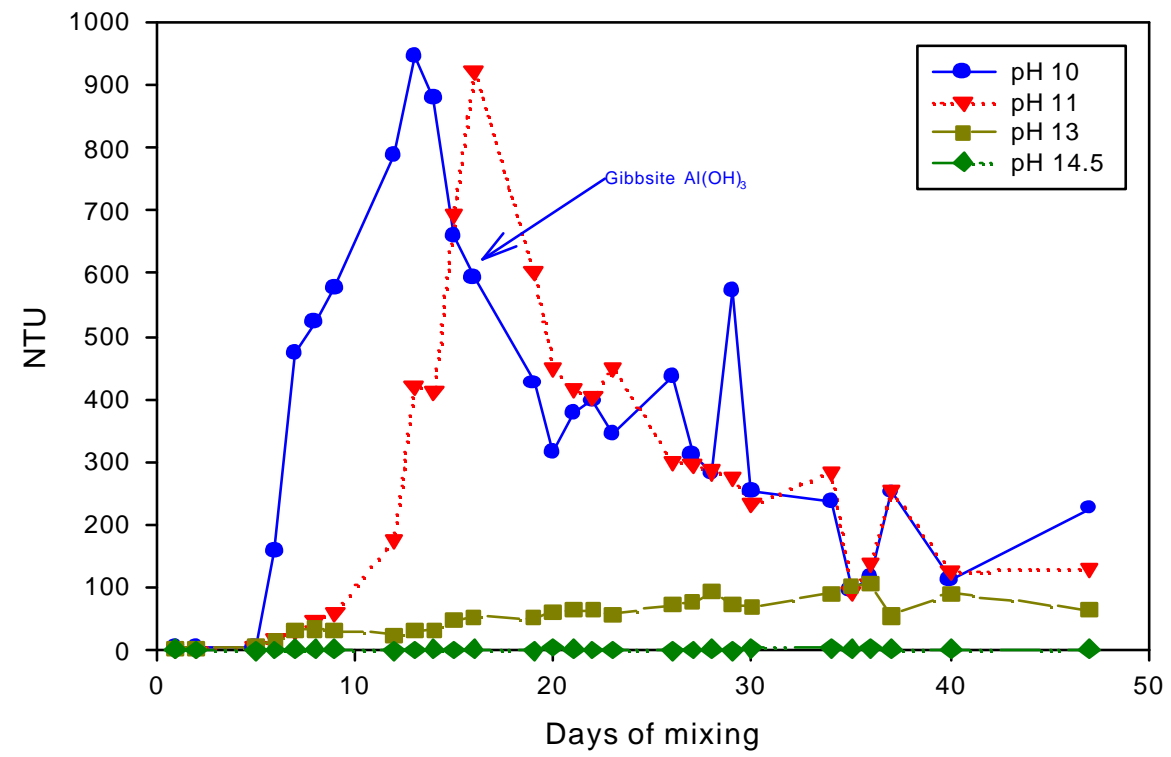

Figure 21. Turbidity of pH-Adjusted AN-104 Simulant.

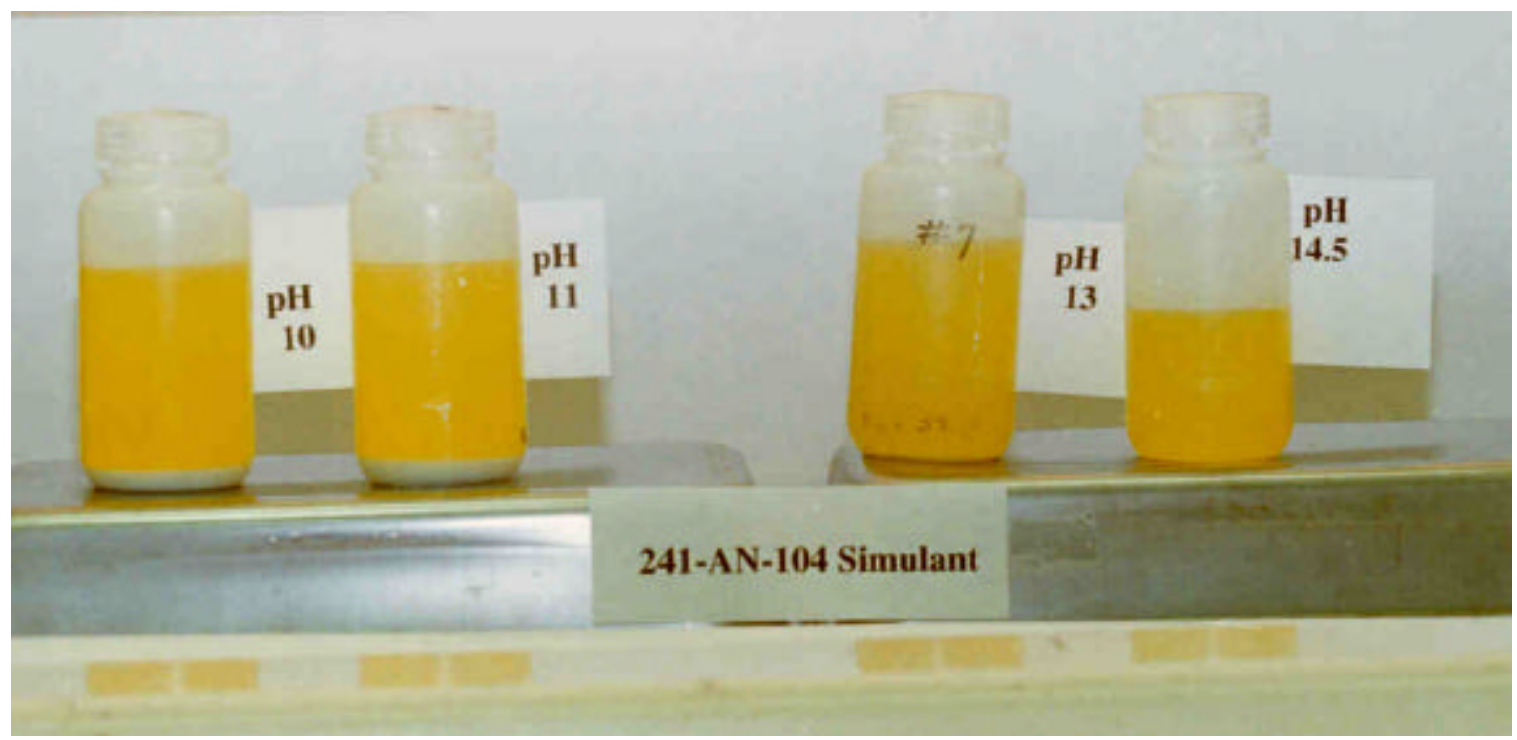

Figure 22. $\mathrm{pH}$-Adjusted AN-104 Simulant. 
Addition of acid to a high aluminate supernate such as AN-104 will destabilize the aluminate leading to precipitation of gibbsite. Addition of hydroxide to AN-104 does not produce solids. The observations are summarized in Table 23.

Table 23 Summary of pH-Adjusted AN-104 Observations.

\begin{tabular}{|c|c|c|c|c|}
\hline & & & \multicolumn{2}{|c|}{ Observed } \\
\hline Targeted pH & $\begin{array}{c}\text { Targeted[OH] } \\
(\mathbf{M})\end{array}$ & $\begin{array}{c}\text { Measured [OH] } \\
(\mathbf{M})\end{array}$ & Solids & Gas \\
\hline 10 & 0.0001 & $\sim 0.83$ & Yes & Yes \\
\hline 11 & 0.001 & $\sim 0.81$ & Yes & Yes \\
\hline 13 & 0.1 & $\sim 0.72$ & Yes & Yes \\
\hline 14.5 & 3.16 & 2.43 & No & No \\
\hline
\end{tabular}

\subsection{4. $\quad$ pH Adjustment of AW-101 Simulant}

The addition of the nitric acid to the AW-101 feed was observed to produce bubbles and a brown gas. The gas is assumed to be $\mathrm{NO}_{\mathrm{x}}$ formed from the nitrite anion due to highlocalized acid concentrations. More effective mixing might mitigate this gas evolution. Immediate formation of white solids during acid addition was observed. Addition of sodium hydroxide did not produce any observable gas or solids.

Figure 23 displays the result of monitoring turbidity for the $\mathrm{pH}$ adjusted $\mathrm{AW}-101$ simulant. The immediate formation of white solids was observed in the targeted $\mathrm{pH} 10$, 11, and 13 bottles (see footnote 2). The shape of the curve suggests that solids formation was continuing through the entire monitoring period. The solids after the first few days were observed to settle quickly leading to erratic turbidity readings. This implies that the density and probably the crystallinity of the particles were increasing over time. As indicated in Figure 23, the targeted-pH 14.5 (high hydroxide) test did not produce any solids. 
After completion of the turbidity monitoring, the test solutions were filtered using vacuum filtration through a 0.45 -micron nylon filter and the supernate submitted for analysis. Table 24 gives the results of the analysis. The filtered solids from the $\mathrm{pH} 10$ experiment were submitted for XRD to identify the solids present. The XRD scan for the acid-adjusted $\mathrm{pH} 10$ test detected the following compounds (see Appendix B, Figure B16):

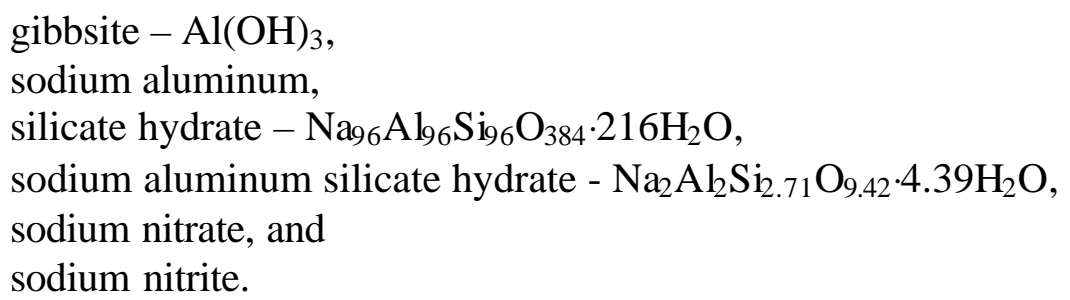

Since the solids were not washed, the sodium nitrate and sodium nitrite salts could be due to the residual supernate, which dried on the solids. The analysis of the supernate shown in Table 22 confirms the solids characterization since both Al and Si by ICP-ES show decreases in concentrations for the appropriate metal. The only other components that declined in concentration in the acid adjusted tests were sulfate and nitrite anions. The decline in nitrite was probably due to the large amount of nitric acid required by the AW101 simulant (see Table 19) as evidenced by the $\mathrm{NO}_{\mathrm{x}}$ evolution observed during acid addition. Since XRD is dominated by the bulk solids, the absence of peaks corresponding to a sulfate species is surprising. Apparently, the sulfate species was amorphous and did not yield a x-ray pattern.

The most interesting results shown in Table 24 are the free hydroxide results. Nominally,

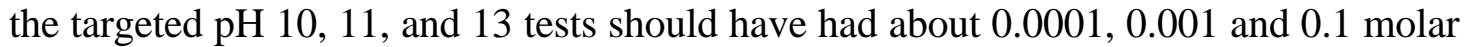
free hydroxide levels. Instead the respective free hydroxide values were $0.45,0.63$ and 0.59 molar, respectively. Since the predominant product was the precipitation of gibbsite, $\mathrm{Al}(\mathrm{OH})_{3}$, the previously cited reaction must have occurred:

$$
\mathrm{Al}(\mathrm{OH})_{4}^{-} \longrightarrow \mathrm{Al}(\mathrm{OH})_{3}+\mathrm{OH}^{-} \quad(2)
$$

As gibbsite slowly precipitates due to the dissociation of the aluminate, free hydroxide is released. 
Table 24. pH Adjustment Results for AW-101 Simulant.

\begin{tabular}{|c|c|c|c|c|c|c|c|}
\hline $\begin{array}{c}\text { Tank } \\
\text { Components }\end{array}$ & Units & $\begin{array}{c}\text { Feed } \\
\text { Found }\end{array}$ & $\begin{array}{l}\text { pH } 10 \\
\text { Found }\end{array}$ & $\begin{array}{l}\text { pH } 11 \\
\text { Found }\end{array}$ & $\begin{array}{l}\text { pH } 13 \\
\text { Found }\end{array}$ & $\begin{array}{c}\text { pH } 14.5 \\
\text { Found }\end{array}$ & $\begin{array}{r}\text { Analysis } \\
\text { Method }\end{array}$ \\
\hline $\mathrm{Ag}$ & $\mathrm{mg} / \mathrm{L}$ & $<0.3$ & $\mathrm{NM}^{\mathrm{a}}$ & $\mathrm{NM}$ & NM & $\mathrm{NM}$ & ICP-ES \\
\hline $\mathrm{Al}$ & $\mathrm{mg} / \mathrm{L}$ & 12150 & 10870 & 10917 & 10850 & 11760 & ICP-ES \\
\hline B & $\mathrm{mg} / \mathrm{L}$ & $<0.21$ & 0.7 & 0.28 & 0.32 & 0.38 & ICP-ES \\
\hline $\mathrm{Ba}$ & $\mathrm{mg} / \mathrm{L}$ & 0.12 & 0.14 & 0.13 & 0.15 & 0.18 & ICP-ES \\
\hline $\mathrm{Ca}$ & $\mathrm{mg} / \mathrm{L}$ & 2.2 & 0.55 & 0.8 & 0.79 & 0.9 & ICP-ES \\
\hline $\mathrm{Cd}$ & $\mathrm{mg} / \mathrm{L}$ & $<0.02$ & $<0.014$ & $<0.014$ & $<0.014$ & $<0.014$ & ICP-ES \\
\hline $\mathrm{Ce}$ & $\mathrm{mg} / \mathrm{L}$ & $<0.7$ & $\mathrm{NM}$ & $\mathrm{NM}$ & $\mathrm{NM}$ & $\mathrm{NM}$ & ICP-ES \\
\hline $\mathrm{Co}$ & $\mathrm{mg} / \mathrm{L}$ & $<0.05$ & $<0.044$ & $<0.044$ & $<0.044$ & $<0.044$ & ICP-ES \\
\hline $\mathrm{Cr}$ & $\mathrm{mg} / \mathrm{L}$ & 45 & 32 & 36 & 37 & 45 & ICP-ES \\
\hline Cs & $\mathrm{mg} / \mathrm{L}$ & 11.8 & $\mathrm{NM}$ & NM & NM & $\mathrm{NM}$ & AA \\
\hline $\mathrm{Cu}$ & $\mathrm{mg} / \mathrm{L}$ & 0.18 & $<0.05$ & $<0.05$ & $<0.05$ & $<0.05$ & ICP-ES \\
\hline $\mathrm{Fe}$ & $\mathrm{mg} / \mathrm{L}$ & 0.29 & 0.34 & 0.3 & 0.31 & 0.73 & ICP-ES \\
\hline $\mathrm{K}$ & $\mathrm{mg} / \mathrm{L}$ & 22730 & 21182 & 19590 & 20720 & 21710 & $\mathrm{AA}$ \\
\hline $\mathrm{La}$ & $\mathrm{mg} / \mathrm{L}$ & $<0.06$ & $<0.061$ & $<0.061$ & $<0.061$ & $<0.061$ & ICP-ES \\
\hline $\mathrm{Li}$ & $\mathrm{mg} / \mathrm{L}$ & 0.24 & $<0.1$ & $<0.1$ & $<0.1$ & 0.11 & ICP-ES \\
\hline $\mathrm{Mg}$ & $\mathrm{mg} / \mathrm{L}$ & $<0.09$ & $<0.084$ & $<0.084$ & $<0.084$ & $<0.084$ & ICP-ES \\
\hline $\mathrm{Mn}$ & $\mathrm{mg} / \mathrm{L}$ & 0.04 & 0.04 & 0.025 & 0.029 & 0.1 & ICP-ES \\
\hline Mo & $\mathrm{mg} / \mathrm{L}$ & 0.17 & 0.34 & $<0.1$ & $<0.1$ & $<0.1$ & ICP-ES \\
\hline $\mathrm{Na}$ & $\mathrm{mg} / \mathrm{L}$ & 138670 & 128134 & 124647 & 127454 & 153500 & ICP-ES \\
\hline $\mathrm{Na}$ & $\mathrm{mg} / \mathrm{L}$ & 137530 & $\mathrm{NM}$ & $\mathrm{NM}$ & $\mathrm{NM}$ & $\mathrm{NM}$ & $\mathrm{AA}$ \\
\hline $\mathrm{Nd}$ & $\mathrm{mg} / \mathrm{L}$ & $<0.03$ & $\mathrm{NM}$ & NM & NM & $\mathrm{NM}$ & ICP-ES \\
\hline $\mathrm{Ni}$ & $\mathrm{mg} / \mathrm{L}$ & 0.32 & 0.62 & 0.64 & 0.73 & 0.94 & ICP-ES \\
\hline $\mathrm{P}$ & $\mathrm{mg} / \mathrm{L}$ & 343 & 297 & 292 & 297 & 262 & ICP-ES \\
\hline $\mathrm{Pb}$ & $\mathrm{mg} / \mathrm{L}$ & 28 & 28 & 29 & 28 & 30 & ICP-ES \\
\hline $\mathrm{Si}$ & $\mathrm{mg} / \mathrm{L}$ & 125 & 57 & 72 & 73 & 110 & ICP-ES \\
\hline $\mathrm{Sr}$ & $\mathrm{mg} / \mathrm{L}$ & 0.11 & 0.08 & 0.078 & 0.075 & 0.11 & ICP-ES \\
\hline $\mathrm{Ti}$ & $\mathrm{mg} / \mathrm{L}$ & $<0.14$ & $<0.14$ & $<0.14$ & $<0.14$ & $<0.14$ & ICP-ES \\
\hline $\mathrm{Zn}$ & $\mathrm{mg} / \mathrm{L}$ & 15 & 7.8 & 12 & 12 & 15 & ICP-ES \\
\hline $\mathrm{Zr}$ & $\mathrm{mg} / \mathrm{L}$ & 0.06 & $<0.048$ & 0.11 & $<0.048$ & 0.5 & ICP-ES \\
\hline Chloride & $\mathrm{mg} / \mathrm{L}$ & 2570 & 3430 & 3205 & 3439 & 3583 & $\mathrm{IC}$ \\
\hline Fluoride & $\mathrm{mg} / \mathrm{L}$ & 112 & 430 & 386 & 457 & 456 & $\mathrm{IC}$ \\
\hline Formate & $\mathrm{mg} / \mathrm{L}$ & $<100$ & $<100$ & $<100$ & $<100$ & $<100$ & $\mathrm{IC}$ \\
\hline Nitrate & $\mathrm{mg} / \mathrm{L}$ & 105344 & 210322 & 184258 & 201678 & 109016 & $\mathrm{IC}$ \\
\hline Nitrite & $\mathrm{mg} / \mathrm{L}$ & 59905 & 42576 & 43293 & 47905 & 56742 & IC \\
\hline Oxalate & $\mathrm{mg} / \mathrm{L}$ & $<100$ & $<100$ & $<100$ & $<100$ & $<100$ & IC \\
\hline Phosphate & $\mathrm{mg} / \mathrm{L}$ & 799 & 657 & 638 & 666 & 510 & $\mathrm{IC}$ \\
\hline Sulfate & $\mathrm{mg} / \mathrm{L}$ & 2403 & 1479 & 1353 & 1497 & 1596 & $\mathrm{IC}$ \\
\hline TIC & $\mathrm{mg} / \mathrm{L}$ & 9620 & 3995 & 4394 & 4838 & 8355 & $\mathrm{CO}_{2}$ Evolution \\
\hline TOC & $\mathrm{mg} / \mathrm{L}$ & $<200$ & 378 & 183 & 167 & $<100$ & $\mathrm{CO}_{2}$ Evolution \\
\hline Carbonate(TIC) & $\mathrm{mg} / \mathrm{L}$ & 48063 & 19960 & 21950 & 24170 & 41740 & Calc. from TIC \\
\hline Aluminate & Molar & 0.365 & 0.44 & 0.43 & 0.43 & 0.54 & Titration \\
\hline Carbonate & Molar & 0.454 & NM & NM & NM & NM & Titration \\
\hline Free $\mathrm{OH}$ & Molar & 2.133 & 0.45 & 0.63 & 0.59 & 2.64 & Titration \\
\hline
\end{tabular}




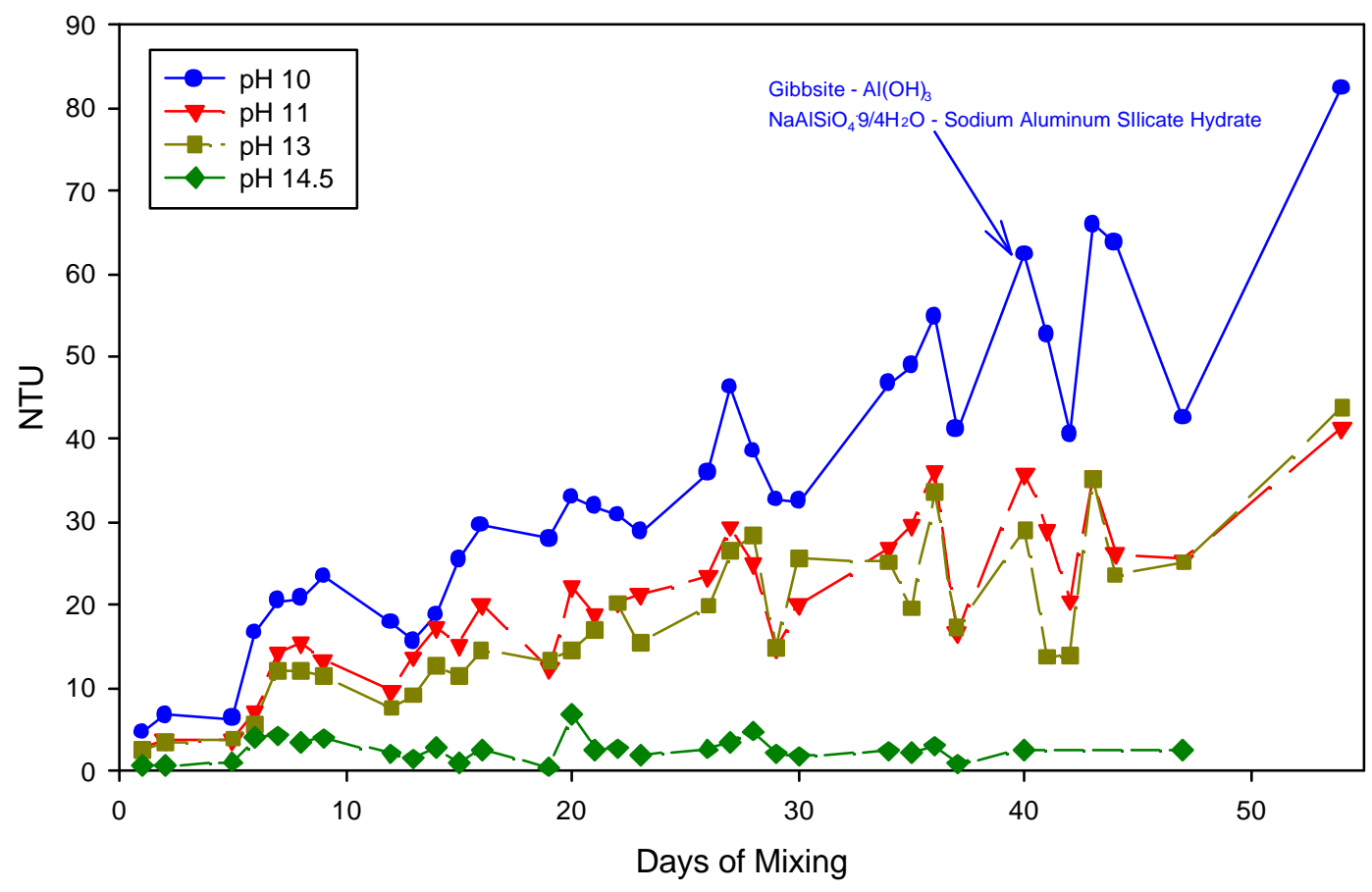

Figure 23. Turbidity of pH-Adjusted AW-101 Simulant. 
Addition of acid to a high aluminate supernate such as AW-101 will destabilize the aluminate leading to precipitation of Gibbsite. If sufficient soluble silicon is present, sodium aluminosilicates will also precipitate. Addition of hydroxide to AW-101 does not produce solids. The observations are summarized in Table 25.

Table 25. Summary of pH Adjusted AW-101 Observations.

\begin{tabular}{|c|c|c|c|c|}
\hline & & & \multicolumn{2}{|c|}{ Observed } \\
\hline Targeted pH & $\begin{array}{c}\text { Targeted[OH] } \\
(\mathbf{M})\end{array}$ & $\begin{array}{c}\text { Measured }[\mathbf{O H}] \\
(\mathbf{M})\end{array}$ & Solids & Gas \\
\hline 10 & 0.0001 & $\sim 0.45$ & Yes & Yes \\
\hline 11 & 0.001 & $\sim 0.63$ & Yes & Yes \\
\hline 13 & 0.1 & $\sim 0.59$ & Yes & Yes \\
\hline 14.5 & 3.16 & 2.64 & No & No \\
\hline
\end{tabular}

\subsection{5. $\quad$ pH Adjustment of AZ-101 Simulant}

Brown gas formed when nitric acid was added to the AZ-101 feed. The gas is assumed to be $\mathrm{NO}_{\mathrm{x}}$ formed from the nitrite anion due to high-localized acid concentrations. More effective mixing might mitigate this gas evolution. Immediate formation of white solids during acid addition was observed. Addition of sodium hydroxide did not produce any observable gas.

Figure 24 displays the result of monitoring turbidity for the $\mathrm{pH}$ adjusted AZ-101 simulant. The immediate formation of white solids was observed in the targeted $\mathrm{pH} 10$ and 13 bottles (see footnote 2). The solids after the first few days were observed to settle quickly leading to erratic turbidity readings. This implies that the density and probably the crystallinity of the particles were increasing over time. The shape of the curve clearly supports the observation. Unlike the two A envelope simulants, the $\mathrm{pH} 14.5$ test shown in Figure 24 indicates the formation of solids due to hydroxide addition. The data while erratic was supported by visible observations.

After completion of the turbidity monitoring, the tests solutions were filtered using vacuum filtration through a 0.45 -micron nylon filter and the supernate submitted for analysis. Table 26 gives the results of the analysis. The filtered solids from the targeted pH 10 experiment were submitted for XRD to identify the solids present. The XRD scan for the acid-adjusted $\mathrm{pH} 10$ test detected the following compounds (see appendix B Figure B17):

Gibbsite $-\mathrm{Al}(\mathrm{OH})_{3}$, sodium nitrate, and sodium nitrite. 
Since the solids were not washed, the sodium nitrate and sodium nitrite salts could be due to the residual supernate, which dried on the solids. The analysis of the supernate shown in Table 26 confirms the solids characterization since $\mathrm{Al}$ by ICP-ES and $\mathrm{Al}(\mathrm{OH})_{4}{ }^{-}$by titration drop in concentration. The only other components that declined in concentration in the acid adjusted tests were Si and TIC. Since XRD is dominated by amorphous or low-crystalline solids, the absence of sharp peaks associated with Si species is understandable. This suggests that the precipitated Si formed non-crystalline precipitates. The components that declined in concentration in the high hydroxide adjustment were fluoride, phosphate and sulfate. This suggests that the solids may have been double salts of the fluorophosphate and fluorosulfate type.

Nominally, the pH 10, 11, and 13 tests should have had about $0.0001,0.001$ and 0.1 molar free hydroxide levels Table 26). Instead the respective free hydroxide values were $0.16,0.18$ and 0.33 molar. Since the predominant product was the precipitation of Gibbsite, $\mathrm{Al}(\mathrm{OH})_{3}$, the previously cited reaction must have occurred:

$$
\mathrm{Al}(\mathrm{OH})_{4}{ }^{-} \longrightarrow \mathrm{Al}(\mathrm{OH})_{3}+\mathrm{OH}^{-}
$$

As Gibbsite slowly precipitates due to the dissociation of the aluminate, free hydroxide is released. 
Table 26. Composition of pH-Adjusted AZ-101 Simulant.

\begin{tabular}{|c|c|c|c|c|c|c|c|}
\hline $\begin{array}{c}\text { Tank } \\
\text { Components }\end{array}$ & Units & $\begin{array}{c}\text { Feed } \\
\text { Found }\end{array}$ & $\begin{array}{l}\text { pH } 10 \\
\text { Found }\end{array}$ & $\begin{array}{l}\text { pH } 11 \\
\text { Found }\end{array}$ & $\begin{array}{l}\text { pH } 13 \\
\text { Found }\end{array}$ & $\begin{array}{c}\text { pH } 14.5 \\
\text { Found }\end{array}$ & $\begin{array}{r}\text { Analysis } \\
\text { Method }\end{array}$ \\
\hline $\mathrm{Al}$ & $\mathrm{mg} / \mathrm{L}$ & 7752 & 1611 & 1750 & 1960 & 7691 & ICP-ES \\
\hline $\mathrm{B}$ & $\mathrm{mg} / \mathrm{L}$ & $<0.21$ & $<0.21$ & $<0.21$ & $<0.21$ & $<0.21$ & ICP-ES \\
\hline $\mathrm{Ba}$ & $\mathrm{mg} / \mathrm{L}$ & 0.02 & $<0.012$ & $<0.012$ & $<0.012$ & 0.11 & ICP-ES \\
\hline $\mathrm{Ca}$ & $\mathrm{mg} / \mathrm{L}$ & 3.7 & 0.12 & 0.14 & 0.09 & 1.6 & ICP-ES \\
\hline $\mathrm{Ce}$ & $\mathrm{mg} / \mathrm{L}$ & $<0.7$ & $\mathrm{NM}^{\mathrm{a}}$ & $\mathrm{NM}$ & $\mathrm{NM}$ & $\mathrm{NM}$ & ICP-ES \\
\hline $\mathrm{Cr}$ & $\mathrm{mg} / \mathrm{L}$ & 648 & 657 & 651 & 650 & 627 & ICP-ES \\
\hline Cs & $\mathrm{mg} / \mathrm{L}$ & 41 & $\mathrm{NM}$ & $\mathrm{NM}$ & $\mathrm{NM}$ & $\mathrm{NM}$ & ICP-ES \\
\hline $\mathrm{Fe}$ & $\mathrm{mg} / \mathrm{L}$ & 0.46 & $<0.044$ & $<0.044$ & $<0.044$ & 0.43 & ICP-ES \\
\hline $\mathrm{K}$ & $\mathrm{mg} / \mathrm{L}$ & 4690 & 4728 & 4791 & 4785 & 4368 & $\mathrm{AA}$ \\
\hline $\mathrm{La}$ & $\mathrm{mg} / \mathrm{L}$ & $<0.06$ & $<0.06$ & $<0.06$ & $<0.06$ & $<0.06$ & ICP-ES \\
\hline $\mathrm{Li}$ & $\mathrm{mg} / \mathrm{L}$ & 0.18 & $<0.1$ & $<0.1$ & $<0.1$ & $<0.1$ & ICP-ES \\
\hline $\mathrm{Mg}$ & $\mathrm{mg} / \mathrm{L}$ & $<0.09$ & $<0.09$ & $<0.09$ & $<0.09$ & $<0.09$ & ICP-ES \\
\hline $\mathrm{Mn}$ & $\mathrm{mg} / \mathrm{L}$ & 0.11 & $<0.009$ & $<0.009$ & $<0.009$ & $<0.009$ & ICP-ES \\
\hline Mo & $\mathrm{mg} / \mathrm{L}$ & $<0.1$ & 6.5 & $<0.1$ & $<0.1$ & $<0.1$ & ICP-ES \\
\hline $\mathrm{Na}$ & $\mathrm{mg} / \mathrm{L}$ & 104670 & 104740 & 109238 & 110376 & 145997 & ICP-ES \\
\hline $\mathrm{Na}$ & $\mathrm{mg} / \mathrm{L}$ & 108990 & NM & NM & NM & $\mathrm{NM}$ & AA \\
\hline $\mathrm{Ni}$ & $\mathrm{mg} / \mathrm{L}$ & 0.34 & 7.3 & 7.2 & 7.0 & 7.6 & ICP-ES \\
\hline $\mathrm{P}$ & $\mathrm{mg} / \mathrm{L}$ & 546 & 486 & 536 & 525 & 505 & ICP-ES \\
\hline $\mathrm{Si}$ & $\mathrm{mg} / \mathrm{L}$ & 5.3 & $<0.7$ & $<0.7$ & $<0.7$ & $<0.7$ & ICP-ES \\
\hline $\mathrm{Zr}$ & $\mathrm{mg} / \mathrm{L}$ & 0.32 & 0.54 & 0.3 & 0.16 & 0.22 & ICP-ES \\
\hline Chloride & $\mathrm{mg} / \mathrm{L}$ & 180 & 1540 & 1541 & 1561 & 1493 & IC \\
\hline Fluoride & $\mathrm{mg} / \mathrm{L}$ & 760 & 1709 & 1838 & 2007 & 479 & $\mathrm{IC}$ \\
\hline Formate & $\mathrm{mg} / \mathrm{L}$ & $<100$ & $<100$ & $<100$ & $<100$ & $<100$ & IC \\
\hline Nitrate & $\mathrm{mg} / \mathrm{L}$ & 60330 & 92095 & 98074 & 93977 & 67967 & IC \\
\hline Nitrite & $\mathrm{mg} / \mathrm{L}$ & 61770 & 57993 & 62251 & 62641 & 55853 & $\mathrm{IC}$ \\
\hline Oxalate & $\mathrm{mg} / \mathrm{L}$ & $<100$ & 310 & $<100$ & $<100$ & $<100$ & IC \\
\hline Phosphate & $\mathrm{mg} / \mathrm{L}$ & 1318 & 1223 & 1327 & 1341 & 935 & $\mathrm{IC}$ \\
\hline Sulfate & $\mathrm{mg} / \mathrm{L}$ & 15740 & 16925 & 17036 & 17207 & 9907 & IC \\
\hline TIC & $\mathrm{mg} / \mathrm{L}$ & 8466 & 6911 & 7163 & 8028 & 11430 & $\mathrm{CO}_{2}$ Evolution \\
\hline TOC & $\mathrm{mg} / \mathrm{L}$ & 365 & 222 & 188 & $<100$ & 173 & $\mathrm{CO}_{2}$ Evolution \\
\hline Carbonate(TIC) & $\mathrm{mg} / \mathrm{L}$ & 42298 & 34525 & 35780 & 40105 & 57100 & Calc. from TIC \\
\hline Aluminate & Molar & 0.268 & 0.13 & 0.12 & 0.13 & 0.36 & Titration \\
\hline Carbonate & Molar & 0.384 & NM & NM & NM & $\mathrm{NM}$ & Titration \\
\hline Free $\mathrm{OH}$ & Molar & 0.463 & 0.16 & 0.18 & 0.33 & 2.31 & Titration \\
\hline
\end{tabular}




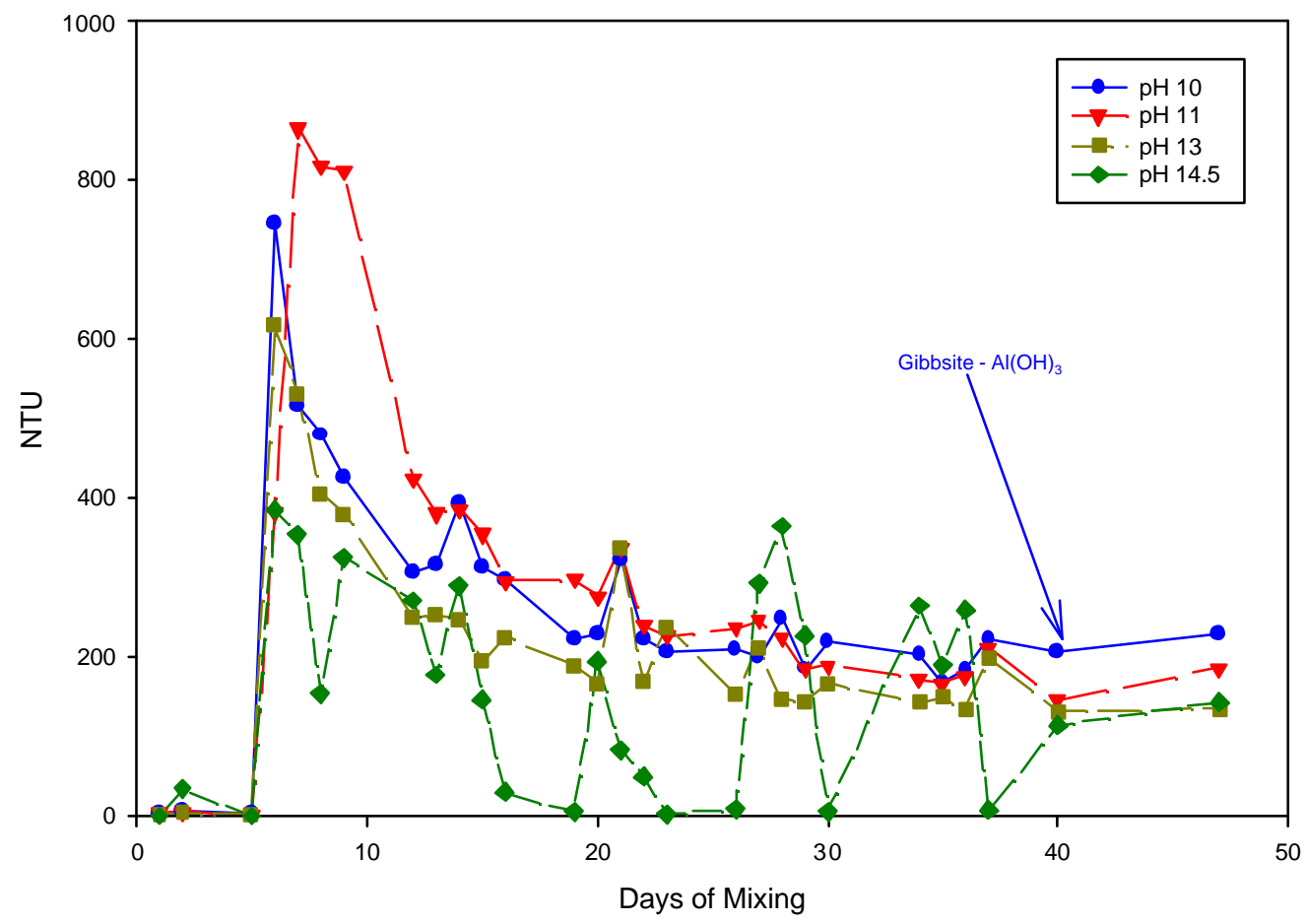

Figure 24. Turbidity of pH-Adjusted AZ-101 Simulant. 
Addition of acid to a high aluminate supernate such as AZ-101 will destabilize the aluminate leading to precipitation of Gibbsite. Addition of hydroxide to AZ-101 does produce solids. Since the AZ-101 simulant is based upon the Best Basis Inventory and not an actual sample analysis, a better test of B envelope feed will be the AZ-102 simulant. The observations are summarized in Table 27.

Table 27. Summary of pH Adjusted AZ-101 Observations.

\begin{tabular}{|c|c|c|c|c|}
\hline & & & \multicolumn{2}{|c|}{ Observed } \\
\hline Targeted pH & $\begin{array}{c}\text { Targeted[OH] } \\
(\mathbf{M})\end{array}$ & $\begin{array}{c}\text { Measured [OH] } \\
(\mathbf{M})\end{array}$ & Solids & Gas \\
\hline 10 & 0.0001 & $\sim 0.16$ & Yes & Yes \\
\hline 11 & 0.001 & $\sim 0.18$ & Yes & Yes \\
\hline 13 & 0.1 & 0.33 & Yes & Yes \\
\hline 14.5 & 3.16 & 2.31 & Yes & No \\
\hline
\end{tabular}

\subsection{6. $\quad$ pH Adjustment of AZ-102 Simulant}

Brown gas was observed when nitric acid was added to the AZ-102 feed. The gas is assumed to be $\mathrm{NO}_{\mathrm{x}}$ formed from the nitrite anion due to high-localized acid concentrations. More effective mixing might mitigate this gas evolution. Immediate formation of white solids during acid addition was observed. Addition of sodium hydroxide did not produce any observable gas or solids.

Figure 25 displays the result of monitoring turbidity for the $\mathrm{pH}$ adjusted AZ-102 simulant. Fine solids were observed in all three $\mathrm{pH}$ adjusted tests from the very first day of monitoring. The apparent delay in turbidity was the result of not swirling the bottle before removing a sample for turbidity measurements. Once gentle agitation was used, the readings became stable and agreed with the visual observations. The turbidity plot also indicates that fewer solids were probably present in the targeted $\mathrm{pH} 13$ test than in the other two acid-adjusted tests. As indicated in Figure 25, the $\mathrm{pH} 14.5$ (high hydroxide) test did not produce any solids in contrast to the AZ-101 test.

After completion of the turbidity monitoring, the test solutions were filtered using vacuum filtration through a 0.45 -micron nylon filter and the supernate submitted for analysis. Table 28 gives the results of the analysis. The filtered solids from the $\mathrm{pH} 11$ experiment were submitted for XRD to identify the solids present. The XRD scan for the acid-adjusted $\mathrm{pH} 11$ test detected the following compounds (see Appendix B, Figure B18):

gibbsite $-\mathrm{Al}(\mathrm{OH})_{3}$, sodium aluminum silicate $-\mathrm{Na}_{1.84} \mathrm{Al}_{2} \mathrm{Si}_{2.88} \mathrm{O}_{9.68}$, 
sodium nitrate, and

sodium nitrite.

Since the solids were not washed, the sodium nitrate and sodium nitrite salts could be due to the residual supernate, which dried on the solids as XRD-detectable evaporates. The analysis of the supernate shown in Table 28 confirms the solids identified by XRD, since both $\mathrm{Si}$ by ICP-ES and $\mathrm{Al}(\mathrm{OH})_{4}$ by titration show drops in concentration. The only other components that declined in concentration in the acid adjusted tests were $\mathrm{Ca}$ and TIC. Despite the observation of $\mathrm{NO}_{\mathrm{x}}$, no evidence of a decline in nitrite concentration can be found in Table 28. Since XRD patterns were dominated by the presence of amorphous or poorly crystalline solids, the lack of $\mathrm{Ca}$ and carbonate solids in the XRD pattern is understandable. XRD identifies only crystalline minerals, thus few of the precipitates formed during the study could be identified by XRD. Since the aluminate level was so low in the AZ-102 simulant, the free hydroxide concentrations were less than detection limit as planned for this experiment. 
Table 28. Composition of pH-Adjusted AZ-102 Simulant.

\begin{tabular}{|c|c|c|c|c|c|c|c|}
\hline $\begin{array}{c}\text { Tank } \\
\text { Components }\end{array}$ & Units & $\begin{array}{c}\text { Feed } \\
\text { Found }\end{array}$ & $\begin{array}{l}\text { pH } 10 \\
\text { Found }\end{array}$ & $\begin{array}{l}\text { pH 11 } \\
\text { Found }\end{array}$ & $\begin{array}{l}\text { pH } 13 \\
\text { Found }\end{array}$ & $\begin{array}{c}\text { pH } 14.5 \\
\text { Found }\end{array}$ & $\begin{array}{c}\text { Analysis } \\
\text { Method }\end{array}$ \\
\hline $\mathrm{Ag}$ & $\mathrm{mg} / \mathrm{L}$ & $<0.3$ & $\mathrm{NM}^{\mathrm{a}}$ & NM & NM & NM & ICP-ES \\
\hline $\mathrm{Al}$ & $\mathrm{mg} / \mathrm{L}$ & 230 & 9.7 & 290 & 149 & 223 & ICP-ES \\
\hline $\mathrm{B}$ & $\mathrm{mg} / \mathrm{L}$ & 7.3 & 6.6 & 5.8 & 7.1 & 6.8 & ICP-ES \\
\hline $\mathrm{Ba}$ & $\mathrm{mg} / \mathrm{L}$ & 0.01 & $<0.012$ & $<0.012$ & $<0.012$ & 0.09 & ICP-ES \\
\hline $\mathrm{Ca}$ & $\mathrm{mg} / \mathrm{L}$ & 4.8 & 2.9 & 1.2 & 0.6 & 4.3 & ICP-ES \\
\hline $\mathrm{Cd}$ & $\mathrm{mg} / \mathrm{L}$ & 0.05 & $<0.014$ & $<0.014$ & $<0.014$ & 0.04 & ICP-ES \\
\hline $\mathrm{Ce}$ & $\mathrm{mg} / \mathrm{L}$ & $<0.7$ & NM & NM & NM & NM & ICP-ES \\
\hline Co & $\mathrm{mg} / \mathrm{L}$ & $<0.05$ & $<0.044$ & $<0.044$ & $<0.044$ & $<0.044$ & ICP-ES \\
\hline $\mathrm{Cr}$ & $\mathrm{mg} / \mathrm{L}$ & 865 & 831 & 822 & 872 & 803 & ICP-ES \\
\hline Cs & $\mathrm{mg} / \mathrm{L}$ & 1 & NM & NM & NM & NM & ICP-ES \\
\hline $\mathrm{Cu}$ & $\mathrm{mg} / \mathrm{L}$ & 0.18 & $<0.05$ & $<0.05$ & $<0.05$ & 0.09 & ICP-ES \\
\hline $\mathrm{Fe}$ & $\mathrm{mg} / \mathrm{L}$ & 0.23 & 0.06 & $<0.044$ & 0.05 & 0.58 & ICP-ES \\
\hline $\mathrm{K}$ & $\mathrm{mg} / \mathrm{L}$ & 3150 & 3150 & 3422 & 3224 & 2914 & $\mathrm{AA}$ \\
\hline $\mathrm{La}$ & $\mathrm{mg} / \mathrm{L}$ & $<0.06$ & $<0.061$ & $<0.061$ & $<0.061$ & $<0.061$ & ICP-ES \\
\hline $\mathrm{Li}$ & $\mathrm{mg} / \mathrm{L}$ & 0.12 & $<0.1$ & $<0.1$ & $<0.1$ & $<0.1$ & ICP-ES \\
\hline $\mathrm{Mg}$ & $\mathrm{mg} / \mathrm{L}$ & $<0.09$ & $<0.084$ & $<0.084$ & $<0.084$ & $<0.084$ & ICP-ES \\
\hline $\mathrm{Mn}$ & $\mathrm{mg} / \mathrm{L}$ & $<0.009$ & $<0.009$ & $<0.009$ & $<0.009$ & 0.013 & ICP-ES \\
\hline Mo & $\mathrm{mg} / \mathrm{L}$ & 58 & 58 & 51 & 59 & 53 & ICP-ES \\
\hline $\mathrm{Na}$ & $\mathrm{mg} / \mathrm{L}$ & 58070 & 62137 & 65248 & 61590 & 111131 & ICP-ES \\
\hline $\mathrm{Na}$ & $\mathrm{mg} / \mathrm{L}$ & 53000 & NM & NM & NM & NM & AA \\
\hline $\mathrm{Nd}$ & $\mathrm{mg} / \mathrm{L}$ & $<0.3$ & NM & NM & NM & NM & ICP-ES \\
\hline $\mathrm{Ni}$ & $\mathrm{mg} / \mathrm{L}$ & $<0.06$ & 9.2 & 9.2 & 9.8 & 9.5 & ICP-ES \\
\hline $\mathrm{P}$ & $\mathrm{mg} / \mathrm{L}$ & 166 & 150 & 201 & 162 & 148 & ICP-ES \\
\hline $\mathrm{Pb}$ & $\mathrm{mg} / \mathrm{L}$ & $<0.6$ & $<0.7$ & $<0.7$ & $<0.7$ & 1.4 & ICP-ES \\
\hline $\mathrm{Si}$ & $\mathrm{mg} / \mathrm{L}$ & 121 & 4.1 & 5.6 & 21 & 118 & ICP-ES \\
\hline $\mathrm{Sn}$ & $\mathrm{mg} / \mathrm{L}$ & $<0.26$ & $<0.26$ & $<0.26$ & $<0.26$ & $<0.26$ & ICP-ES \\
\hline $\mathrm{Sr}$ & $\mathrm{mg} / \mathrm{L}$ & 0.05 & 0.013 & 0.014 & 0.006 & 0.07 & ICP-ES \\
\hline $\mathrm{Ti}$ & $\mathrm{mg} / \mathrm{L}$ & $<0.14$ & $<0.014$ & $<0.014$ & $<0.014$ & $<0.014$ & ICP-ES \\
\hline $\mathrm{V}$ & $\mathrm{mg} / \mathrm{L}$ & $<0.13$ & $<0.013$ & $<0.013$ & $<0.013$ & $<0.013$ & ICP-ES \\
\hline $\mathrm{Zn}$ & $\mathrm{mg} / \mathrm{L}$ & $<0.37$ & $<0.37$ & $<0.37$ & $<<0.37$ & $<0.37$ & ICP-ES \\
\hline $\mathrm{Zr}$ & $\mathrm{mg} / \mathrm{L}$ & 0.43 & 0.31 & 0.17 & 0.78 & 0.44 & ICP-ES \\
\hline Chloride & $\mathrm{mg} / \mathrm{L}$ & 201 & 280 & 280 & 282 & 188 & IC \\
\hline Fluoride & $\mathrm{mg} / \mathrm{L}$ & 1111 & 1001 & 1019 & 938 & 821 & IC \\
\hline Formate & $\mathrm{mg} / \mathrm{L}$ & $<100$ & $<100$ & $<100$ & $<100$ & $<100$ & IC \\
\hline Nitrate & $\mathrm{mg} / \mathrm{L}$ & 15360 & 35640 & 42978 & 28782 & 14808 & IC \\
\hline Nitrite & $\mathrm{mg} / \mathrm{L}$ & 31050 & 31099 & 35079 & 31289 & 28496 & IC \\
\hline Oxalate & $\mathrm{mg} / \mathrm{L}$ & 2671 & 2568 & 2271 & 2597 & 763 & IC \\
\hline Phosphate & $\mathrm{mg} / \mathrm{L}$ & 375 & 488 & 584 & 513 & 505 & IC \\
\hline Sulfate & $\mathrm{mg} / \mathrm{L}$ & 14848 & 15507 & 15568 & 15570 & 14051 & IC \\
\hline TIC & $\mathrm{mg} / \mathrm{L}$ & 8946 & 6778 & 7188 & 7466 & 12720 & $\mathrm{CO}_{2}$ Evolution \\
\hline TOC & $\mathrm{mg} / \mathrm{L}$ & 1052 & 930 & 932 & 988 & 386 & $\mathrm{CO}_{2}$ Evolution \\
\hline Carbonate(TIC) & $\mathrm{mg} / \mathrm{L}$ & 44696 & 33864 & 35913 & 37302 & 63551 & Calc. from TIC \\
\hline Aluminate & Molar & 0.030 & $<0.02$ & $<0.02$ & $<0.02$ & 0.146 & Titration \\
\hline Carbonate & Molar & 0.464 & NM & NM & $\mathrm{NM}$ & NM & Titration \\
\hline Free $\mathrm{OH}$ & Molar & 0.196 & $<0.02$ & $<0.02$ & $<0.02$ & 2.17 & Titration \\
\hline
\end{tabular}



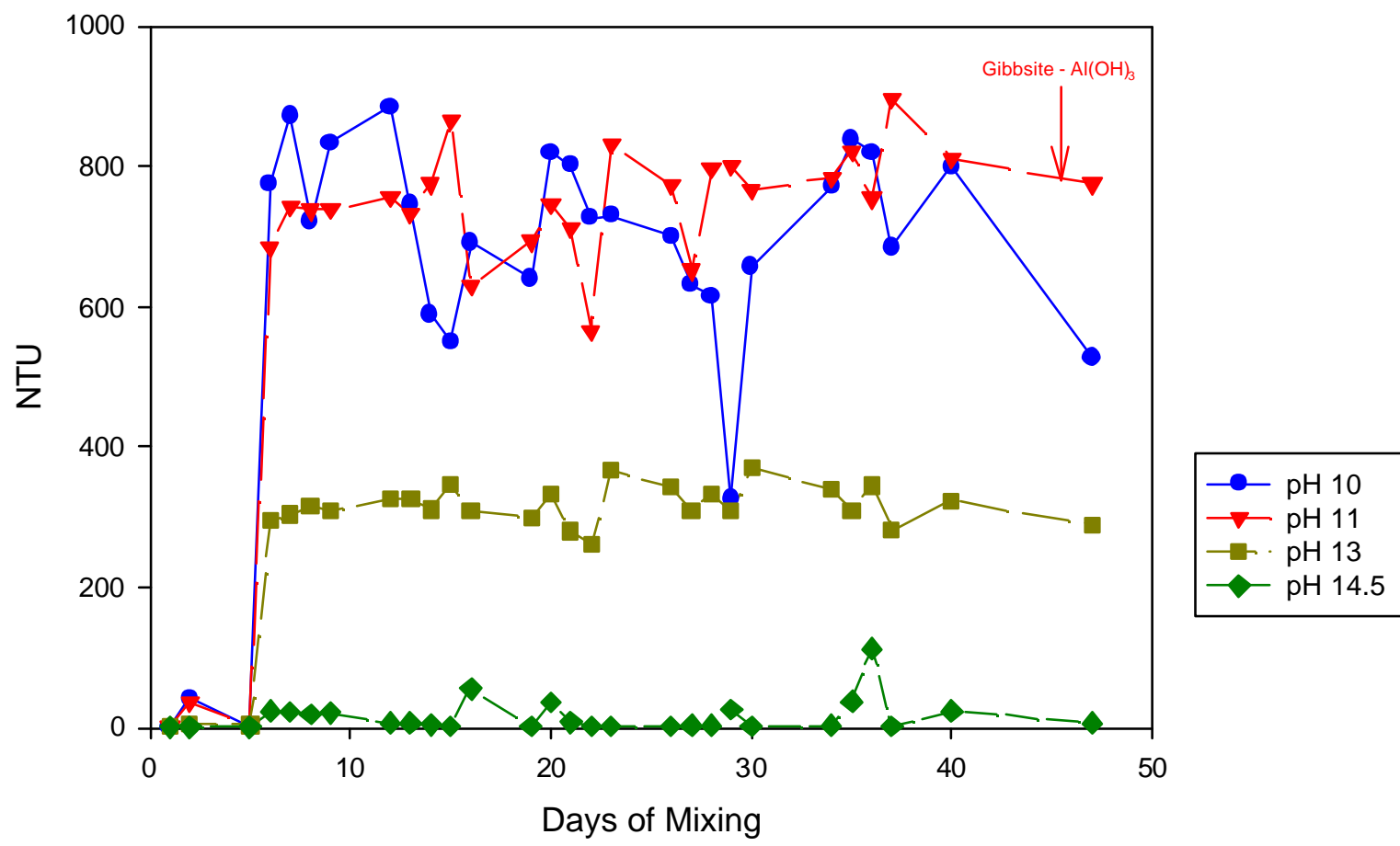

Figure 25. Turbidity of pH-Adjusted AZ-102 Simulant.

Addition of acid to an Envelope B supernate such as AZ-102 will destabilize the aluminate leading to precipitation of Gibbsite and production of aluminosilicates. Addition of hydroxide to AZ-102 does not produce solids. The observations are summarized in Table 29. 
Table 29. Summary of pH Adjusted AZ-102 Observations.

\begin{tabular}{|c|c|c|c|c|}
\hline \multicolumn{2}{|c|}{} & \multicolumn{2}{c|}{ Observed } \\
\hline Targeted pH & $\begin{array}{c}\text { Targeted[OH] } \\
(\mathbf{M})\end{array}$ & $\begin{array}{c}\text { Measured }[\mathbf{O H}] \\
(\mathbf{M})\end{array}$ & Solids & Gas \\
\hline 10 & 0.0001 & $<0.02$ & Yes & Yes \\
\hline 11 & 0.001 & $<0.02$ & Yes & Yes \\
\hline 13 & 0.1 & $<0.02$ & Yes & Yes \\
\hline 14.5 & 3.16 & 2.17 & No & No \\
\hline
\end{tabular}

\subsection{Envelope-D Leachate Mixing Experiment}

The reader is directed to Kaplan et al. (2000; SRT-RPP-2000-00016) for discussion, details and conclusions concerning this experiment. The analytical results presented in this section are for general information and the final report (Kaplan et al. 2000) should be consulted before using or trying to interpret these results.

This group of experiments is designed to evaluate whether the recycle of leachate from caustic washing of Envelope D sludge will produce solids upon addition to feed tanks containing Envelope A, B or C supernates. The specific mixtures tested are listed in the experimental design in Table 1. The experimental methodology is presented in more detail in Section 3.5. Only results for AN-107 and C-106 caustic leachate mixtures are discussed in detail because the other mixtures did not result in appreciably amounts of precipitation. These other tests confirm and mimic results obtained from caustic testing with Envelopes A and B; the AN-107 and C-106 mixtures did not mimic results from caustic testing. 


\subsubsection{AN-107 and C-106 Caustic Leachate Mixtures}

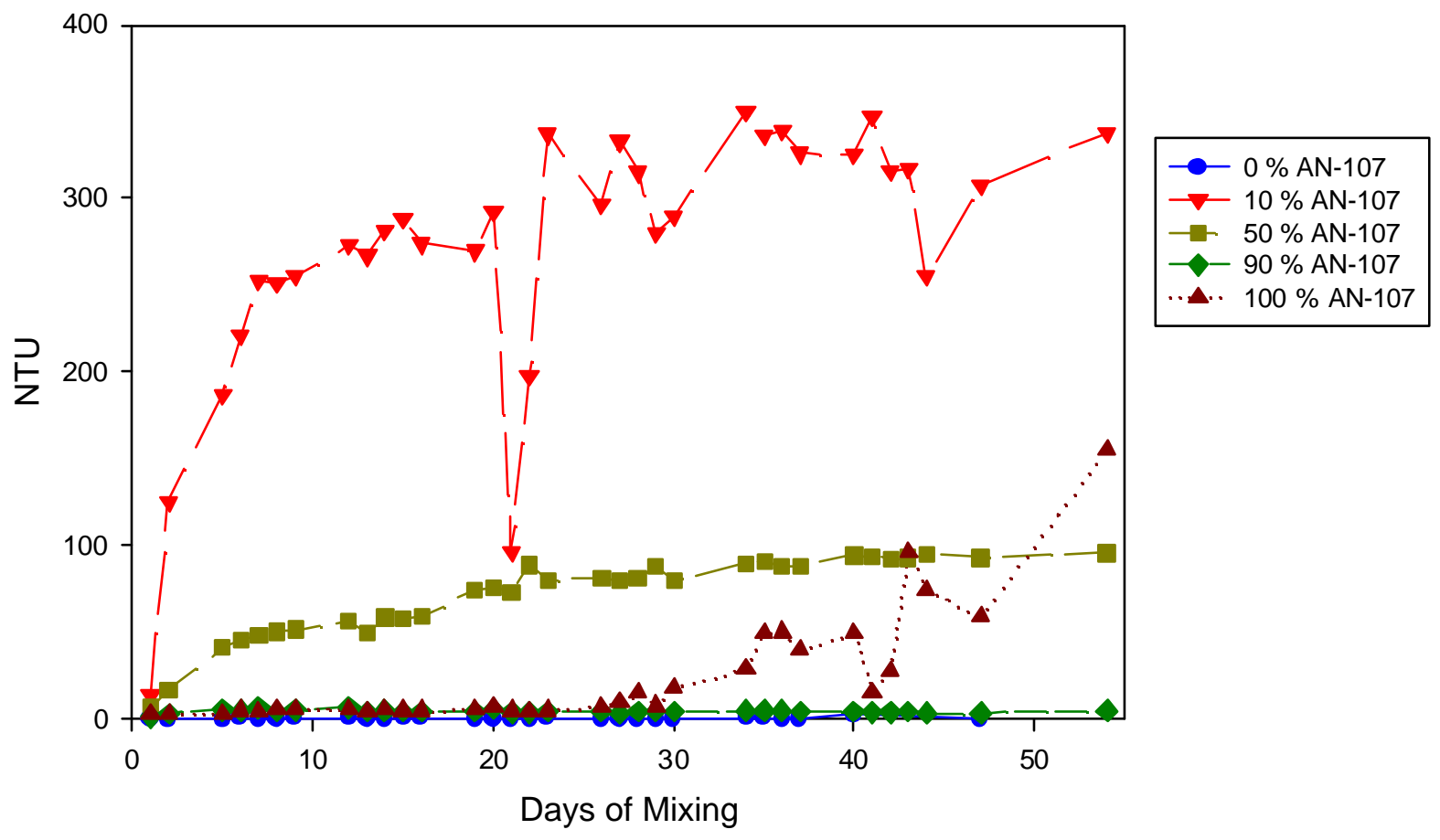

Figure 26. Turbidity of AN-107 \& C-106 Leachate Simulant Mixtures.

X-Ray Diffraction Results for Filtered Solids from the 50:50 Mixture of AN-107 and C106 Leachate

Sodium Aluminum Silicate Hydrate - $\mathrm{Na}_{12.8} \mathrm{Al}_{7.2} \mathrm{Si}_{16.8} \mathrm{O}_{48}\left(\mathrm{H}_{2} \mathrm{O}\right)_{6}$ Sodium Carbonate Hydrogen Peroxide $-\mathrm{Na}_{2} \mathrm{CO}_{3}\left(\mathrm{H}_{2} \mathrm{O}_{2}\right)_{1.5}$

Sodium Nitrate and Sodium Nitrite were also detected but since the solids were not washed this would be due to the residual supernate which dried on the solids. 
Table 30. Composition of 50:50 Mixture of AN-107 and C-106 Leachate.

\begin{tabular}{|c|c|c|c|c|c|c|}
\hline Tank & Units & $\begin{array}{c}\text { AN-107 } \\
\text { Found }\end{array}$ & \begin{tabular}{|c|} 
C-106 Leachate \\
Found
\end{tabular} & $\begin{array}{l}\text { 50\% Mix } \\
\text { Expected }\end{array}$ & $\begin{array}{l}\text { 50\% Mix } \\
\text { Found }\end{array}$ & $\begin{array}{l}\text { \% of Expected } \\
\text { in } 50 \% \text { Mixture }\end{array}$ \\
\hline$\overline{\mathrm{Al}}$ & $\mathrm{mg} / \mathrm{L}$ & 194 & 2460 & 1349 & 1360 & 101 \\
\hline B & $\mathrm{mg} / \mathrm{L}$ & 38 & 68 & 54 & 56 & 104 \\
\hline $\mathrm{Ba}$ & $\mathrm{mg} / \mathrm{L}$ & 0.17 & 14.6 & 7 & 0.16 & 2 \\
\hline$\overline{\mathrm{Ca}}$ & $\mathrm{mg} / \mathrm{L}$ & 138 & 3.3 & 72 & 83 & 115 \\
\hline $\mathrm{Cd}$ & $\mathrm{mg} / \mathrm{L}$ & $<0.02$ & $<0.02$ & $<0.02$ & $<0.014$ & $\overline{\mathrm{NA}}$ \\
\hline $\mathrm{Ce}$ & $\mathrm{mg} / \mathrm{L}$ & 50.2 & $<0.7$ & 26 & $\mathrm{NM}^{*}$ & $\overline{\mathrm{NA}}$ \\
\hline $\mathrm{Co}$ & $\mathrm{mg} / \mathrm{L}$ & 0.39 & $<0.05$ & 0.2 & $<0.044$ & $\overline{\mathrm{NA}}$ \\
\hline $\mathrm{Cr}$ & $\mathrm{mg} / \mathrm{L}$ & 148 & 49 & 100 & 110 & 110 \\
\hline Cs & $\mathrm{mg} / \mathrm{L}$ & 22.3 & 0.7 & 12 & NM & NA \\
\hline $\mathrm{Cu}$ & $\mathrm{mg} / \mathrm{L}$ & 32 & 0.06 & 16 & 21 & 131 \\
\hline $\mathrm{Fe}$ & $\mathrm{mg} / \mathrm{L}$ & 1623 & 0.24 & 825 & 675 & 82 \\
\hline $\mathrm{K}$ & $\mathrm{mg} / \mathrm{L}$ & 1921 & 2.4 & 978 & 11990 & 1226 \\
\hline $\mathrm{La}$ & $\mathrm{mg} / \mathrm{L}$ & 40 & $<0.06$ & 21 & 20 & 95 \\
\hline $\mathrm{Mg}$ & $\mathrm{mg} / \mathrm{L}$ & 20 & $<0.09$ & 10 & 1 & 10 \\
\hline $\mathrm{Mn}$ & $\mathrm{mg} / \mathrm{L}$ & 564 & 0.02 & 287 & 146 & 51 \\
\hline Mo & $\mathrm{mg} / \mathrm{L}$ & 36 & $<0.1$ & 18 & 21 & 117 \\
\hline $\mathrm{Na}$ & $\mathrm{mg} / \mathrm{L}$ & 188170 & 105670 & 149385 & 161228 & 108 \\
\hline $\mathrm{Na}$ & $\mathrm{mg} / \mathrm{L}$ & 201400 & 102470 & 154484 & $\mathrm{NM}$ & $\overline{\mathrm{NA}}$ \\
\hline $\mathrm{Nd}$ & $\mathrm{mg} / \mathrm{L}$ & 84.4 & $<0.3$ & 43 & NM & NA \\
\hline $\mathrm{Ni}$ & $\mathrm{mg} / \mathrm{L}$ & 501 & 0.06 & 255 & 297 & 116 \\
\hline$\overline{\mathrm{P}}$ & $\mathrm{mg} / \mathrm{L}$ & 420 & 125 & 278 & 308 & 111 \\
\hline $\mathrm{Pb}$ & $\mathrm{mg} / \mathrm{L}$ & 364 & 26 & 198 & 199 & 101 \\
\hline $\mathrm{Si}$ & $\mathrm{mg} / \mathrm{L}$ & 1.4 & 303 & 155 & 138 & 89 \\
\hline $\mathrm{Sr}$ & $\mathrm{mg} / \mathrm{L}$ & 1.3 & 0.06 & 0.7 & 0.62 & 89 \\
\hline $\mathrm{Zn}$ & $\mathrm{mg} / \mathrm{L}$ & 44 & 0.48 & 23 & 25 & 109 \\
\hline $\mathrm{Zr}$ & $\mathrm{mg} / \mathrm{L}$ & 45 & $<0.05$ & 23 & 25 & 109 \\
\hline Chloride & $\mathrm{mg} / \mathrm{L}$ & 1330 & 105 & 676 & 2552 & 378 \\
\hline Fluoride & $\mathrm{mg} / \mathrm{L}$ & 3430 & $<20$ & 1744 & 306 & 18 \\
\hline Formate & $\mathrm{mg} / \mathrm{L}$ & 11232 & $<100$ & 5710 & $<100$ & NA \\
\hline Nitrate & $\mathrm{mg} / \mathrm{L}$ & 213930 & 241 & 108882 & 64845 & 60 \\
\hline Nitrite & $\mathrm{mg} / \mathrm{L}$ & 57090 & 6589 & 32374 & 37304 & 115 \\
\hline Oxalate & $\mathrm{mg} / \mathrm{L}$ & 335 & 698 & 525 & 366 & 70 \\
\hline Phosphate & $\mathrm{mg} / \mathrm{L}$ & 1500 & 303 & 917 & 572 & 62 \\
\hline Sulfate & $\mathrm{mg} / \mathrm{L}$ & 7280 & 1570 & 4499 & 1747 & 39 \\
\hline TIC & $\mathrm{mg} / \mathrm{L}$ & 16100 & 3 & 8186 & 14500 & 177 \\
\hline TOC & $\mathrm{mg} / \mathrm{L}$ & 15800 & 18716 & 17548 & 1713 & 10 \\
\hline Carbonate(TIC) & $\mathrm{mg} / \mathrm{L}$ & 80439 & 13 & 40901 & 72434 & 177 \\
\hline Aluminate & Molar & 0.054 & 0.070 & 0.063 & 0.38 & 603 \\
\hline Carbonate & Molar & 1.052 & 0.881 & 0.983 & -- & $\overline{\mathrm{NA}}$ \\
\hline Free $\mathrm{OH}$ & Molar & 0.039 & 2.651 & 1.368 & 2.02 & 148 \\
\hline
\end{tabular}




\subsubsection{A and B Envelopes Mixed with Caustic Leachates}

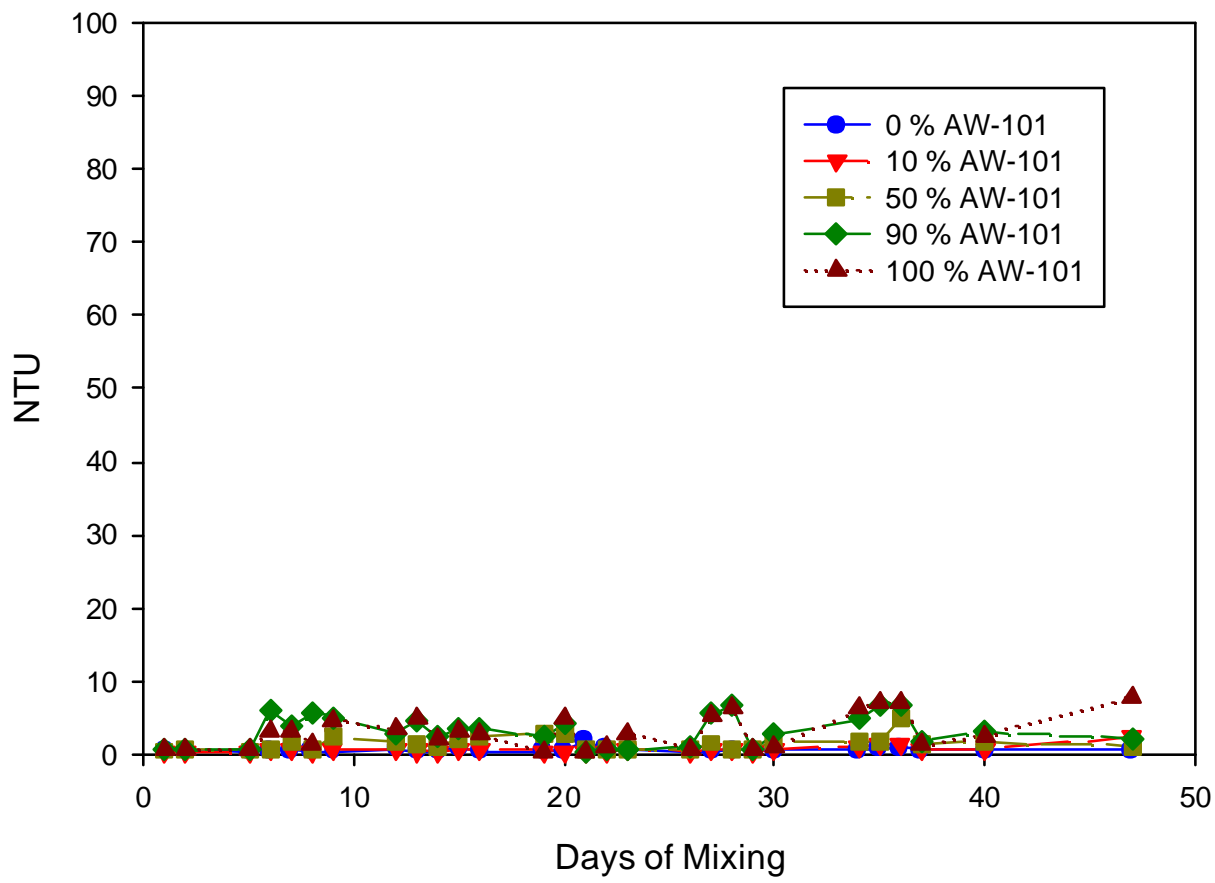

Figure 27. Turbidity of AW-101 \& C-106 Leachate Simulant Mixtures. 


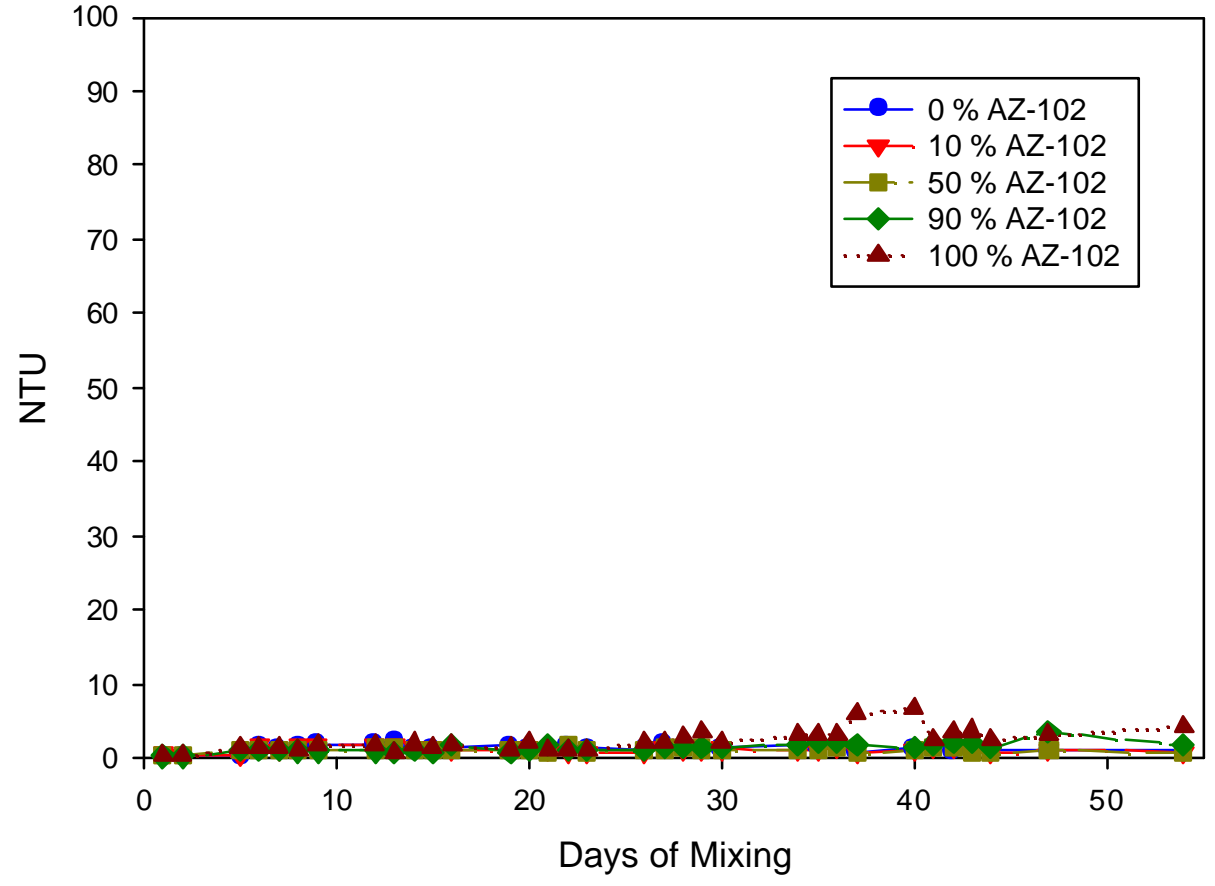

Figure 28. Turbidity of AZ-102 \& AZ-102 Leachate Mixtures. 


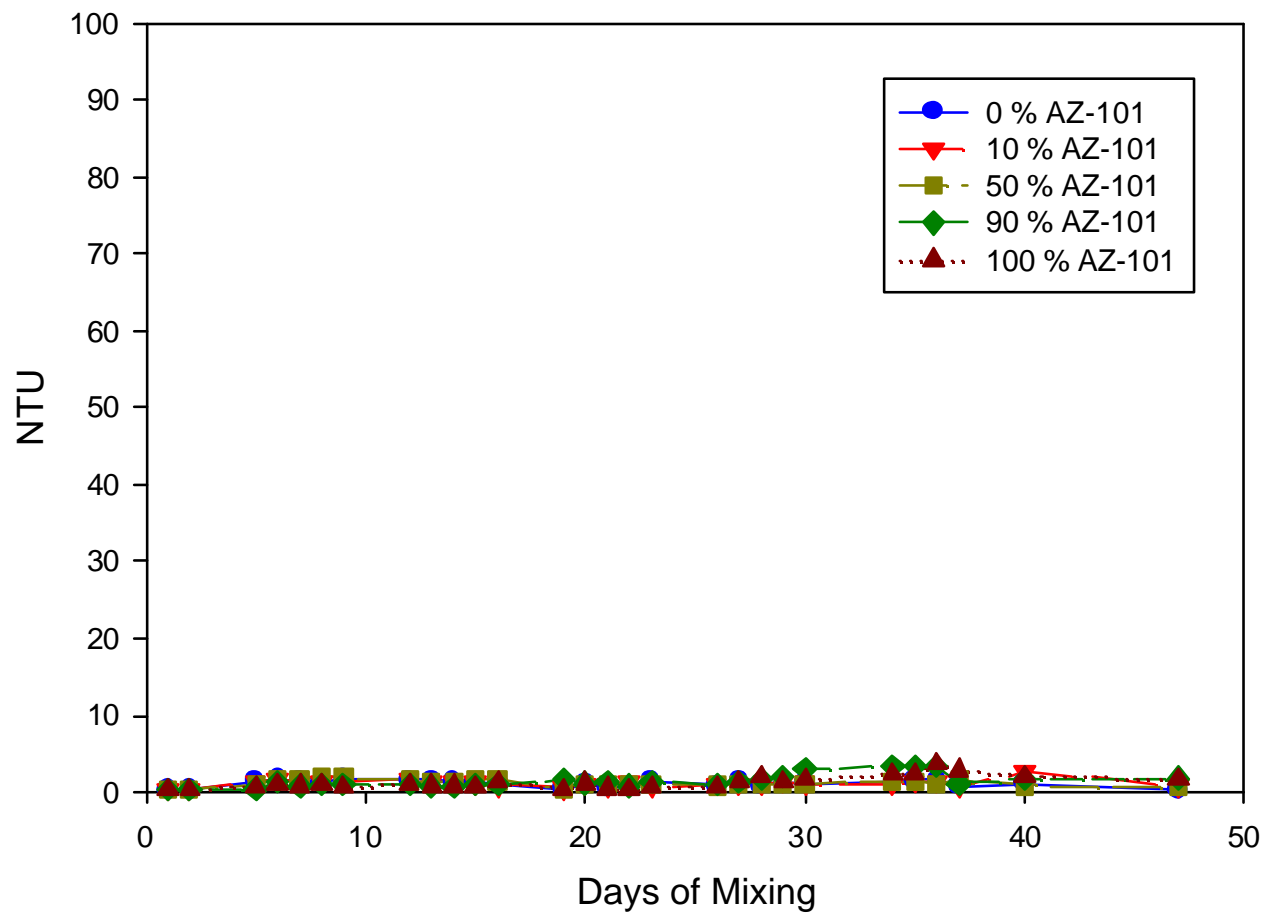

Figure 29. Turbidity of AZ-101 and AZ-102 Leachate Mixtures. 


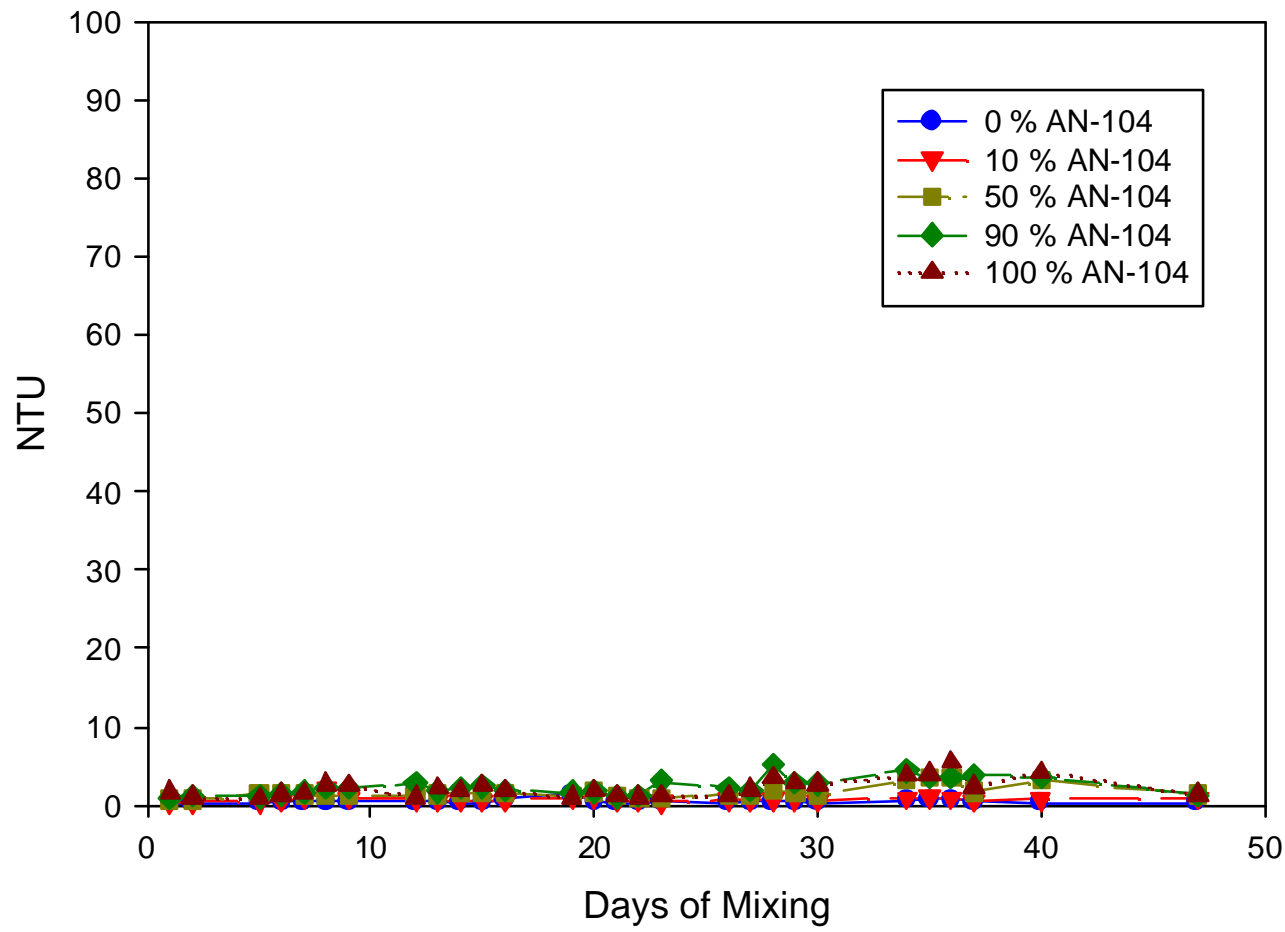

Figure 30. Turbidity of AN-104 and C-106 Leachate Mixtures. 


\section{REFERENCES}

1. Johnson, M. E., Test Specification for Mixing of Process, Heels, Process, Solutions, and Recycle Streams: Small-Scale Radioactive. Rev.0, January 29, 1999, BNFL Inc., Richland, WA.

2. Herting, D. L., Caustic Leaching of Sludge Sample from Tank 241-AZ102. Letter 75764-PCS95-086, Rev. 0, September 29, 1995.

3. Herting, D. L., Results of Dilution Studies with Waste from Tank 241AN-105, HNF-SD-WM-DTR-046, Rev. 0, September 1997.

4. Herting, D. L., Results of Dilution Studies with Waste from Tank 241AN-104, HNF-3352, Rev. 0, September 1998.

5. Brooks, K. P., Myers, R. L., Rappe, K. G., Bench-Scale Enhanced Sludge Washing and Gravity Settling of Hanford Tank C-106 Sludge, PNNL11432, January 1997.

6. R. A. Esch, Tank Waste Remediation System (TWRS) Privatization Private Contractor Sample Waste Envelope C Material Tank 241-AN-107, HNF-SD-WM-DP-205, Rev. 1, April 1997.

7. Urie, M. W., Wagner, J. J., Greenwood, L. R., Farmer, O. T., Fiskum, S. K., Ratner, R. T., Soderquist, C. Z., Inorganic and Radiochemical Analysis of AW-101 and AN-107 "Diluted Feed" Materials, PNWD-2463 Rev. 1, BNFL-RPT-003 Rev. 1, September 1999.

8. Hay, M. S., Bronikowski, M. G., Chemical Characterization of An Envelope B/D Sample from Hanford Tank 241-AZ-102, BNF-003-890249, August 2000.

9. Gray, W. J., Peterson, M. E., Scheele, R. D., Tingey, J. M., Characterization of the First Core Sample of Neutralized Current Acid Waste From Double-Shell Tank 102-AZ, Pacific Northwest Laboratory, January 1993.

10. Hodgson, K. M., Tank Characterization Report for Double-Shell Tank 241-AZ-101, WHC-SD-WM-ER-410, July 26, 1995.

11. Kaplan, D. I., Eibling, R. E., McCabe, D. J., Mixing of Process Heels, Process Solutions, and recycle Streams: Small-Scale Simulant, SRT-RPP2000-00016, January 15, 2001. 
Table A1. Suspension Temperatures During Dilution and Envelope Mixing Experiments.

\begin{tabular}{cccccc}
\hline Date & $\begin{array}{c}\text { Day since } \\
\text { Mixing }\end{array}$ & Degrees C & Date & $\begin{array}{c}\text { Day since } \\
\text { Mixing }\end{array}$ & Degrees C \\
\hline $1 / 12 / 00$ & 1 & 23 & $2 / 14 / 00$ & 34 & 21 \\
$1 / 13 / 00$ & 2 & 23 & $2 / 15 / 00$ & 35 & 20 \\
$1 / 17 / 00$ & 6 & 23 & $2 / 16 / 00$ & 36 & 20 \\
$1 / 18 / 00$ & 7 & 22 & $2 / 17 / 00$ & 37 & 20 \\
$1 / 19 / 00$ & 8 & 22 & $2 / 22 / 00$ & 42 & 20 \\
$1 / 20 / 00$ & 9 & 22 & $2 / 23 / 00$ & 43 & 20 \\
$1 / 24 / 00$ & 13 & 25 & $2 / 28 / 00$ & 48 & 20 \\
$1 / 25 / 00$ & 14 & 26 & $2 / 29 / 00$ & 49 & 20 \\
$1 / 26 / 00$ & 15 & 26 & $3 / 1 / 00$ & 50 & 20 \\
$1 / 27 / 00$ & 16 & 23 & $3 / 2 / 00$ & 51 & 21 \\
$1 / 31 / 00$ & 20 & 21 & $3 / 6 / 00$ & 55 & 20 \\
$2 / 1 / 00$ & 21 & 21 & $3 / 7 / 00$ & 56 & 20 \\
$2 / 2 / 00$ & 22 & 20 & $3 / 8 / 00$ & 57 & 21 \\
$2 / 3 / 00$ & 23 & 20 & $3 / 9 / 00$ & 58 & 21 \\
$2 / 7 / 00$ & 27 & 20 & $3 / 16 / 00$ & 35 & 21 \\
$2 / 8 / 00$ & 28 & 20 & & & \\
$2 / 9 / 00$ & 29 & 20 & AVERAGE & 21.3 & \\
$2 / 10 / 00$ & 30 & 20 & STD DEV & 1.7 & \\
$2 / 14 / 00$ & 34 & 21 & &
\end{tabular}


Figure A1. Temperature Variations during the Hydroxide Adjustment and Leaching Mixing Studies.

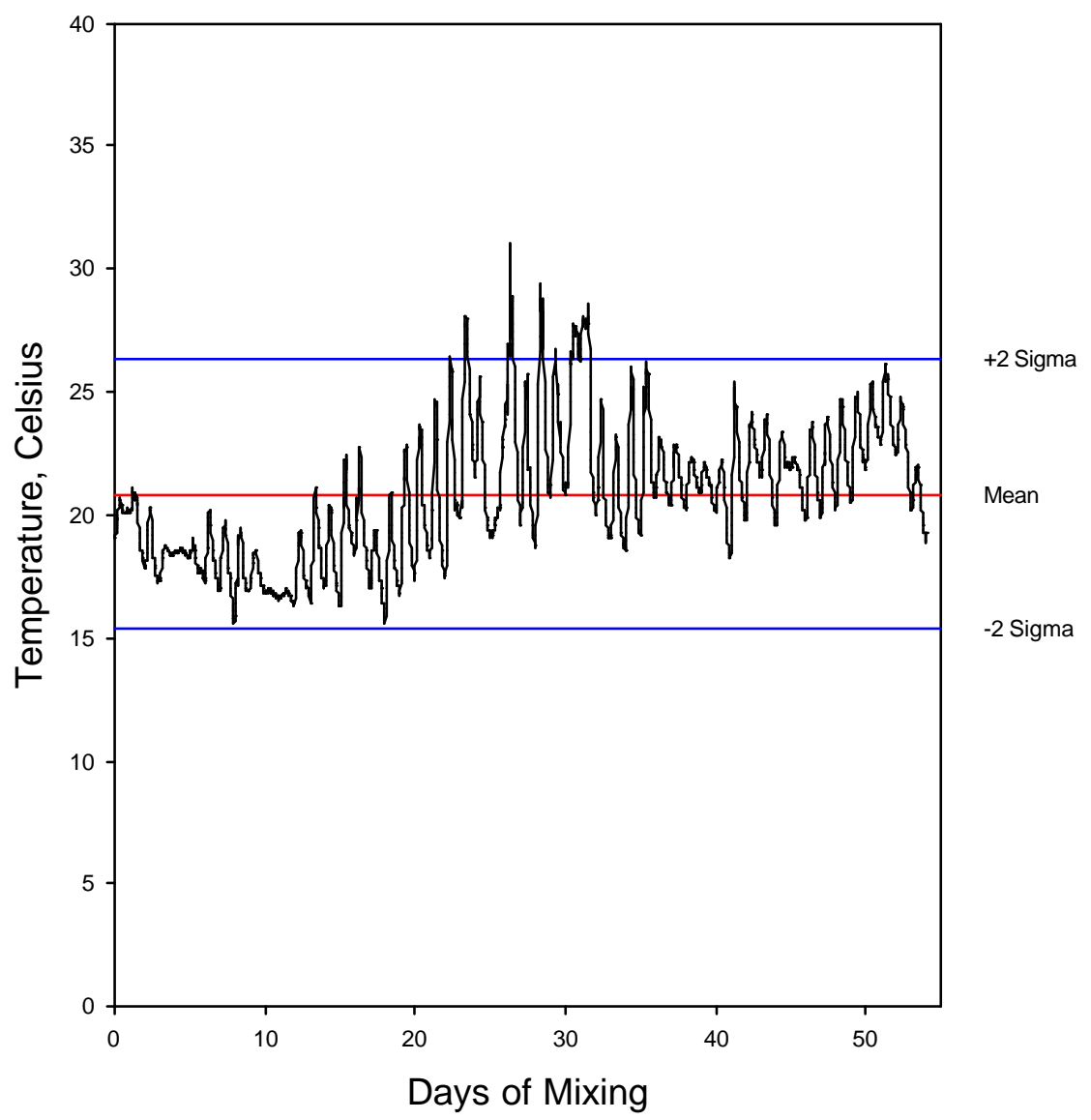


7. APPENDIX B. XRD DATA 
Figure B1. XRD Spectrum of Solids from 100\% AN-107.

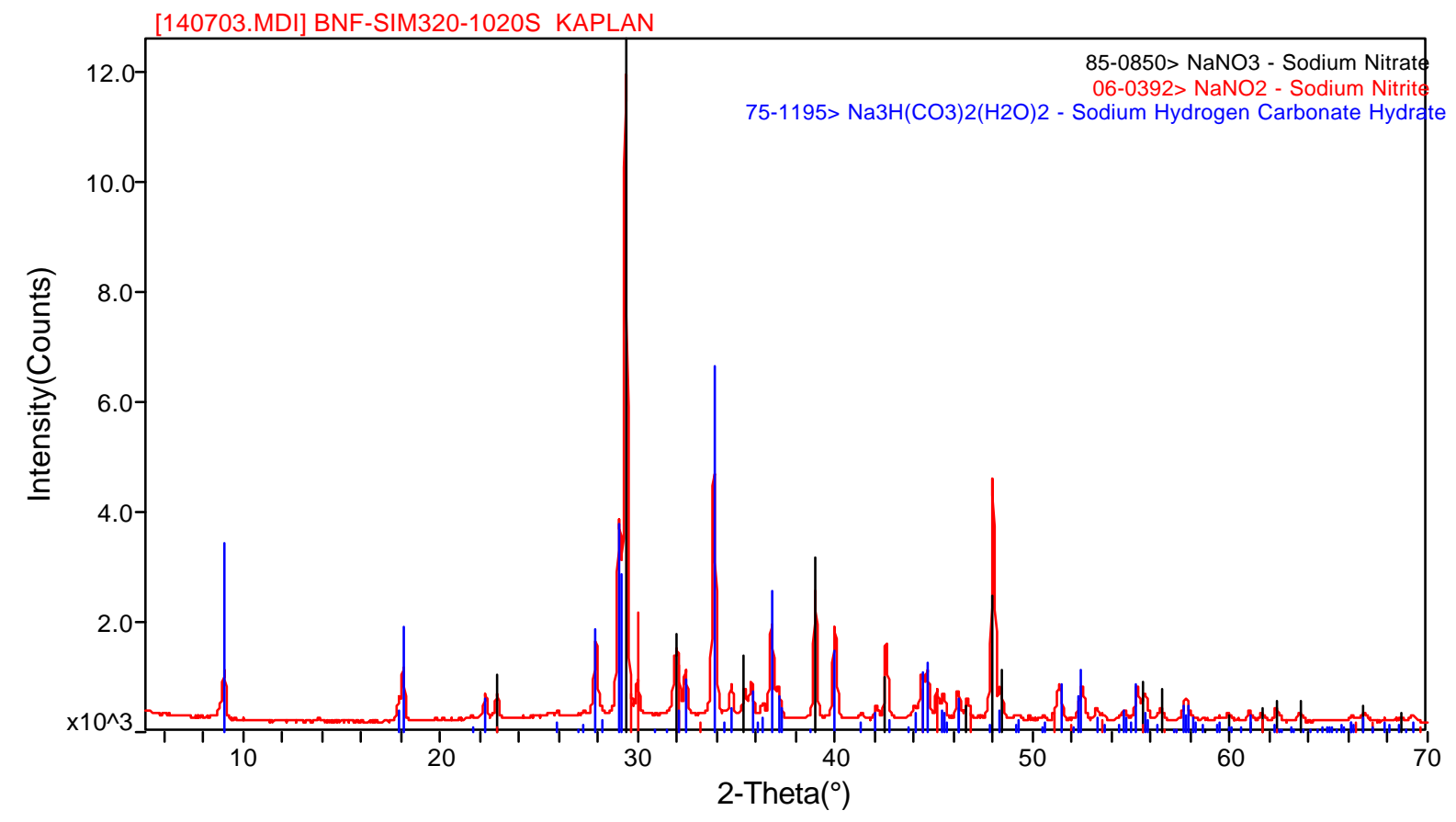


Figure B2. XRD Spectrum of Solids from 10\% AZ-101 / 90\% AN-107.

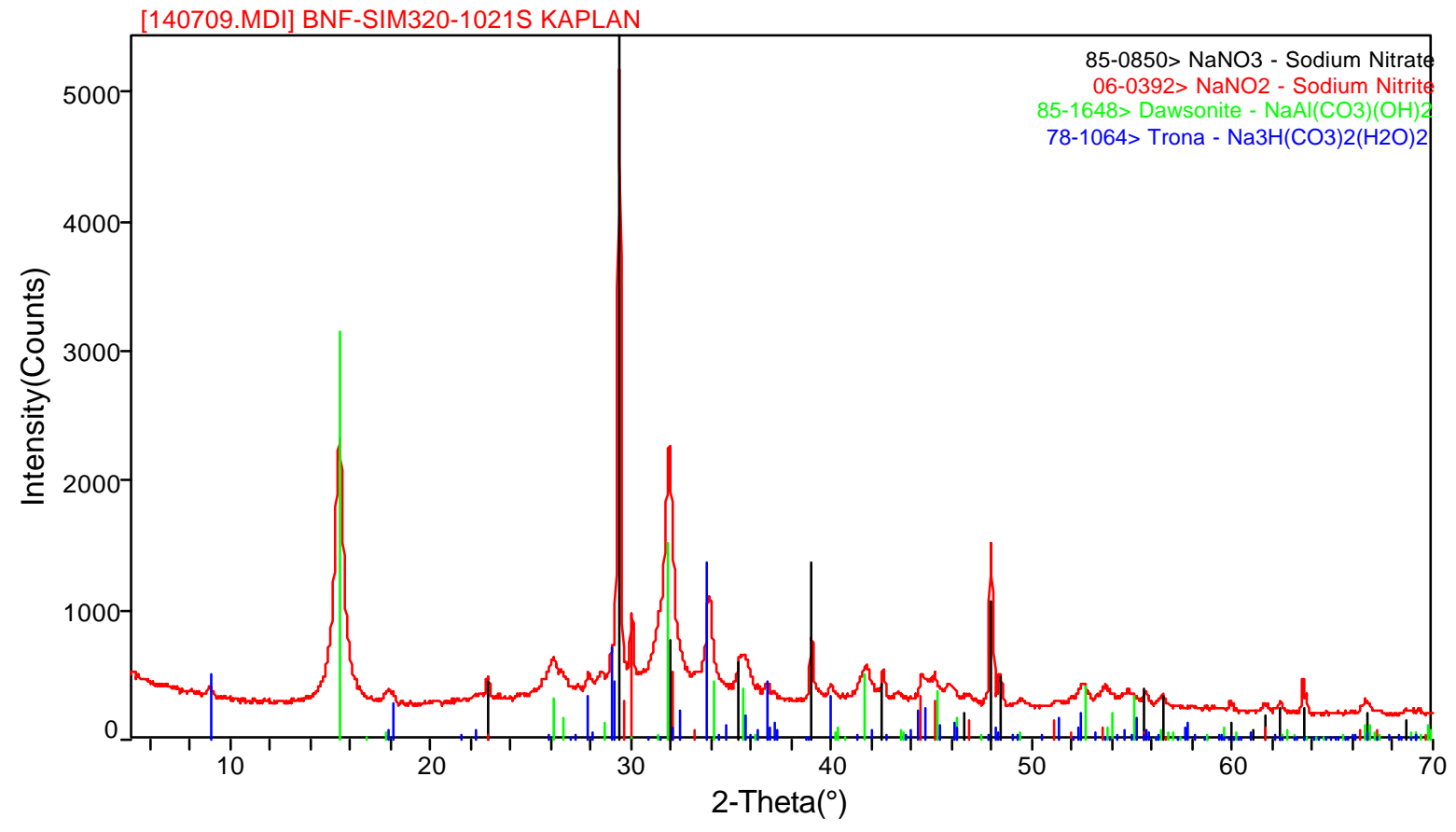


Figure B3. XRD Spectrum of Solids from 50\% AZ-101 / 50\% AN-107.

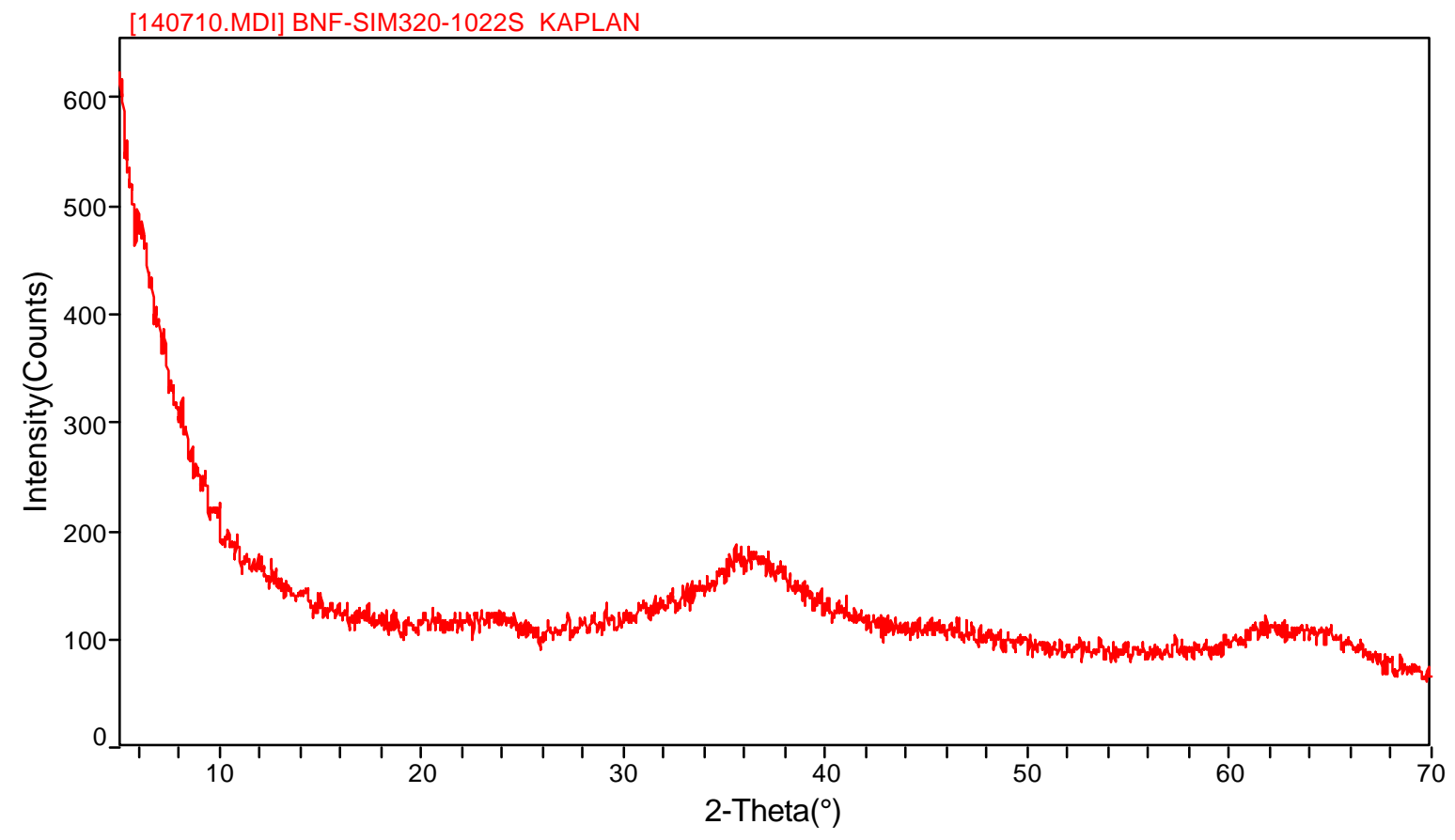


Figure B4. XRD Spectrum of Solids from 10\% AN-107 / 90\% AN-104.

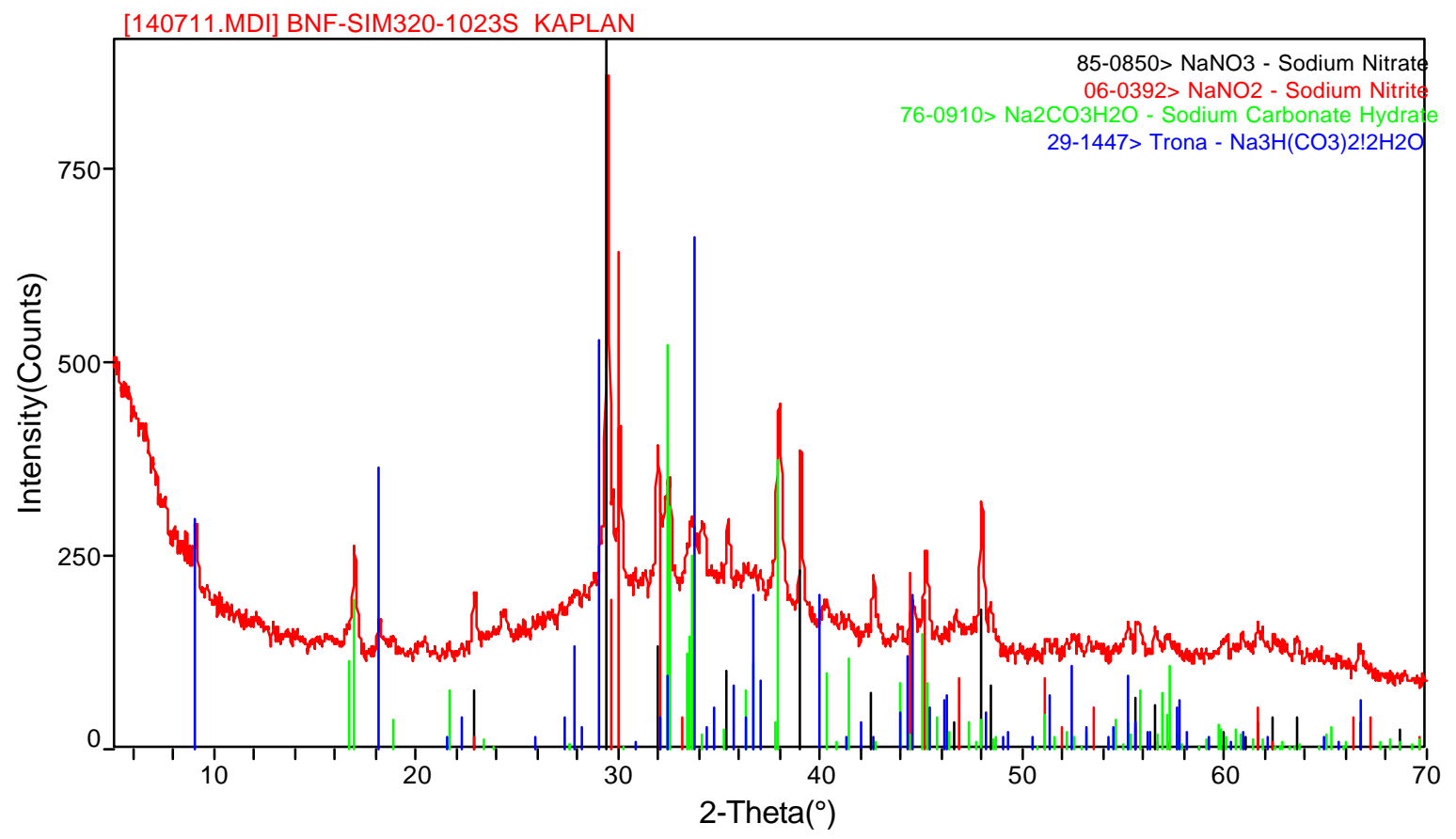


Figure B5. XRD Spectrum of Solids from 50\% AN-107 / 50\% AN-104.

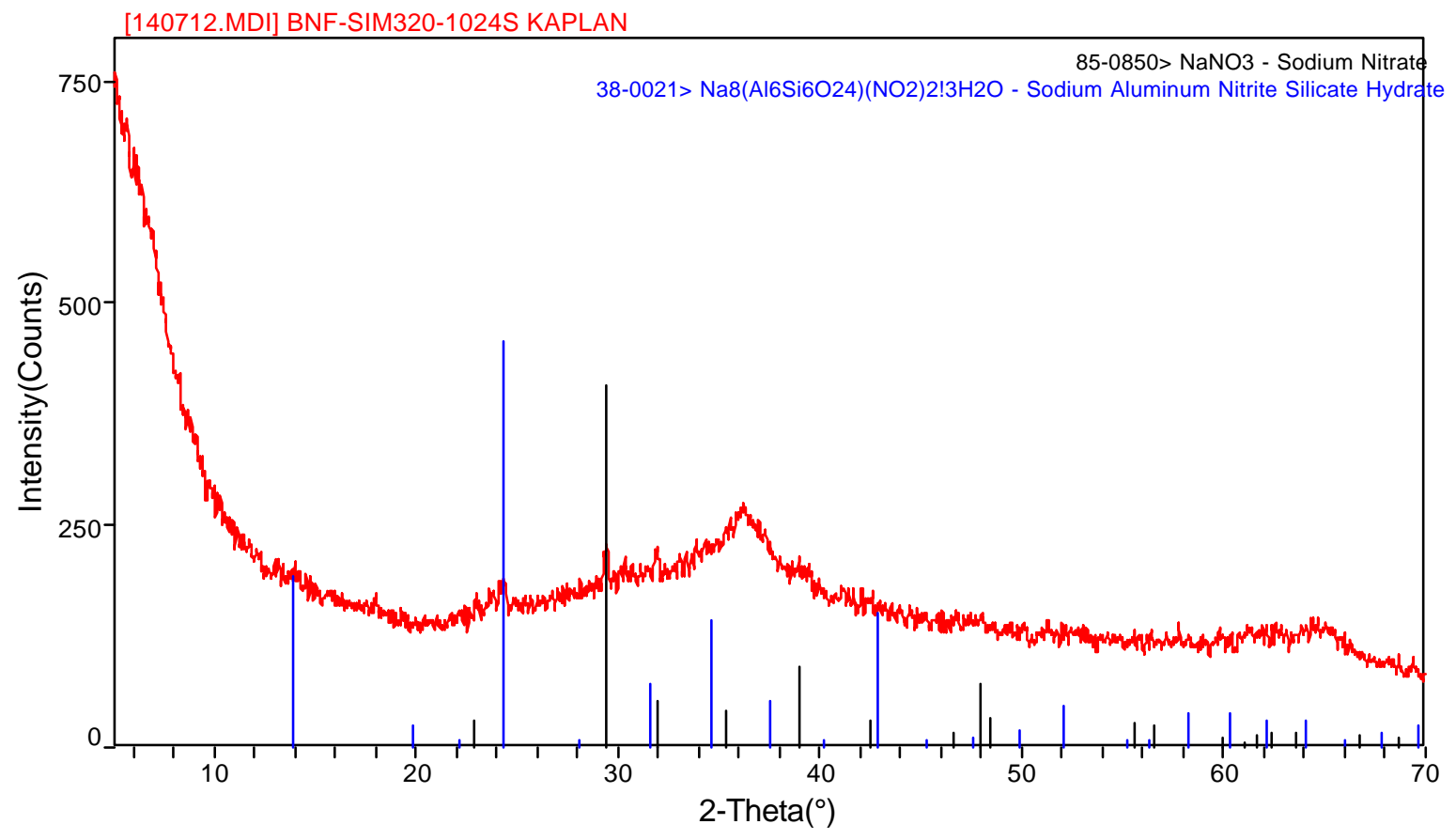


Figure B6. XRD Spectrum of Solids from 9\% dilute AN-107 / 91\% AN-104.

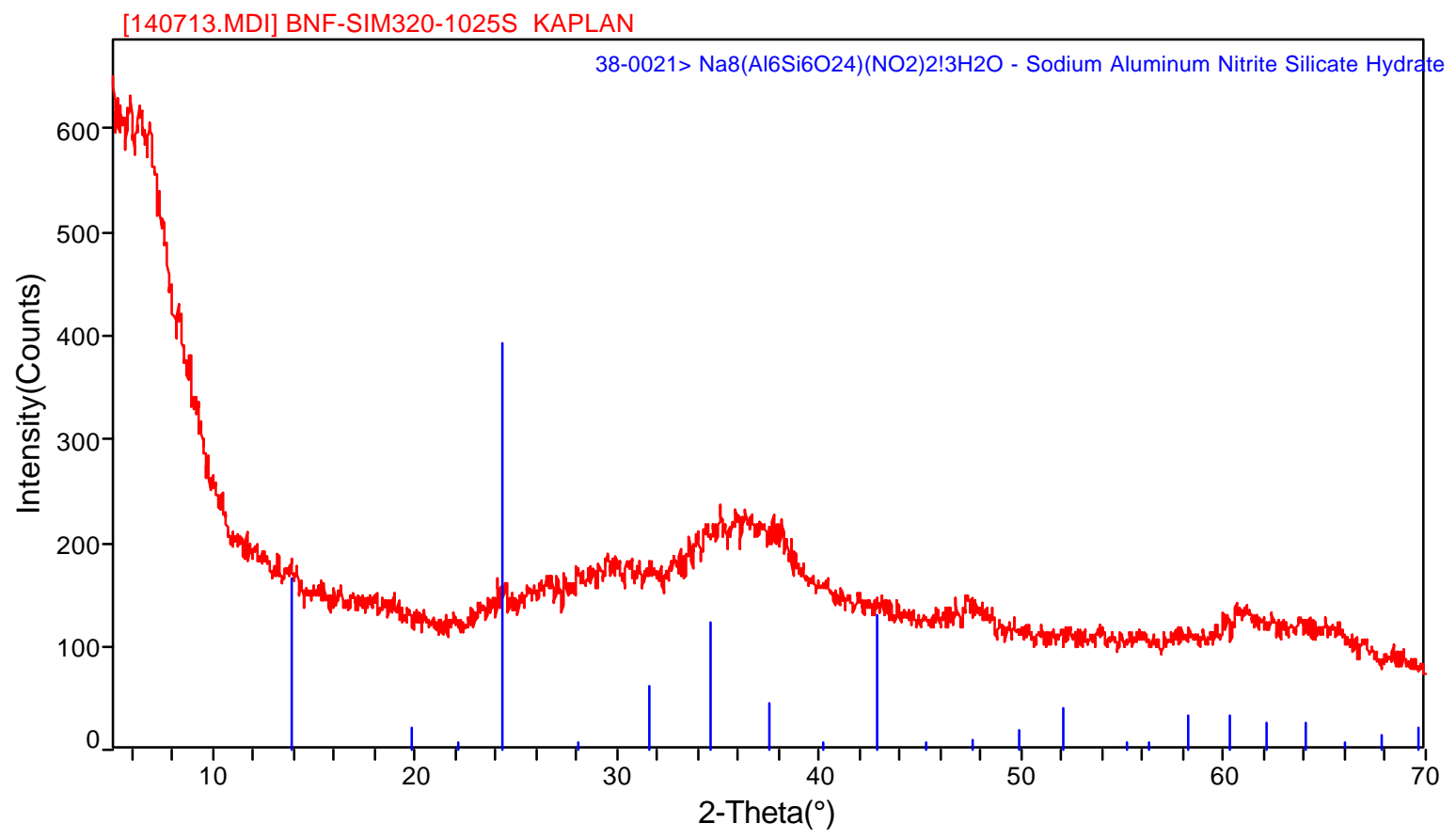


Figure B7. XRD Spectrum of Solids from 9\% dilute AN-107 / 91\% AW-101.

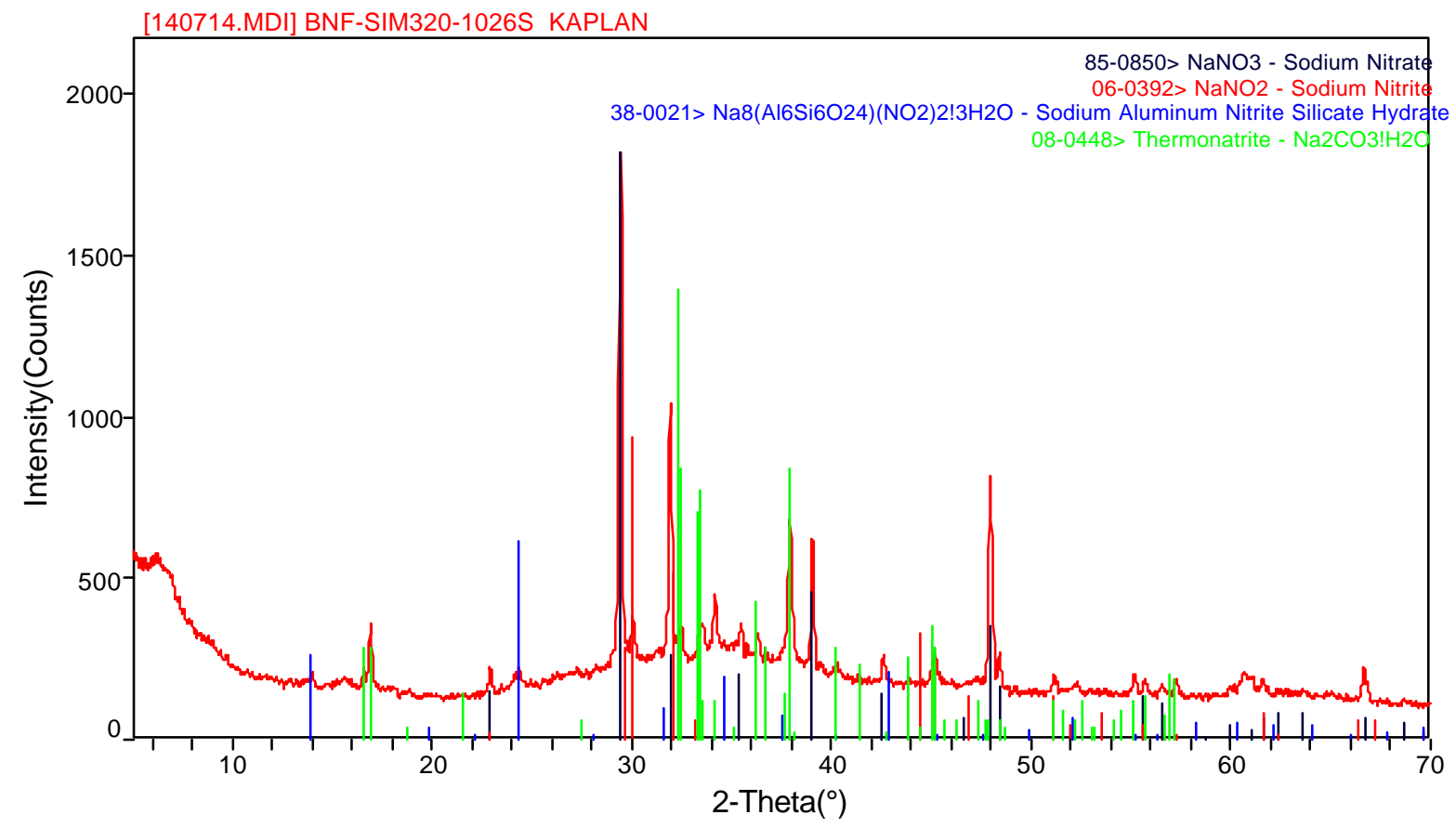


Figure B8. XRD Spectrum of Solids from 9\% dilute AN-107 / 91\% AZ-102.

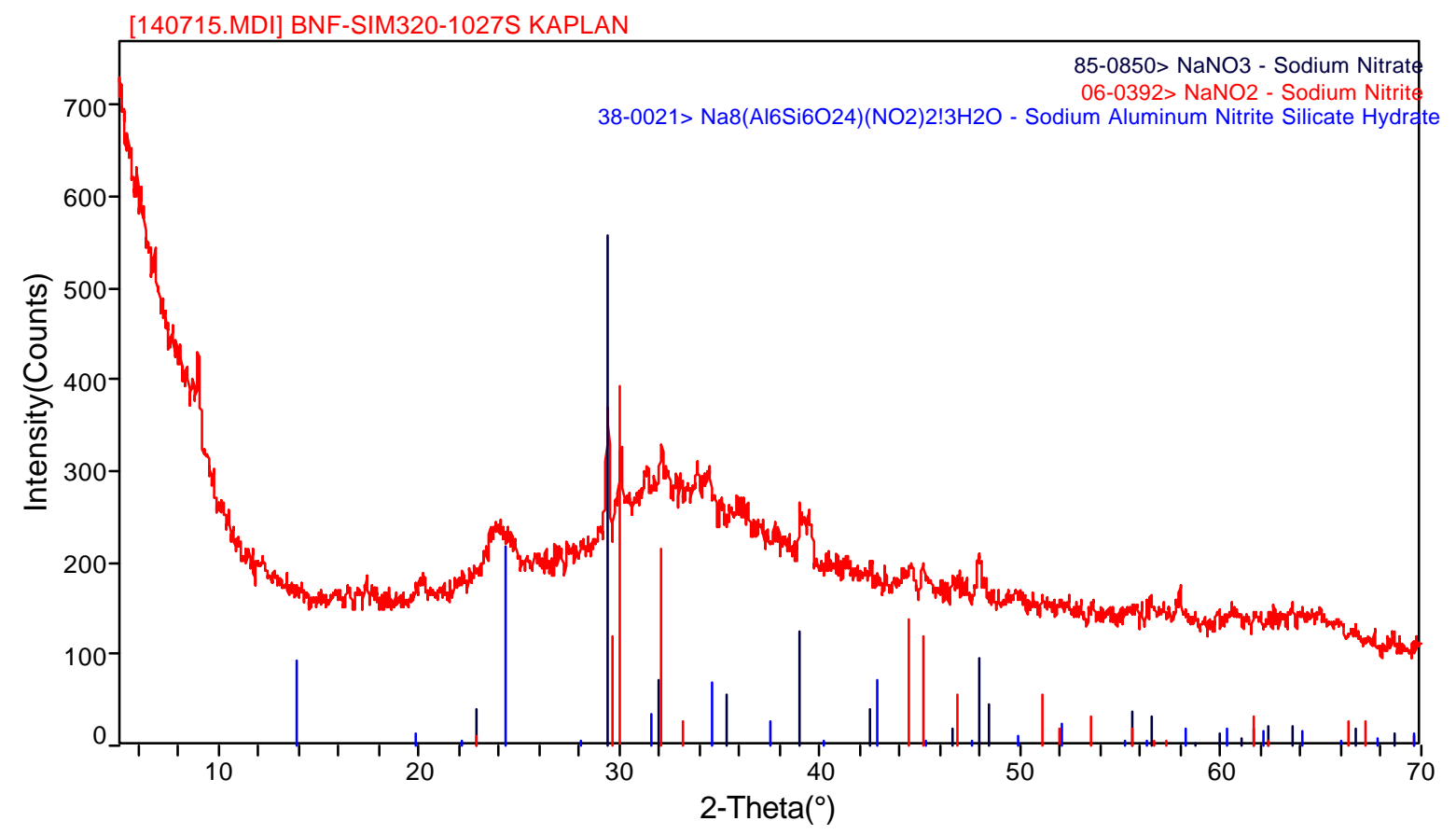


Figure B9. XRD Spectrum of Solids from 9\% dilute AN-107 / 91\% AN-104.

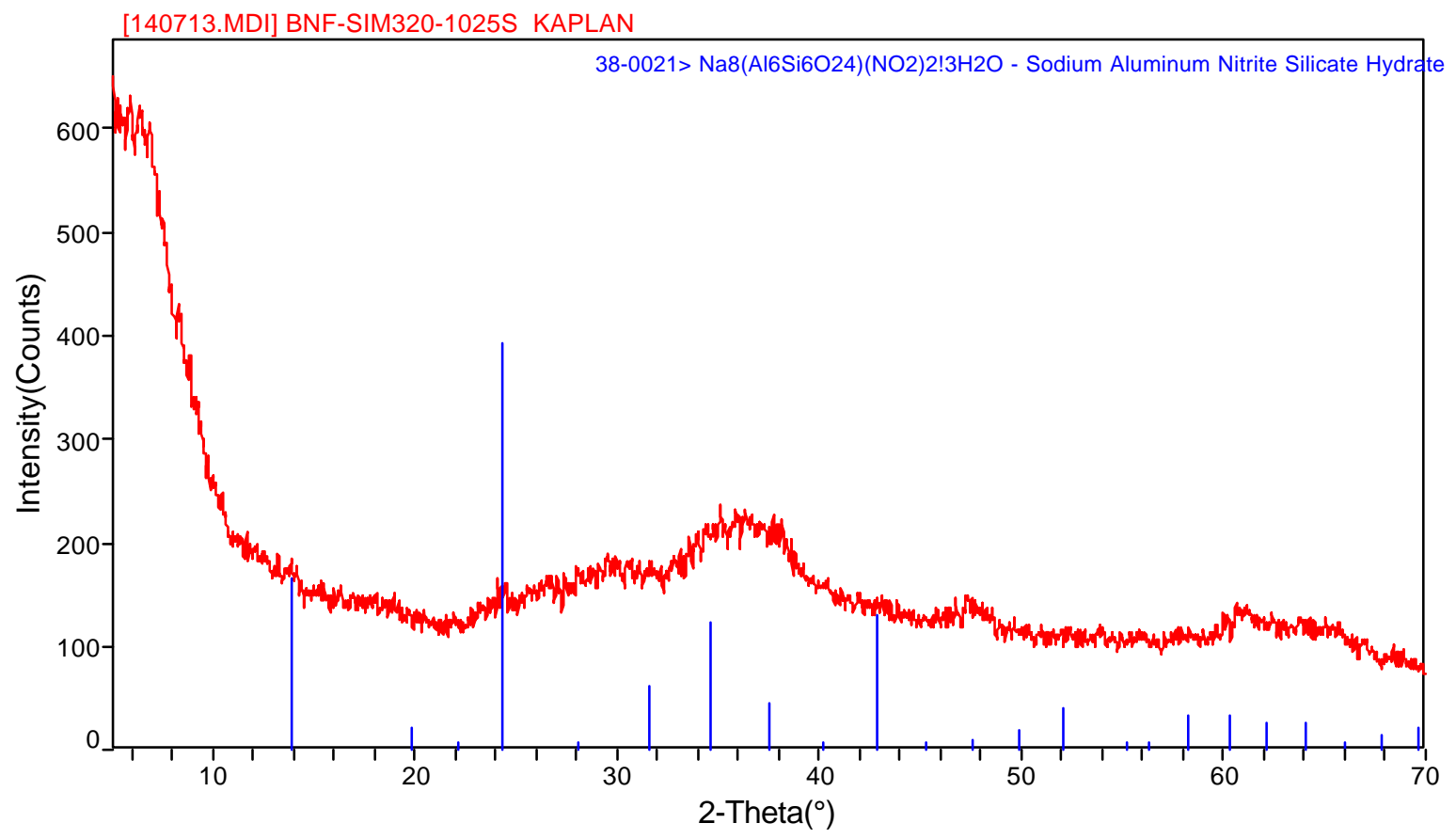


Figure B10. XRD Spectrum of Solids from 9\% dilute AN-107 / 91\% AW-101.

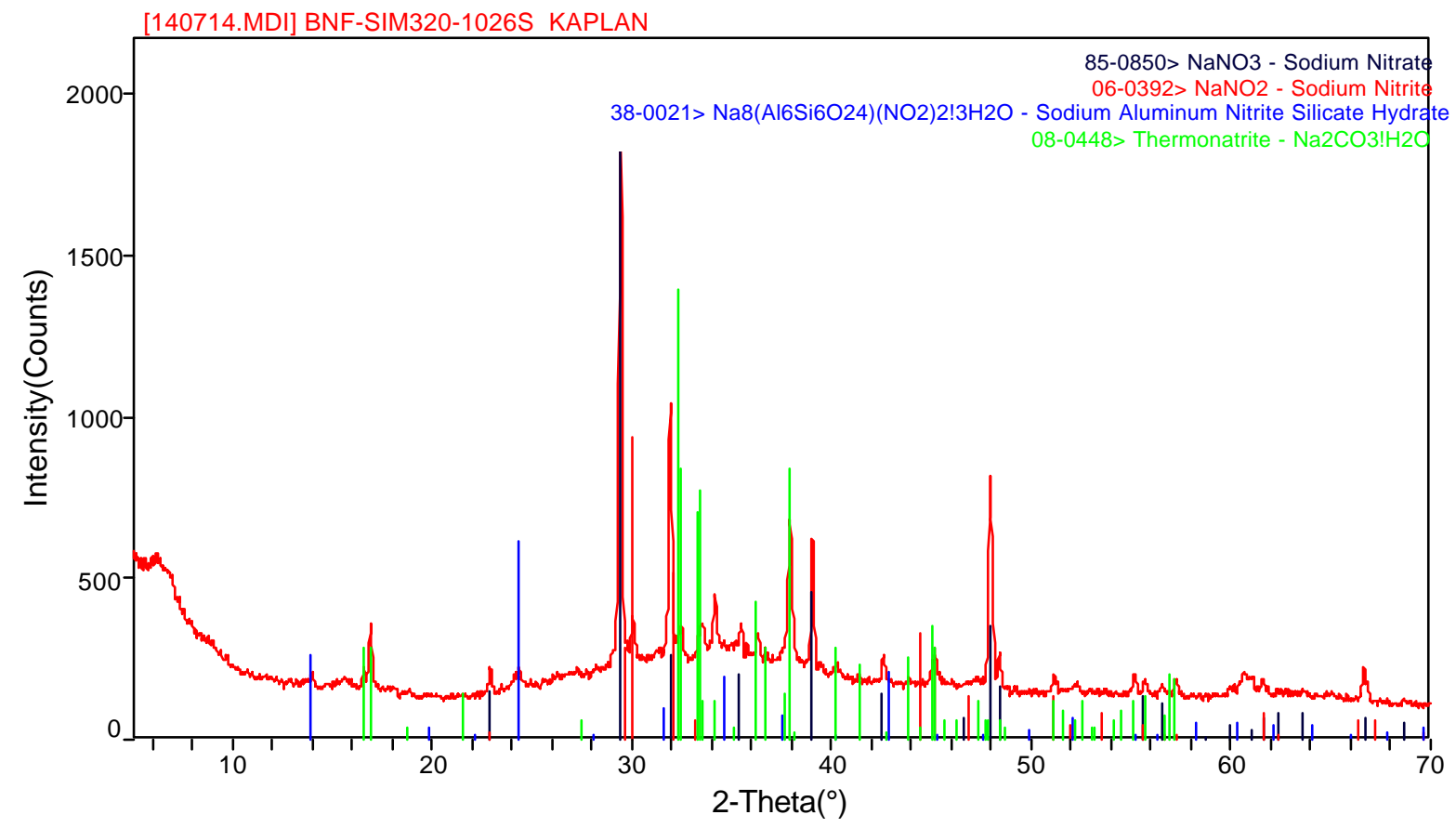


Figure B11. XRD Spectrum of Solids from 9\% dilute AN-107 / 91\% AZ-102.

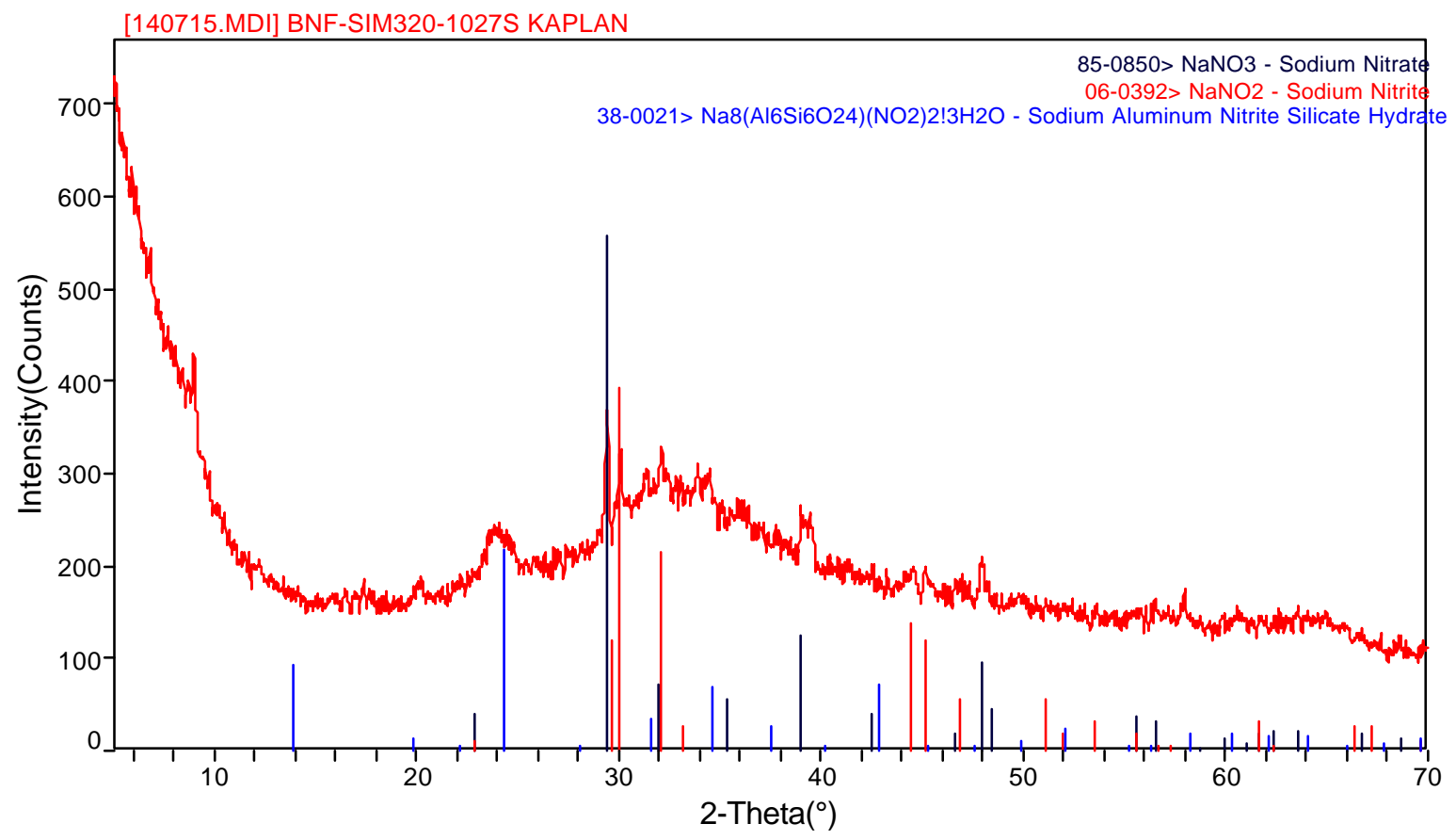


Figure B12. XRD Spectrum of Tabular Crystals from AN-107 Simulant Feed.

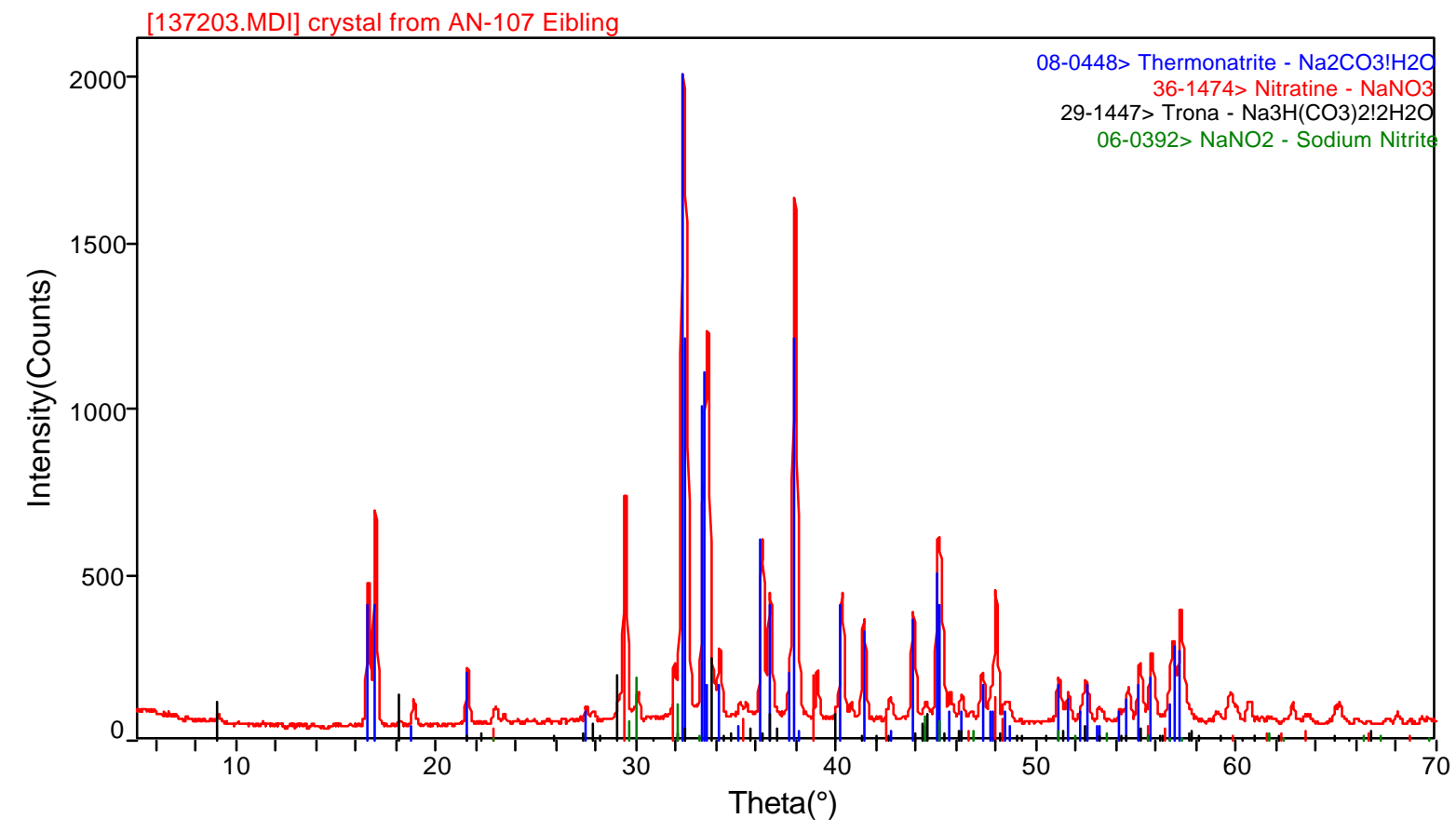


Figure B13. XRD Spectrum of Solids from pH 10 Adjusted AN-107 Simulant.

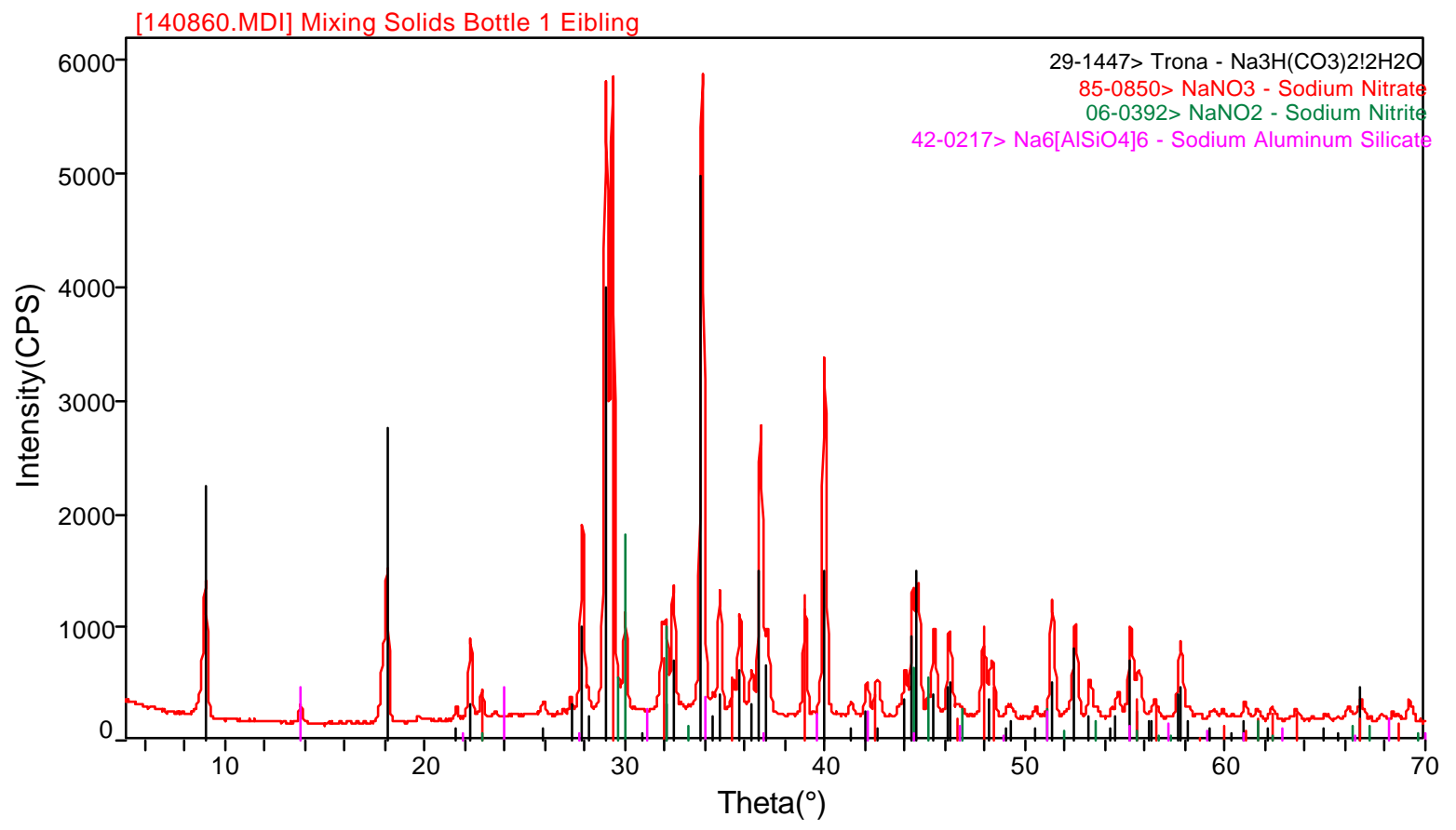


Figure B14. XRD Spectrum of Solids from pH 14.5 Adjusted AN-107 Simulant.

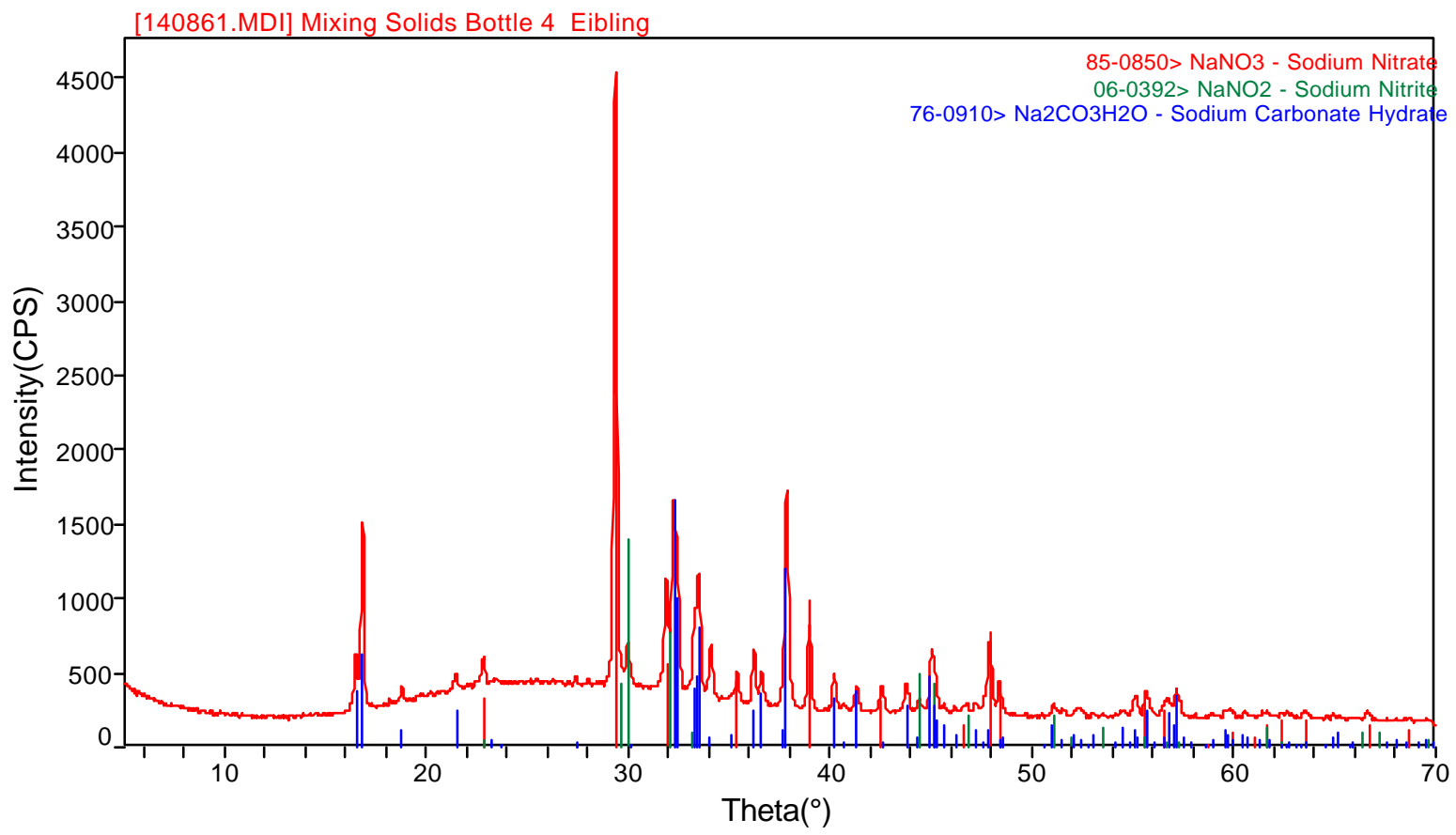


Figure B15. XRD Spectrum of Solids from pH 10 Adjusted AN-104 Simulant.

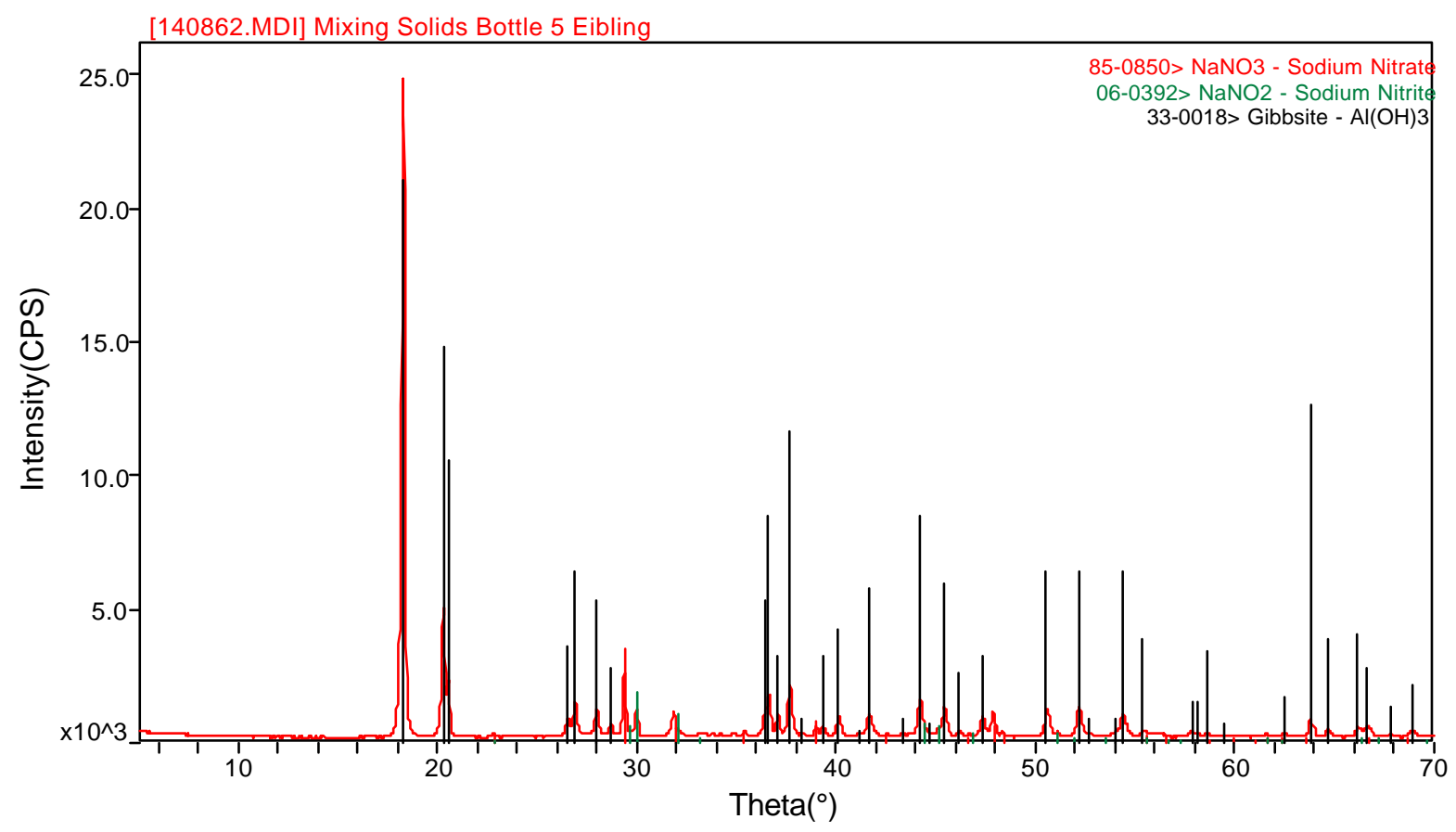


Figure B16. XRD Spectrum of Solids from pH 10 Adjusted AW-101 Simulant.

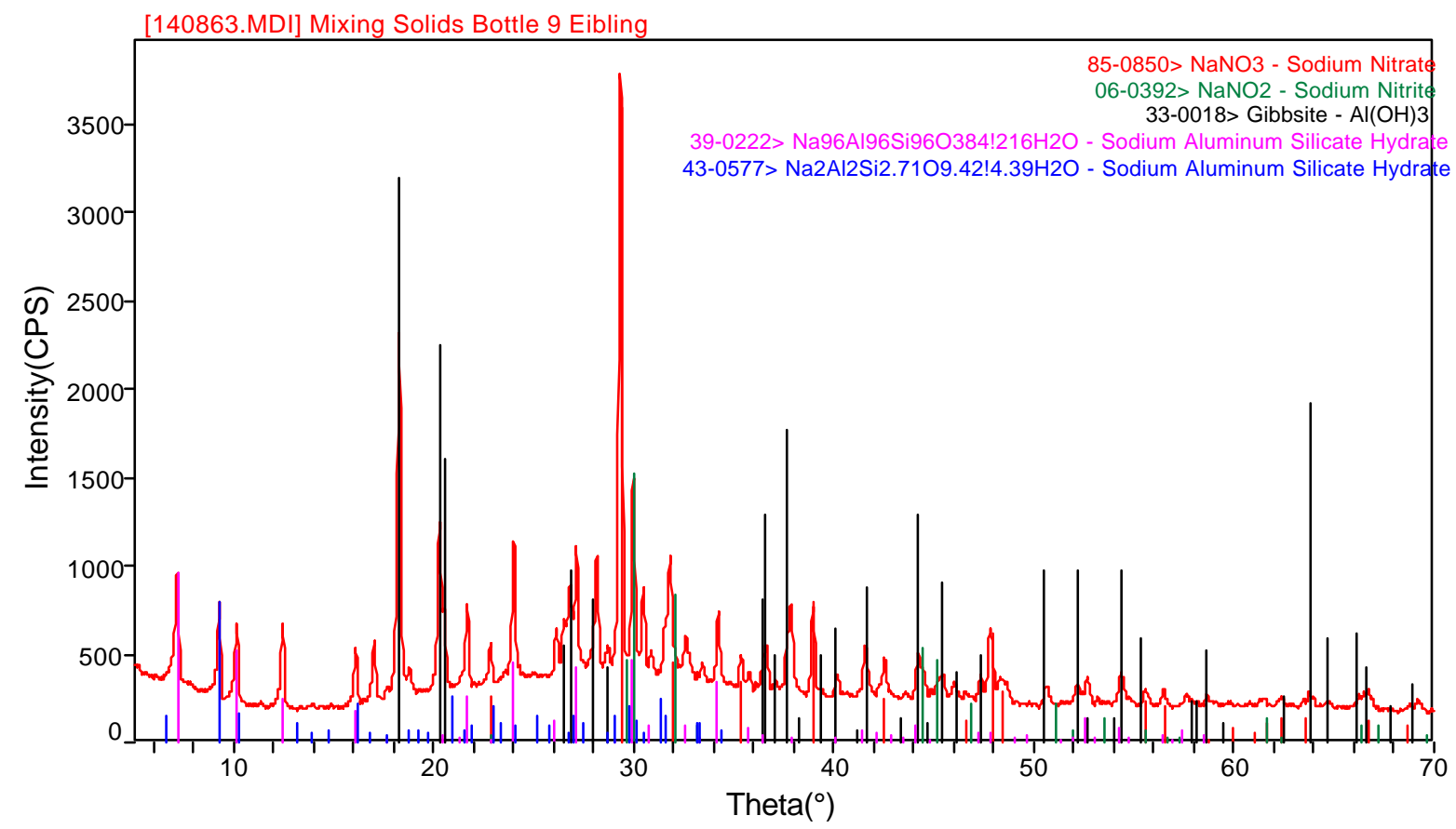


Figure B17. XRD Spectrum of Solids from pH 10 adjusted AZ-101 Simulant.

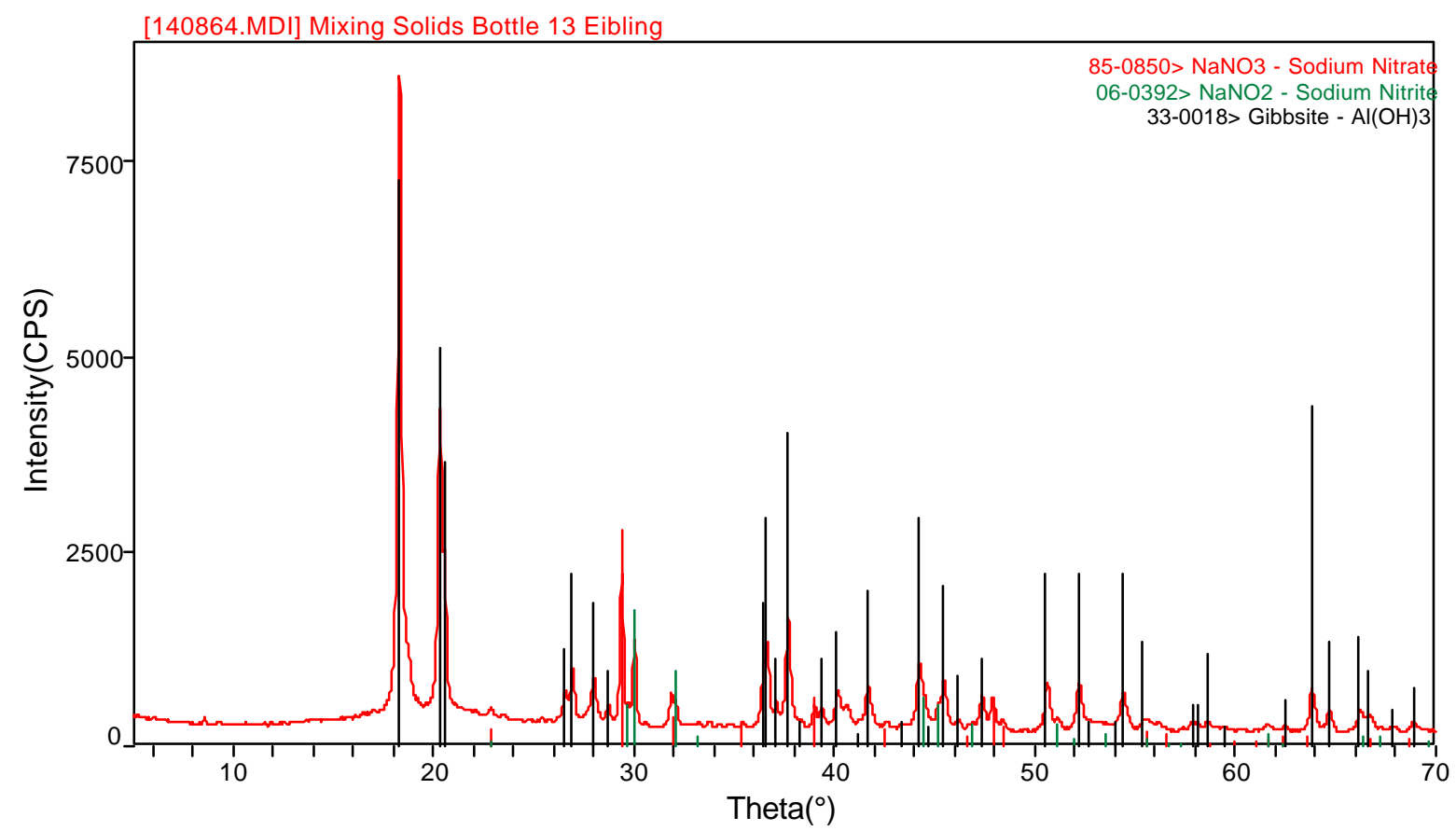


Figure B18. XRD Spectrum of Solids from pH 11 Adjusted AZ-102 Simulant.

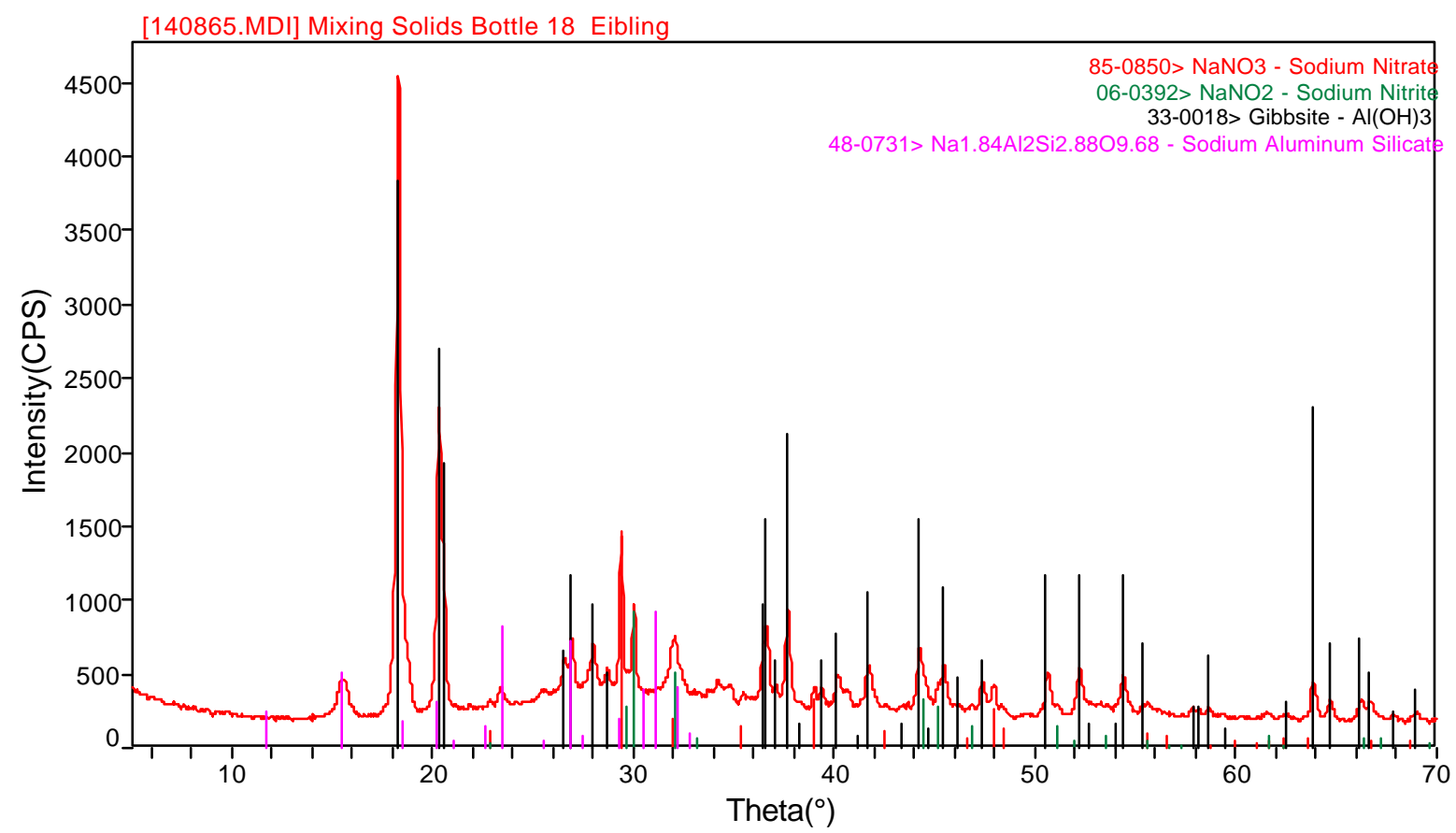


Figure B19. XRD Spectrum of Solids from 50\% AN-107 and 50\% C-106 Caustic Leachate.

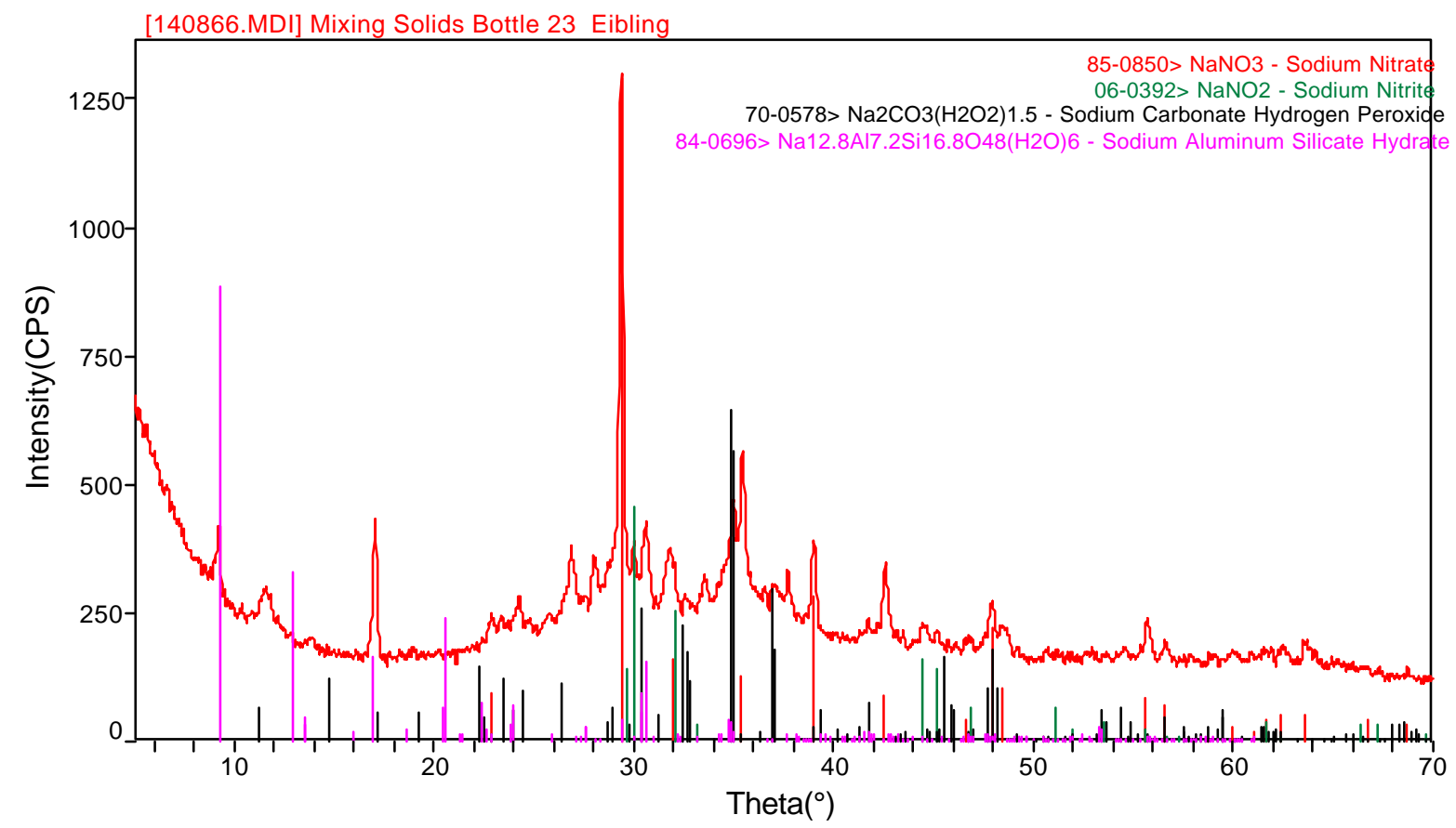




\title{
8. DISTRIBUTION
}

\author{
M. E. Johnson, CH2M Hill Hanford Group \\ RPP file, T. Baxter, 773A \\ R. E. Eibling, 704-1T \\ D. I. Kaplan 773A \\ D. J. McCabe 773-42A \\ H. F. Sturm, 773-A \\ S. T. Wach, 773-42A \\ D. D. Walker, 773A
}

